


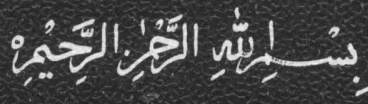

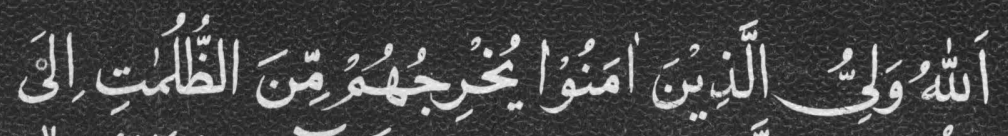

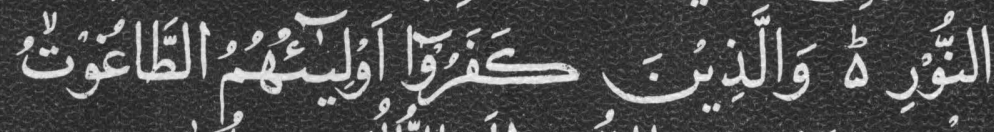

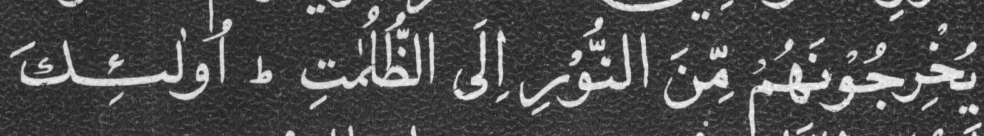

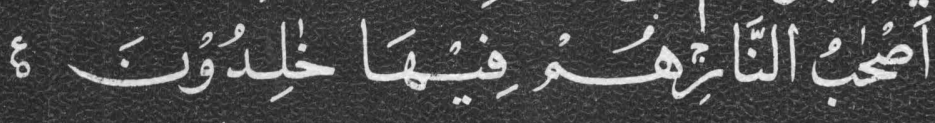

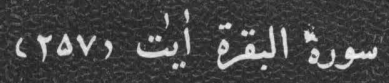

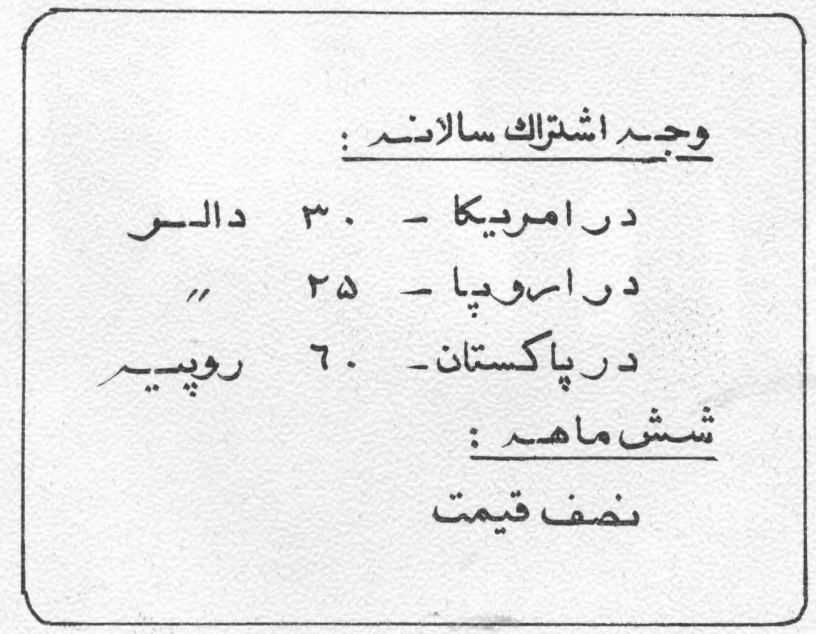

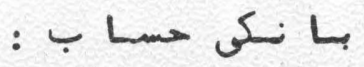

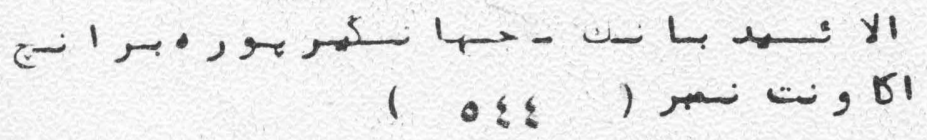




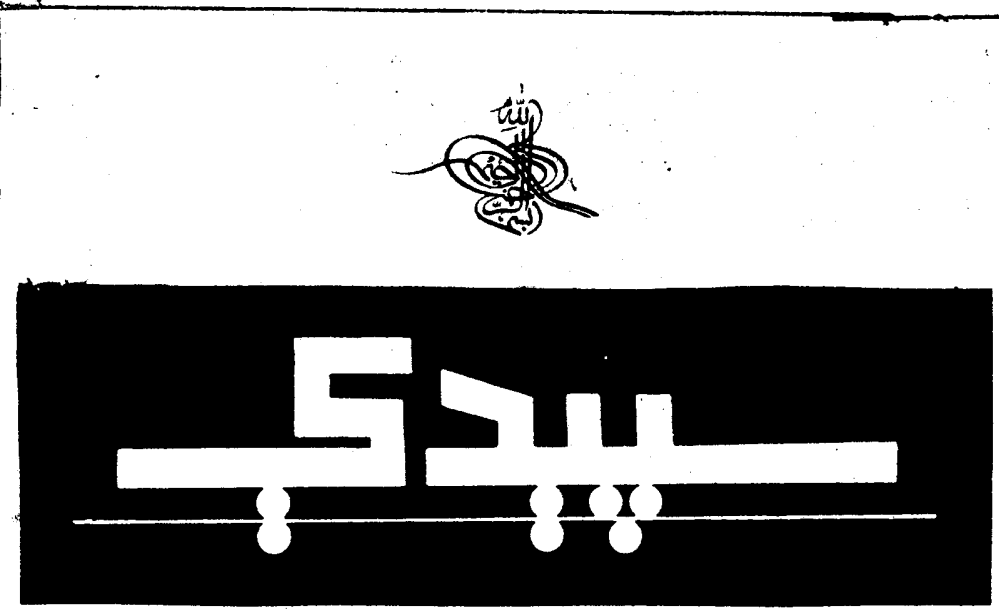

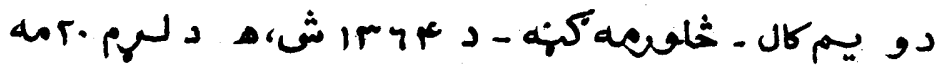

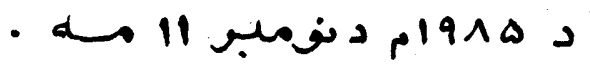

$$
\begin{aligned}
& \text { جلونئك : } \\
& \text { محتّهديق-يسرلك }
\end{aligned}
$$

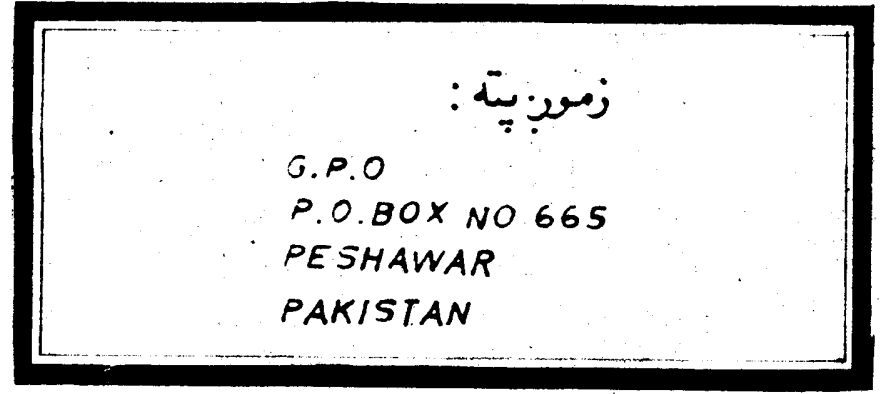




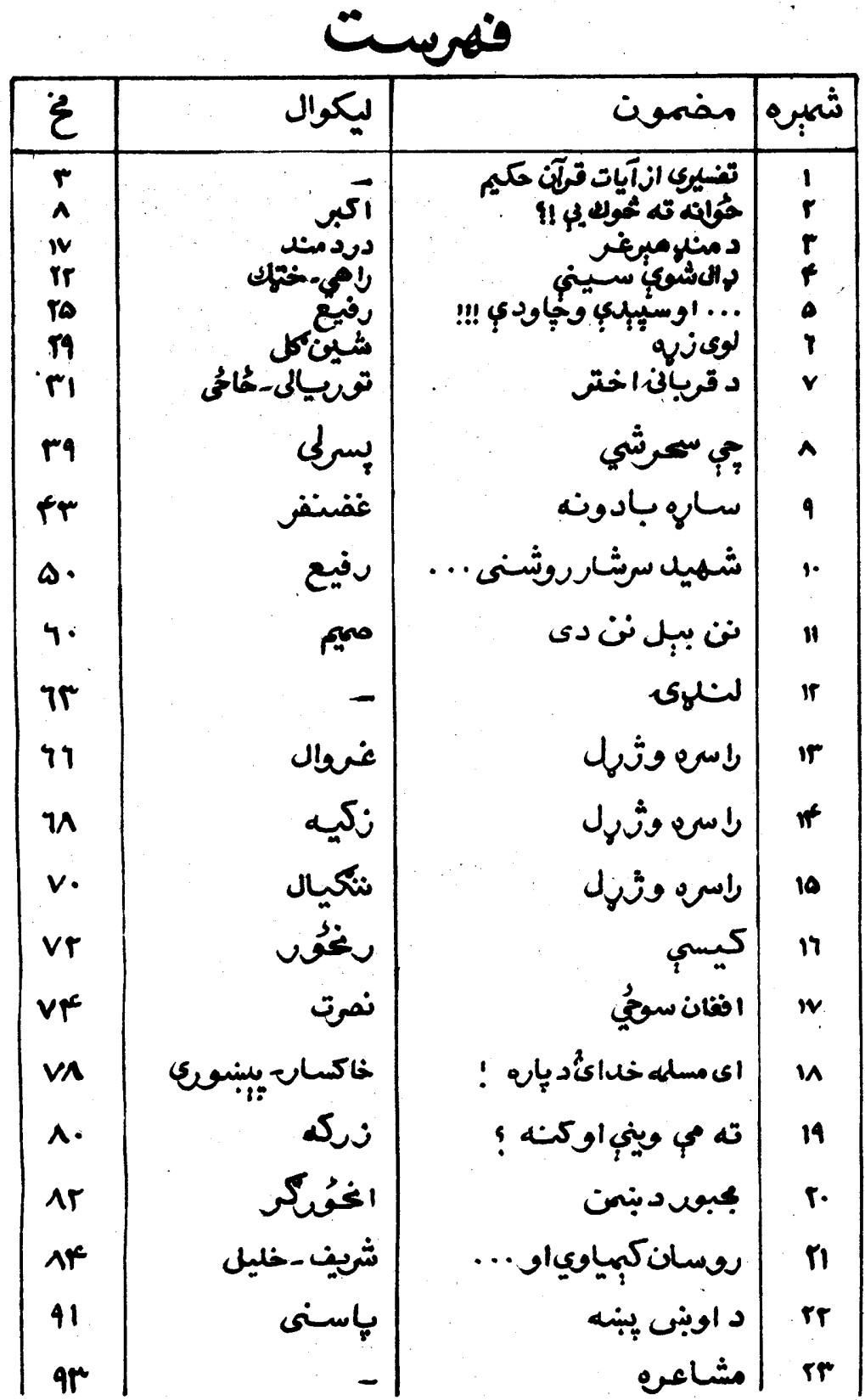




\section{تفنيري ازآيات قرآنحكيم}

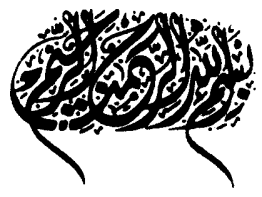

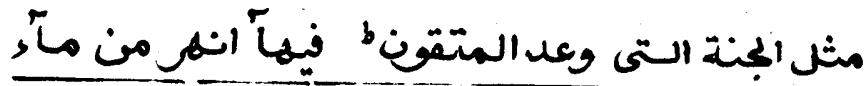

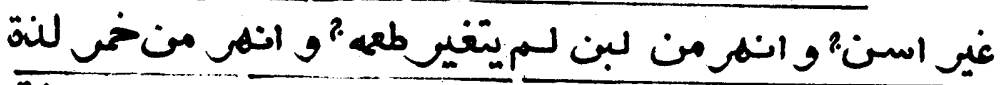

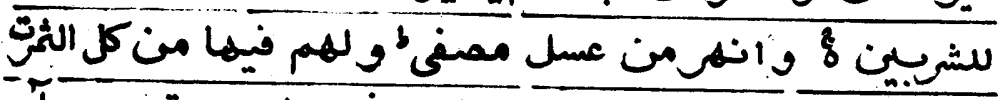

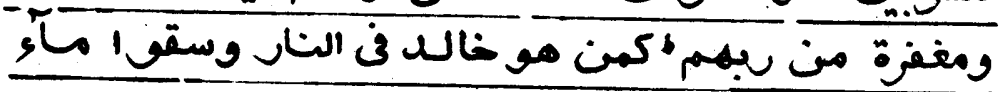

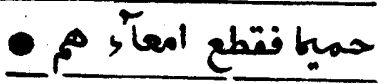

(10 : (10)

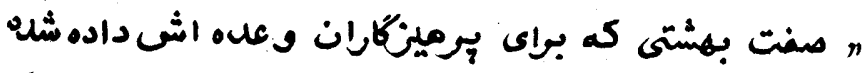

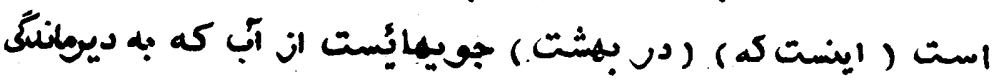

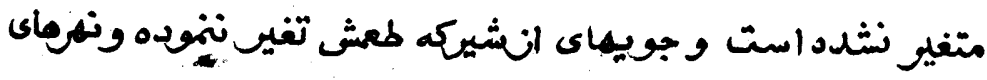

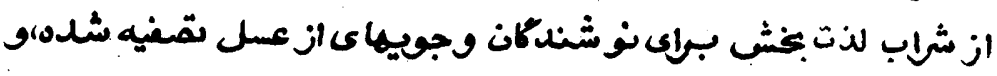


ايشانرا ست أنجا مر نوع ميوه وأمسنش بـوردكار شان."،

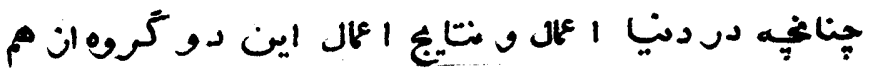

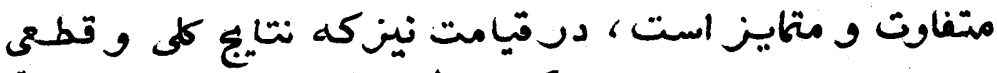

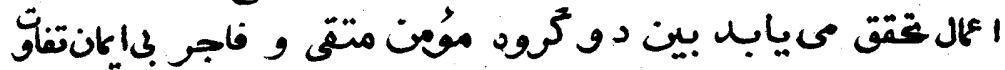

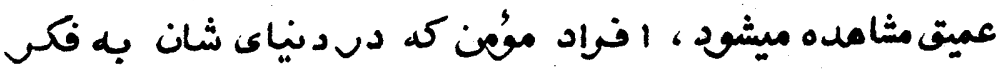

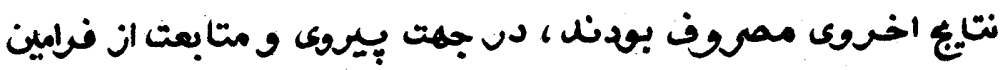

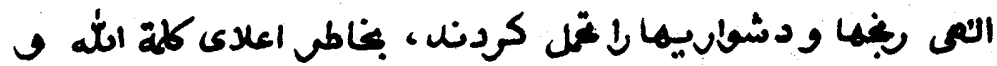

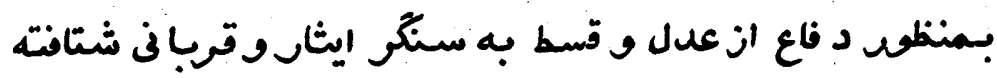

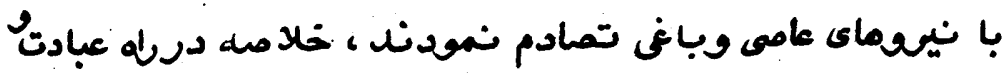

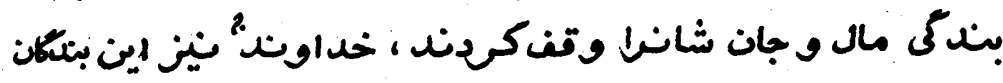

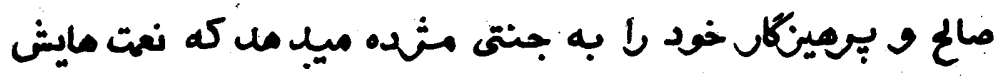

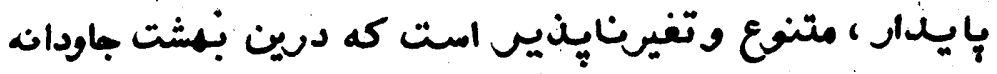

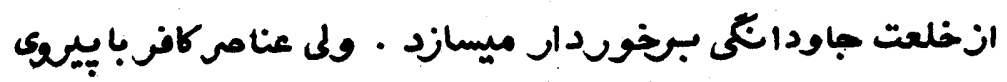

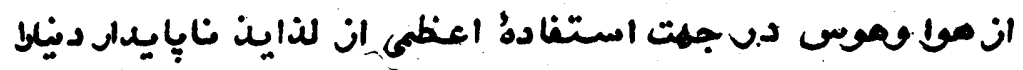

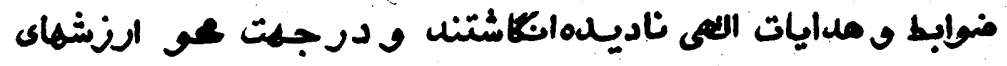

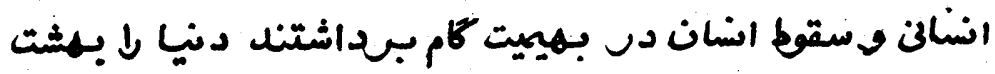

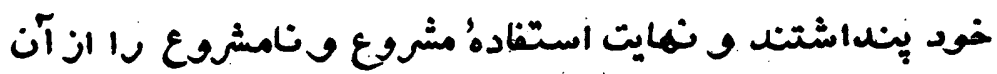

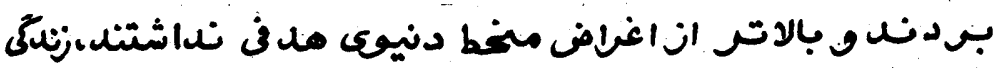

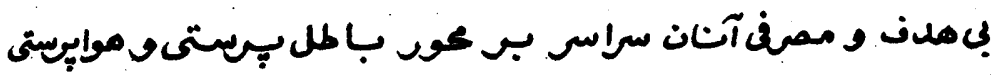

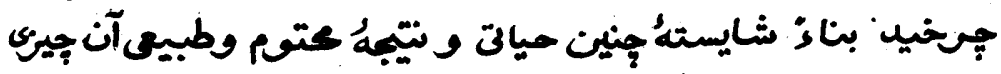

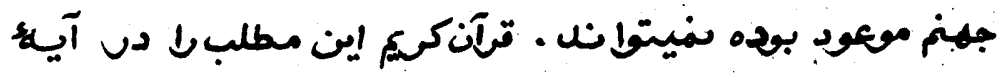


تغسيري انز...

a

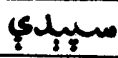

ديكرعا هنين توضيع ميكند :

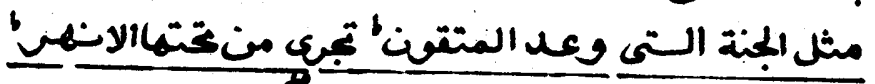

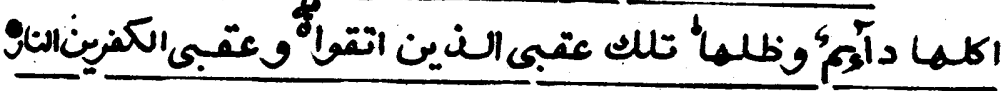

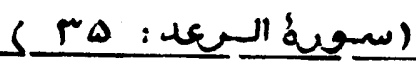

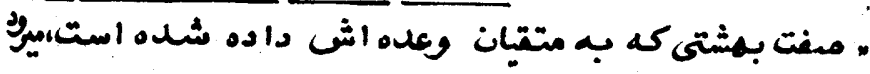

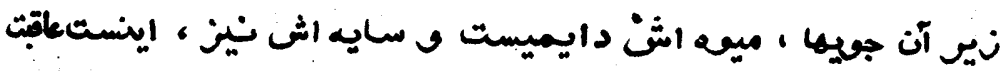

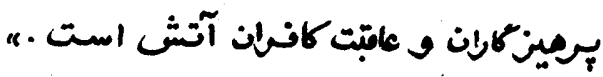

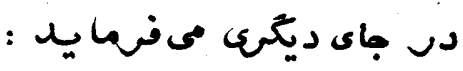

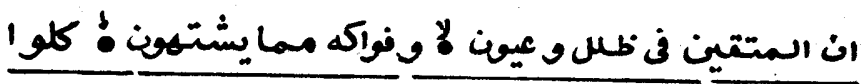

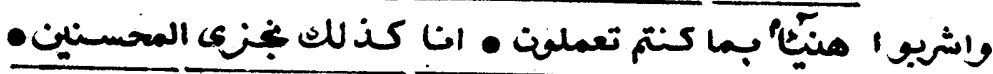

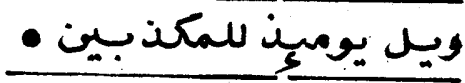

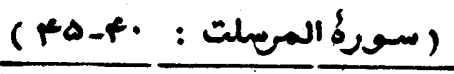

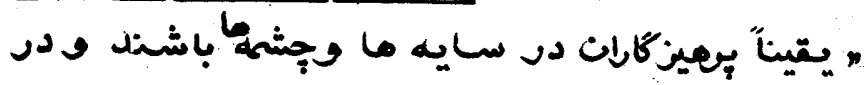

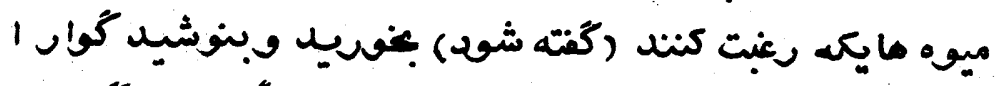

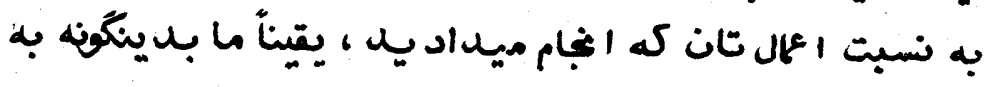

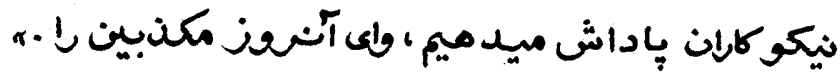

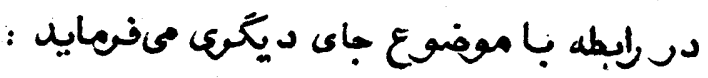

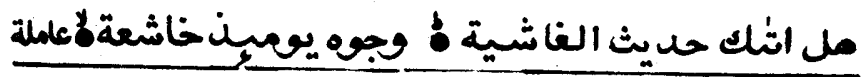

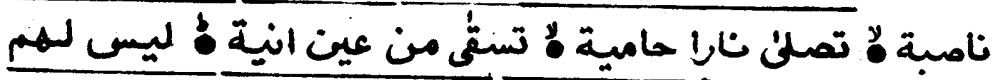

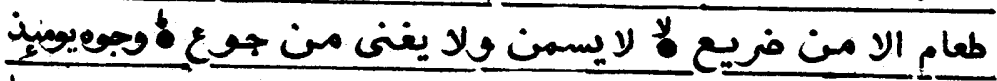

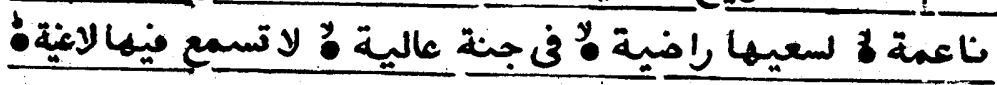




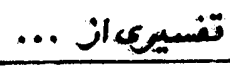

1

سبِيدي

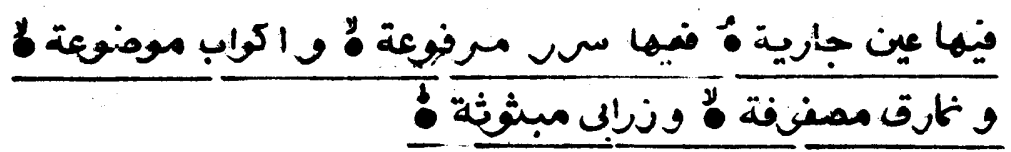

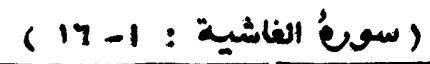

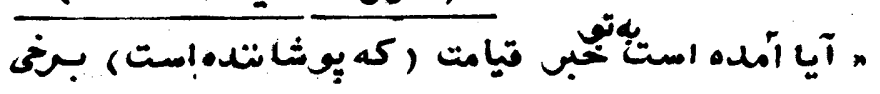

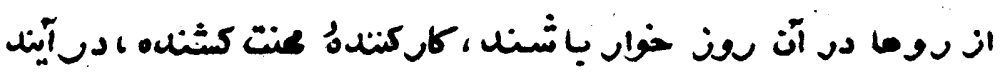

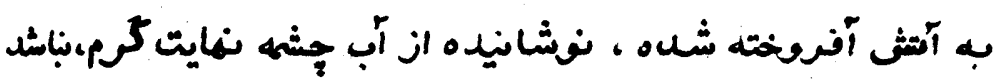

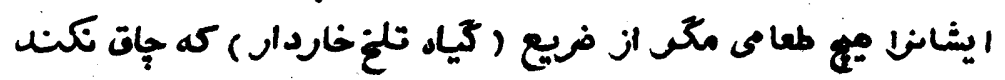

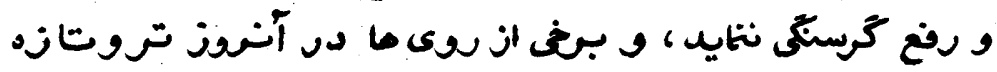

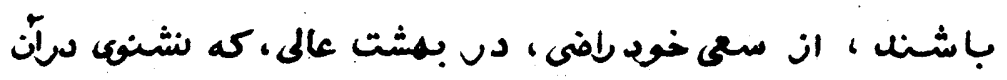

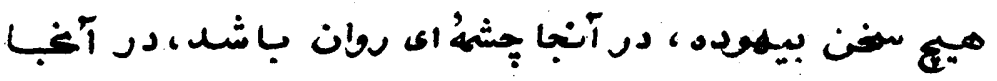

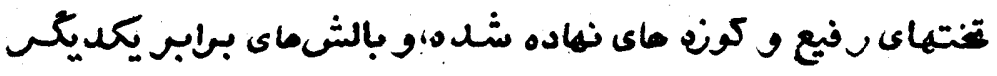

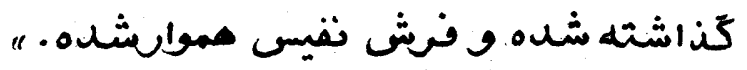

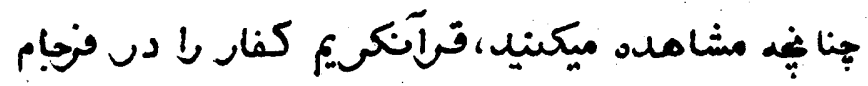

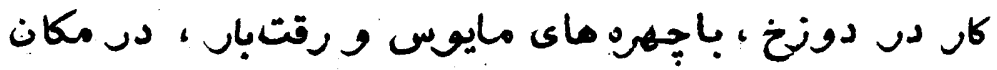

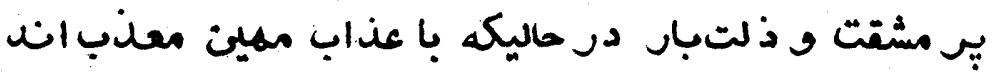

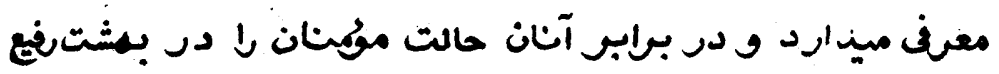

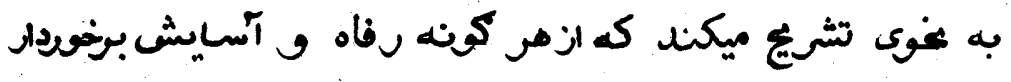

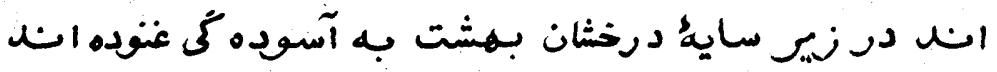

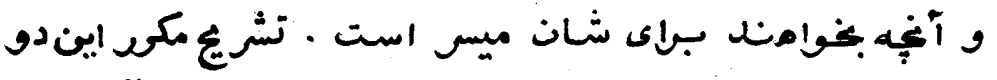

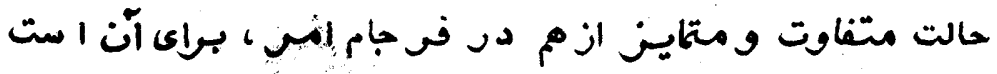

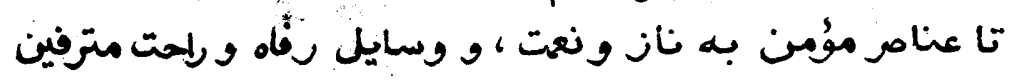




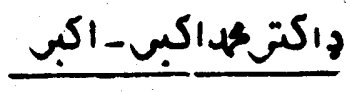

حُوانه ته خوكي يبه

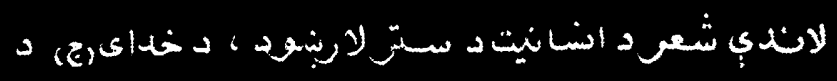

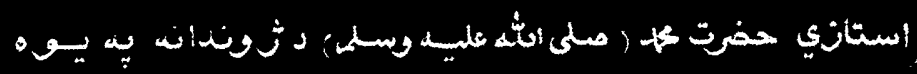

$\circ$

.

$$
\begin{aligned}
& \text { حُوانه، ته خُوك بي !? } \\
& \text { د ستصدو لاندي }
\end{aligned}
$$

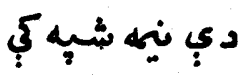

$$
\begin{aligned}
& \text { : }
\end{aligned}
$$

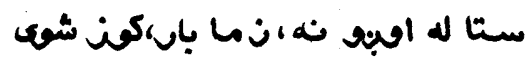

$$
\begin{aligned}
& \text { او هنd بار كن كى } \\
& \text { - * } \\
& \text { بال د زئ بونه } \\
& \text { د كالو ينه - زئ دئ }
\end{aligned}
$$




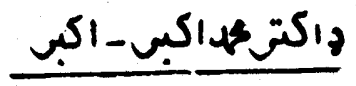

\section{حُوانه ته خوكي يج}

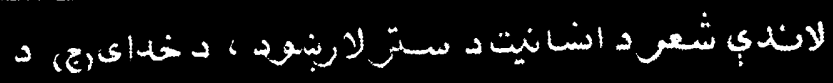

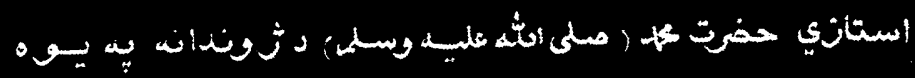

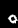

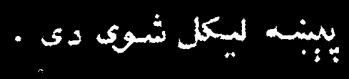

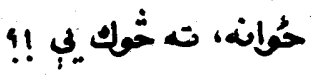

$$
\begin{aligned}
& \text { د ستحفو لاندي! }
\end{aligned}
$$

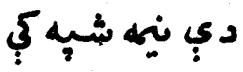

: ستا له اقيق نه ، نما بانككن شعى

$$
\begin{aligned}
& \text { او مغه بار كن كم } \\
& +4 \\
& \text { بال د زيج بو ه ه }
\end{aligned}
$$

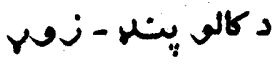




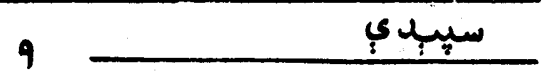

كه د عمر مدوستتني كلونه

كابِه لوني

يو د اوبوكنله

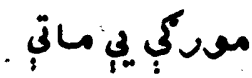

كه بيجلا سو تنته

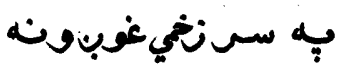

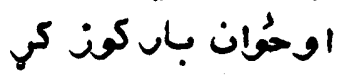

*

د مغه تلو د ي ينّو

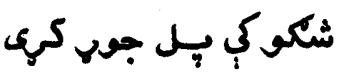

او : الواددوبي له

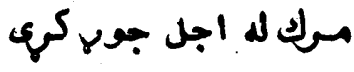

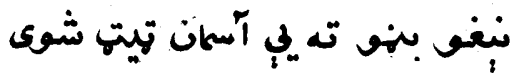

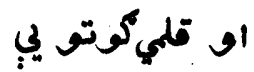

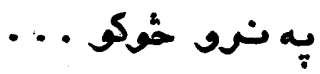

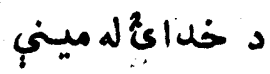

يه خداى"مينف له انذل جور كيع

* *

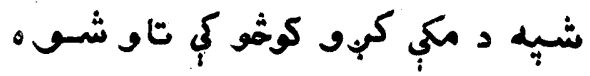

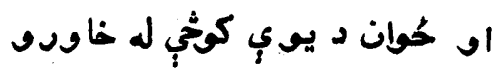

د بنسل آسمان ته كتل دي كوي 
د مسلك لد خلا صو كركى د سبّون كرمب رنا كم ميا د حيانا كى يبغلف د دبوالونف د تنو له مإِده كنو كو كُ كون د جانان ته كتل

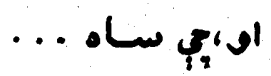

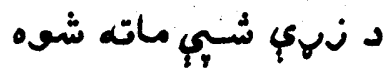

$$
\text { : }
$$

يع ساه مانج بنى

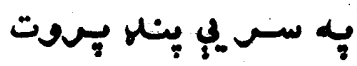

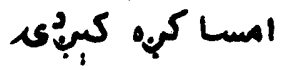

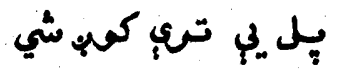

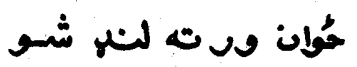

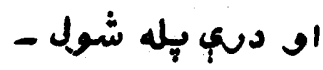

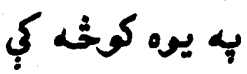
دني قل مونه شّو

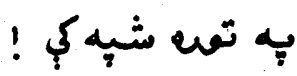
د امس ته تلك د بحم هيل دمأن كامونه 


\section{او دكامونف آوان}

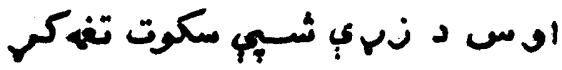
مُمان، بوعى ويبوينتّله " مورب :

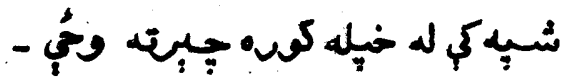

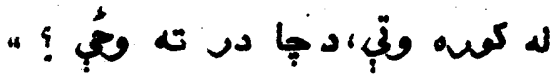

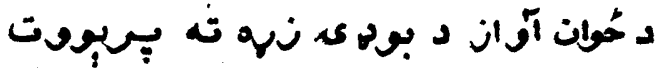

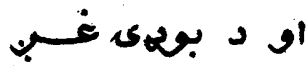

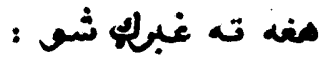

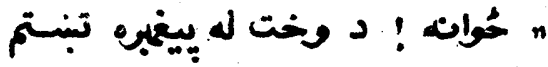

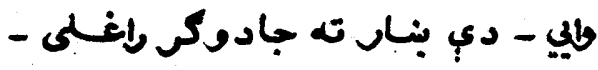
جادى به نهونف بئي د مغه تانده حمُإي

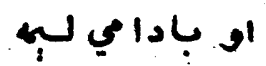

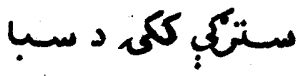
اق مـابنا مي ورينـا

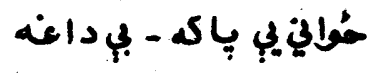

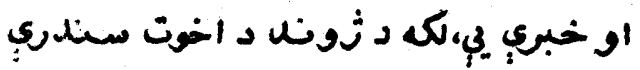

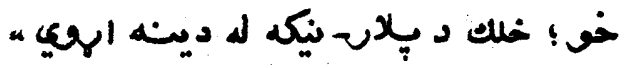

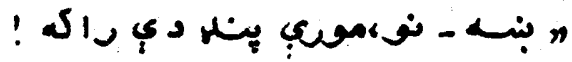

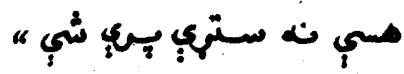




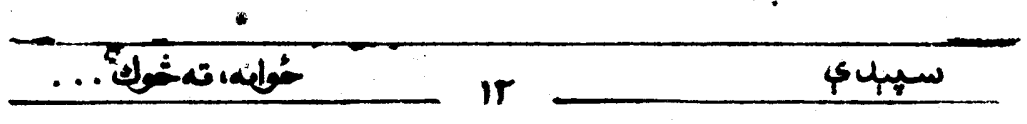

$$
\begin{aligned}
& \text { بوخ د بومدى احساس } \\
& \text { دمُهنة أومان } \\
& \text { مانته نغه كي } \\
& \text { او دكامونف بنـكالو }
\end{aligned}
$$

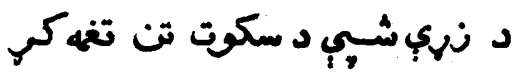

$$
\begin{aligned}
& \text { نو : به يق كوثه كي }
\end{aligned}
$$

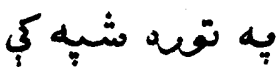

دري ثدمونه، يو شطل :

$$
\text { د امسا تك }
$$

$$
\text { د بونهى بِل }
$$

د حُوان كامونه

او د دكامقف بنككالو

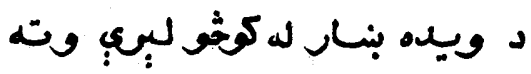

$$
\text { او له بناره لبعئ }
$$

د سهوف شُكو تل بكي

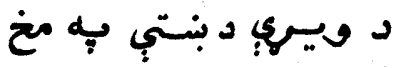
د ثدوند بنكالو شهص دئي

* * *

$$
\begin{aligned}
& \text { بولهى يو بينه مدوكي } \\
& \text { جإجى - بإنج } \\
& \text { بنّل - بـن بالن }
\end{aligned}
$$




$$
\text { مLاهم }
$$

$$
\text { دخولي ترخب لاهي }
$$

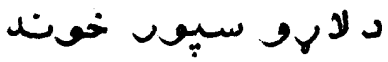

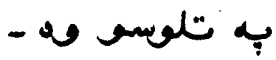

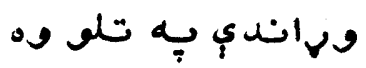

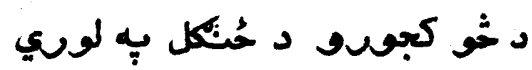

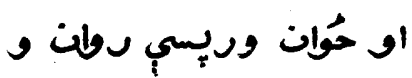

$$
\begin{aligned}
& \text { كه د ثرد }
\end{aligned}
$$

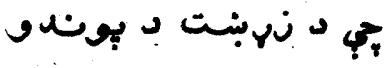

$$
\begin{aligned}
& \text { يل ... }
\end{aligned}
$$

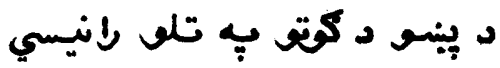

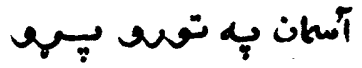

$$
\begin{aligned}
& \text { بونثلى كت و }
\end{aligned}
$$

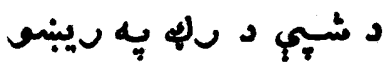

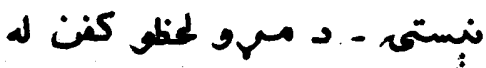

كن تور تَكىن وركرل

$$
+4
$$

يون د كجوب! ونه

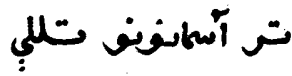

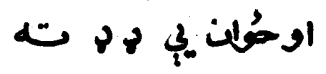

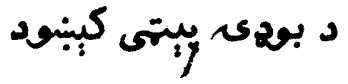




$$
\begin{aligned}
& \text {... } \\
& \text { يو - دمه دربه } \\
& \text { كو موسناكه } \\
& \text { : بִ د وخت بانان } \\
& \text { د ترخ د ته }
\end{aligned}
$$

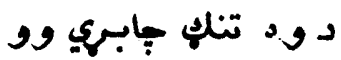

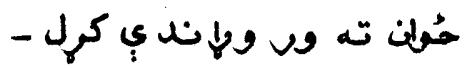

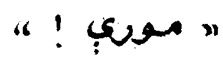

$$
\begin{aligned}
& \text { د نلمي غبِ. سكوت تغه كي } \\
& \text { او د بورى زور اهساس } \\
& \text { دفهل زلمي- خُران توكيدل آمان } \\
& \text { دي تورد شيهّ }
\end{aligned}
$$

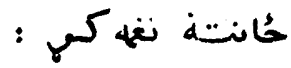

$$
\begin{aligned}
& \text { " نم دريم نه اخلمه " }
\end{aligned}
$$

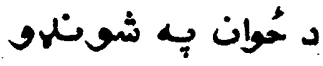

$$
\begin{aligned}
& \text { مسكوي مستون }
\end{aligned}
$$

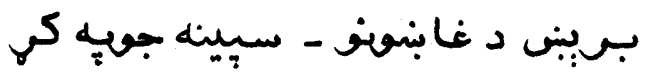

$$
\begin{aligned}
& +* \\
& \text { بمى مسله } \\
& \text { تاند زلميتوب ته } \\
& \text { دا با دا مي لبهه }
\end{aligned}
$$




$$
\begin{aligned}
& \text { ستركي دا بلي ديوي }
\end{aligned}
$$

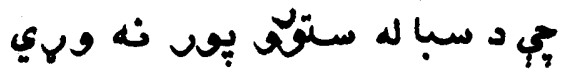

$$
\begin{aligned}
& \text { او مـابنا مي وينبته }
\end{aligned}
$$

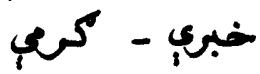

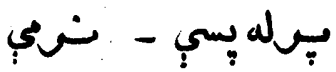

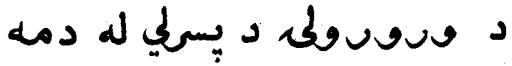

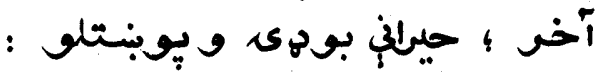

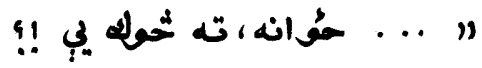

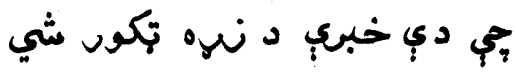

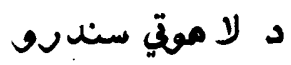

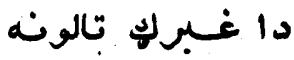

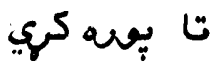

$$
\begin{aligned}
& \text { تهادوا تال غنبك كرئ } \\
& \text { د مكر اوجه - } \\
& \text { د لمه به خيرو اوجه }
\end{aligned}
$$

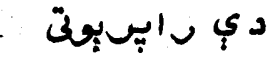

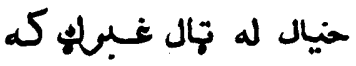




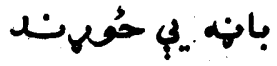

$$
\begin{aligned}
& \text { لكه تارونه } \\
& \text { د تصد صט:بنسم }
\end{aligned}
$$

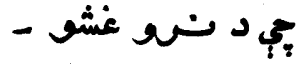

$$
\begin{aligned}
& \text { له كاب.ن نتم تاو كي؟ }
\end{aligned}
$$

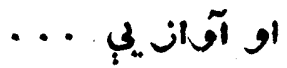

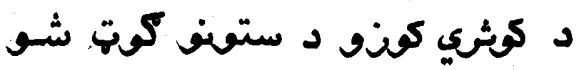

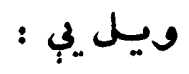

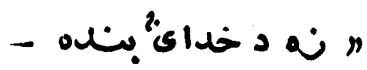

خداى" له دي تَولى بنسكلى

هغله له دي تولع نه بـى وكنبه

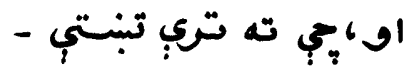

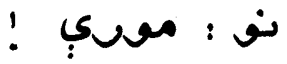

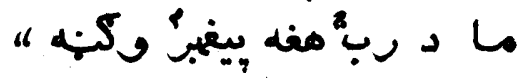

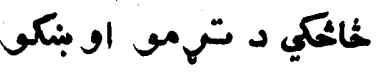

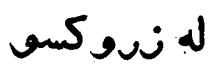

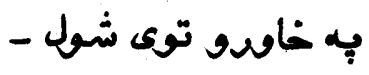

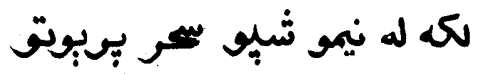

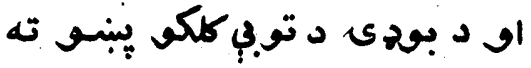

د سلو كالو د كناه له تنّي

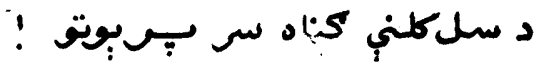




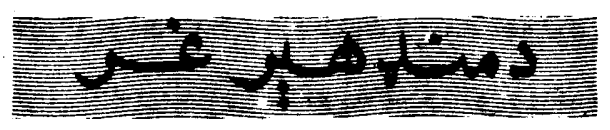

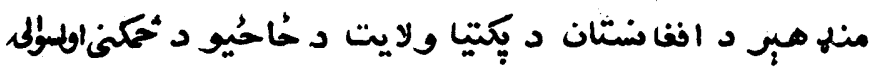

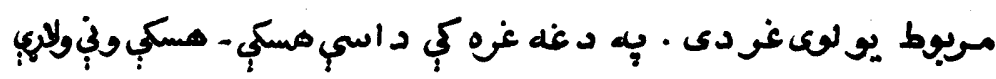

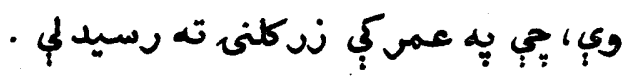

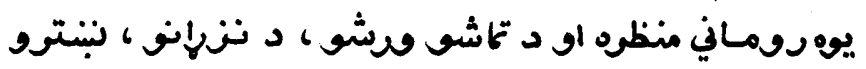

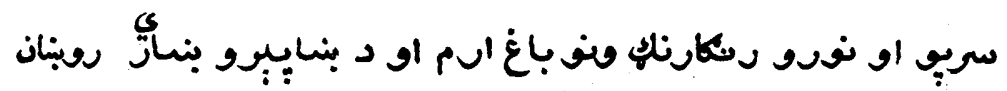

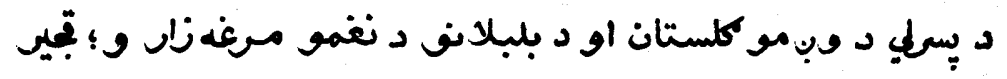
مسعان او بازونه د.منه مبر اوميد وتئي ثامونه دي .

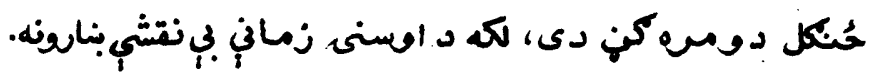

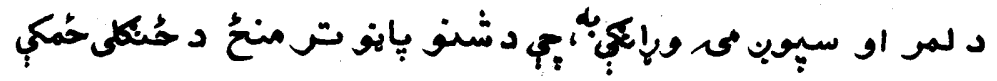

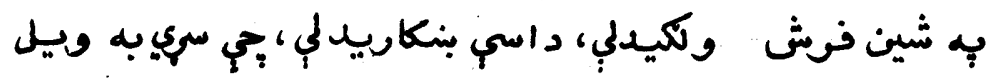

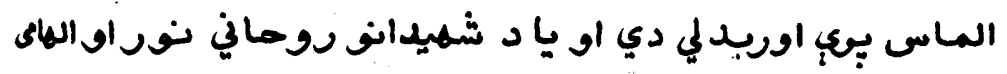
كرامت vى

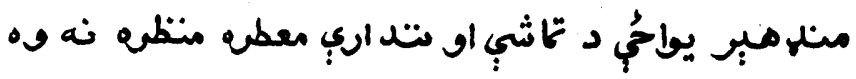




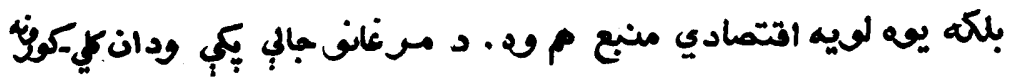

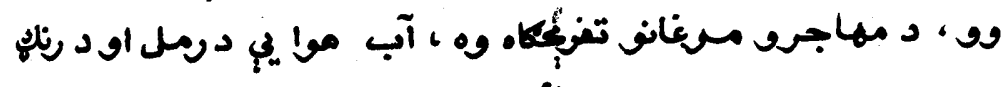

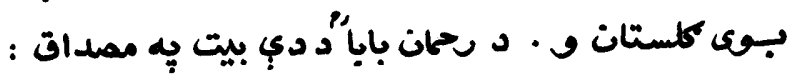

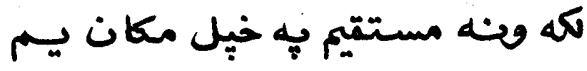
كه خنان الباندي إشي- كه بـهار

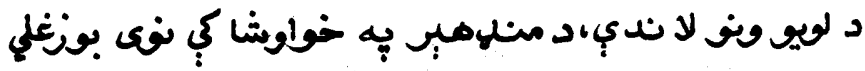

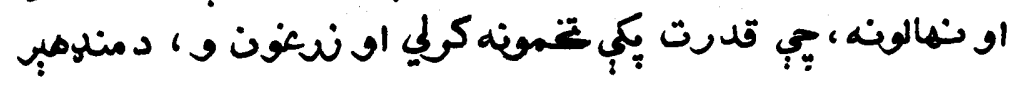

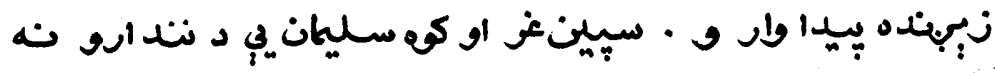

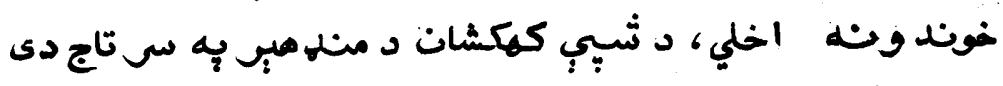

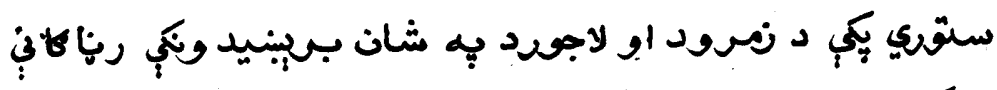

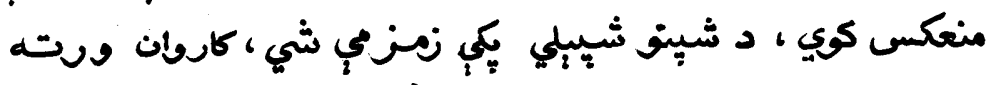

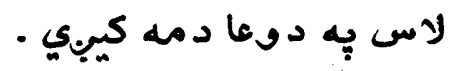

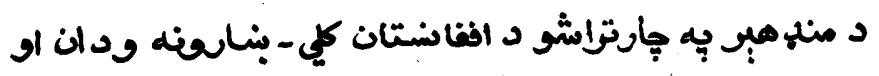

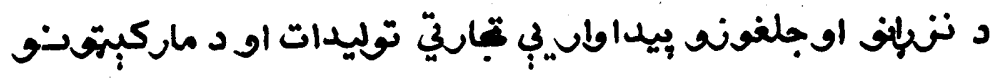

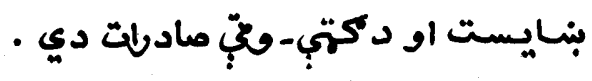

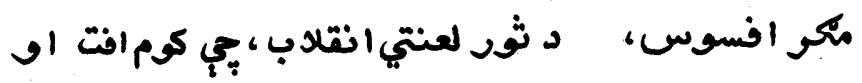

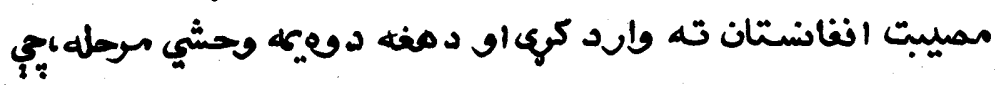

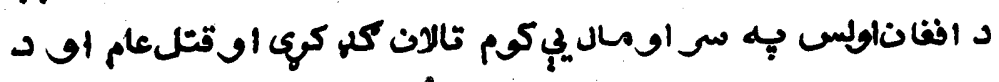

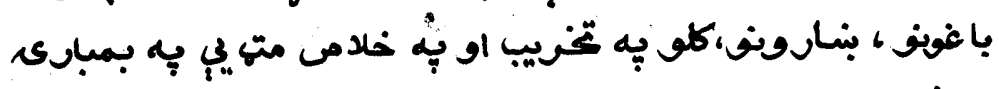

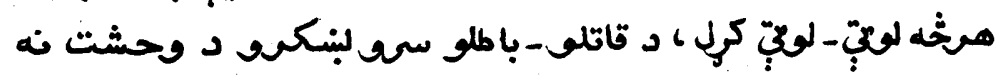

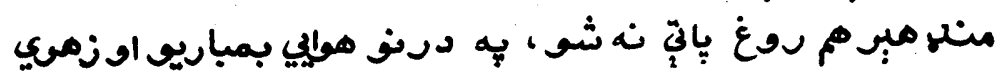




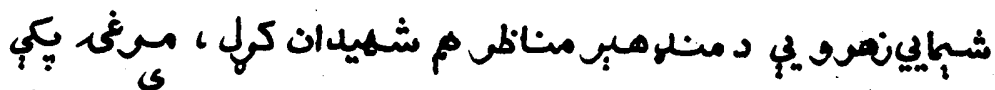

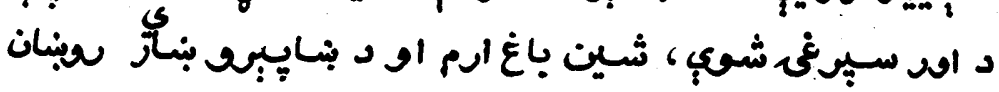

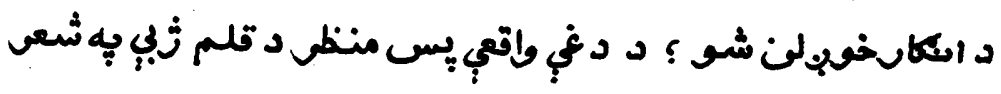
:

\section{! Odida}

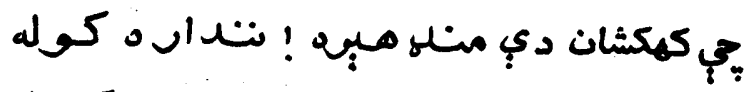

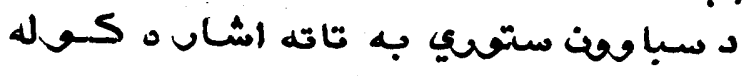

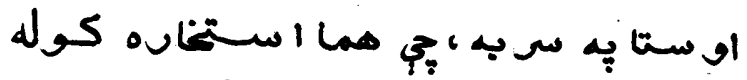

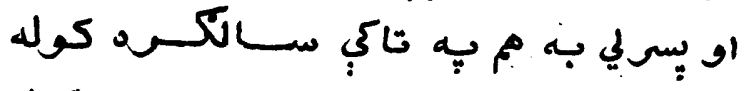

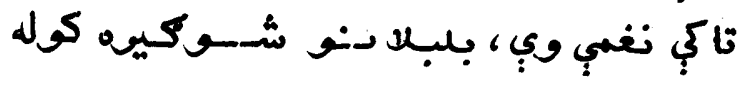

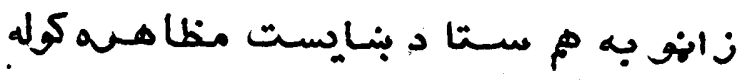

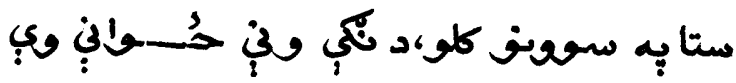

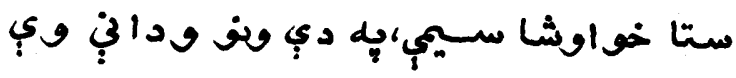

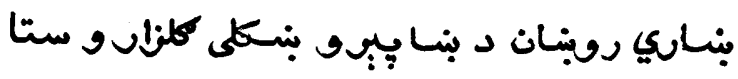
يه تلك او بوى به معطر ممثبشى بهان و ستا

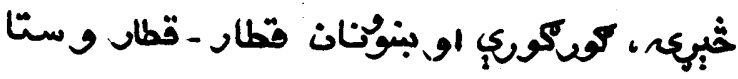

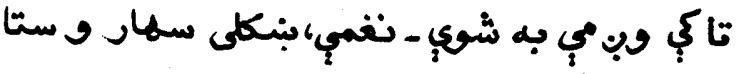


لئي-ختك

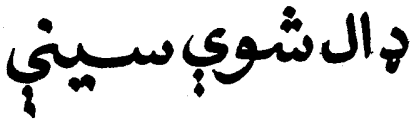

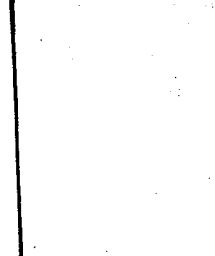

$$
\begin{aligned}
& \text { خوشال بابا وميلي وى : }
\end{aligned}
$$

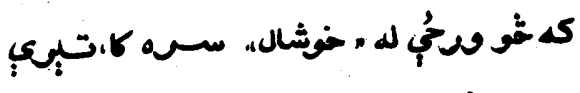

$$
\begin{aligned}
& \text { دا د دنه ختهك به والو شـاعـران شي }
\end{aligned}
$$

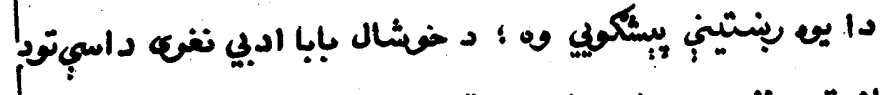

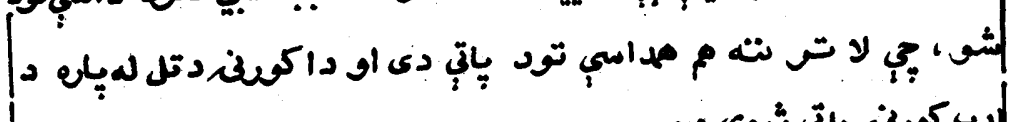

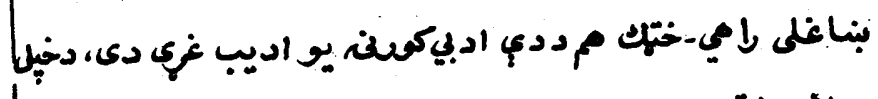

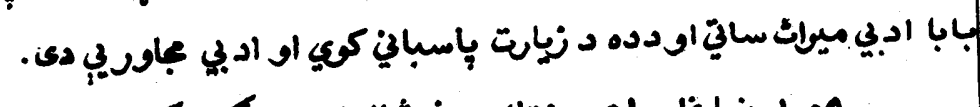

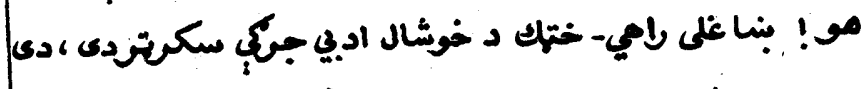

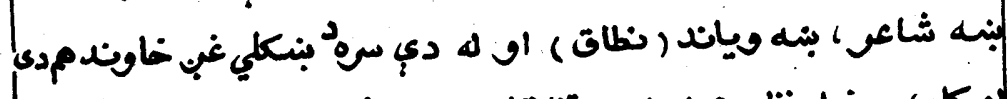

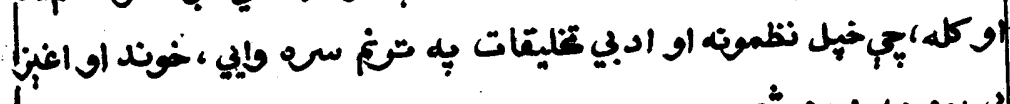
•

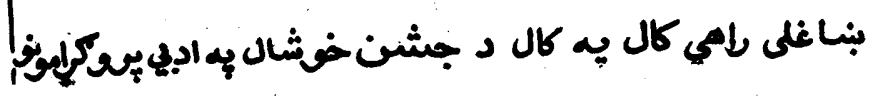


سـتا د زخمونف عزلمـات به تري تكام اخليم

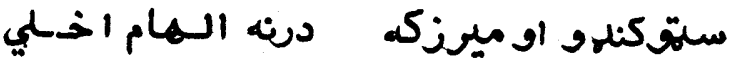

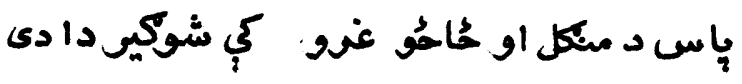

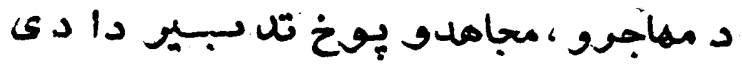

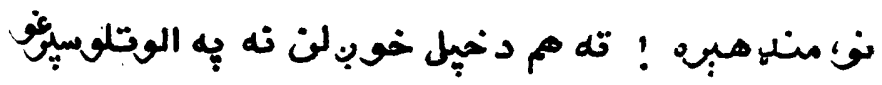
د ثخى يه وحشي انقلا ب باندي لعنت لايه ، ئ ستا لمبهددهريانى

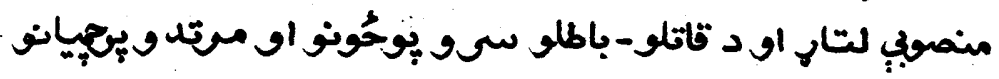

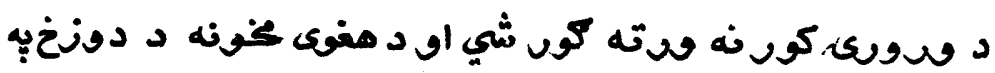

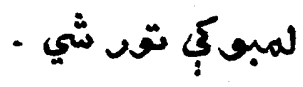

\section{:}

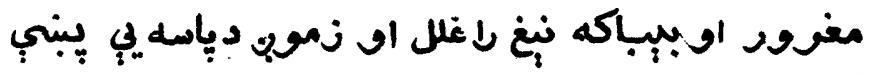

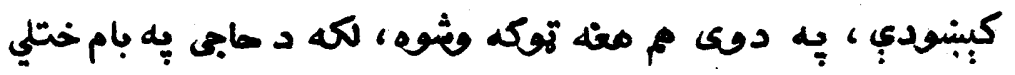

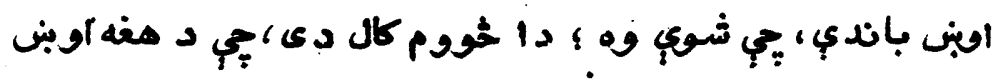

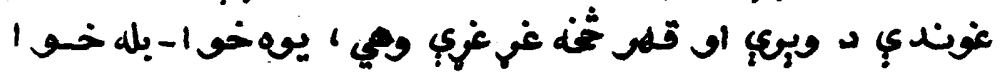

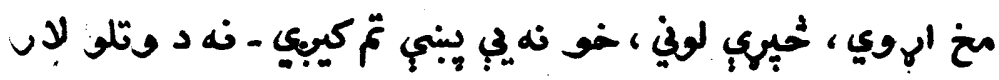

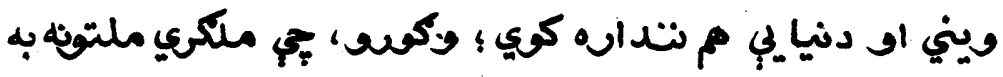

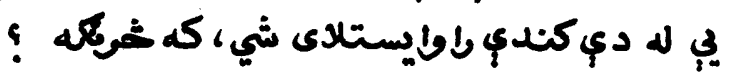




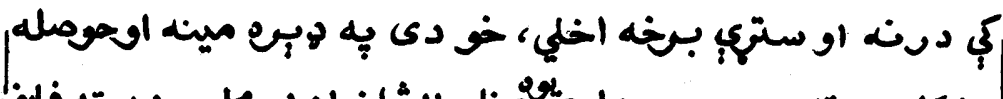

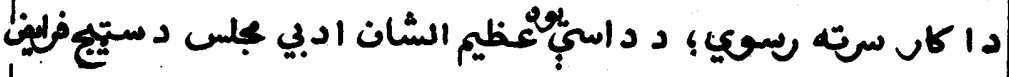

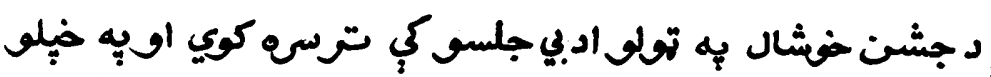
خوبنو خبرو جلس خوب: اوكرم سائي .

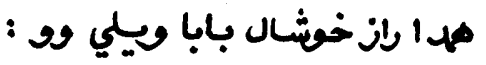

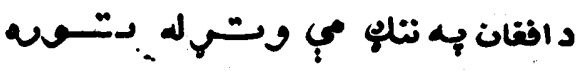

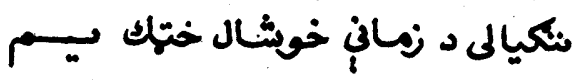

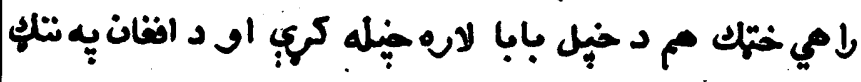

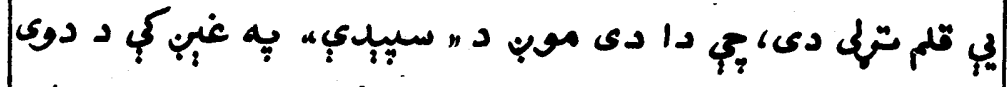

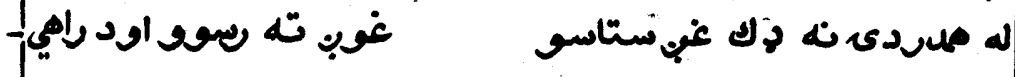

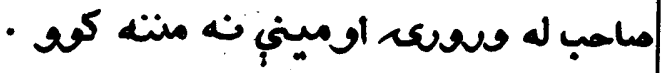

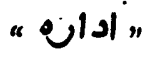

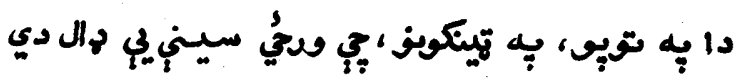

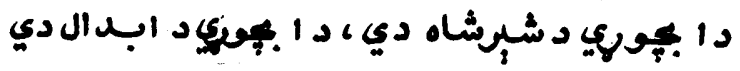

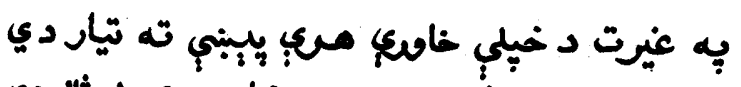

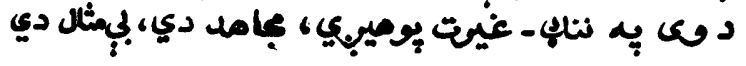

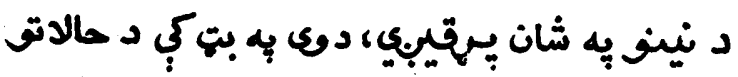

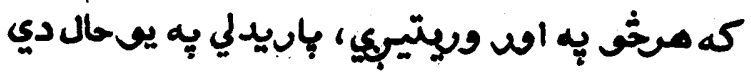




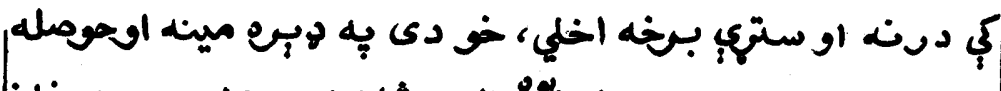

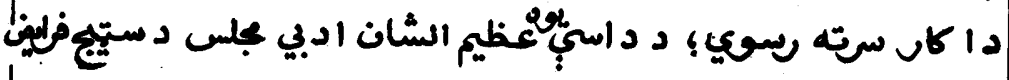

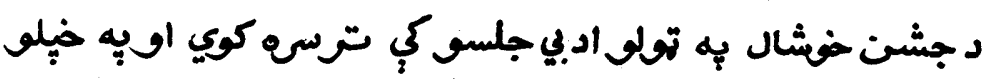
خوب:وخبرو بلس خوب اوكرم ساتيّ .

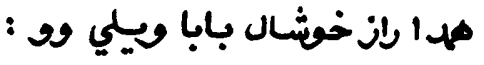

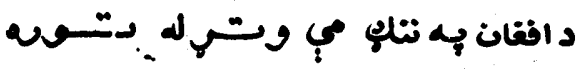

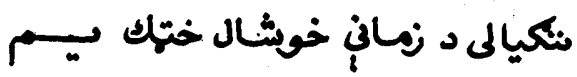

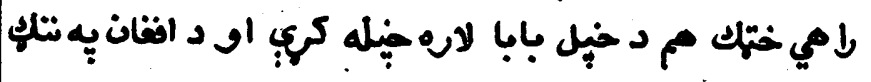

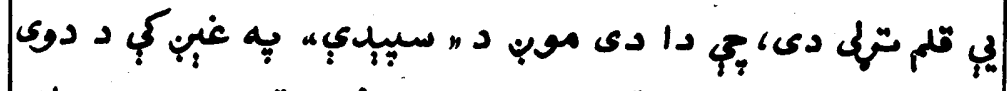

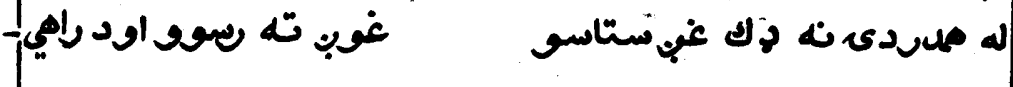

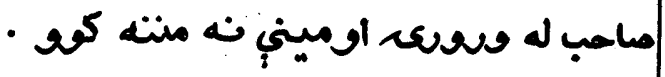
"ن أن إن"

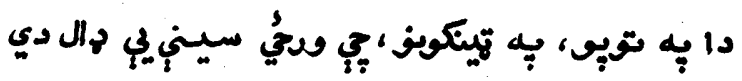

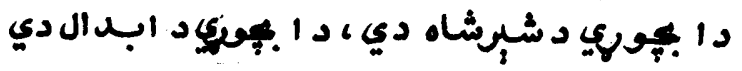

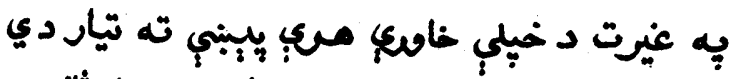

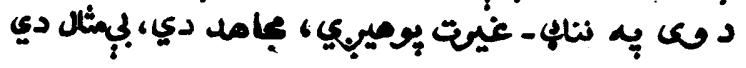

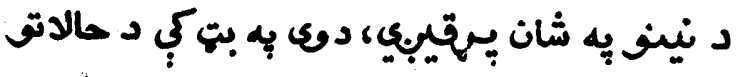

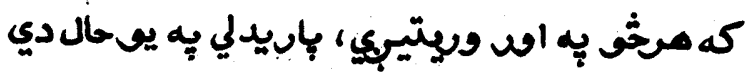




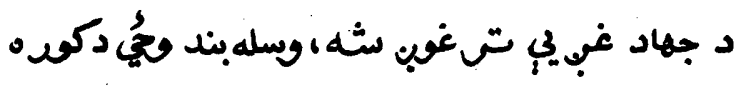

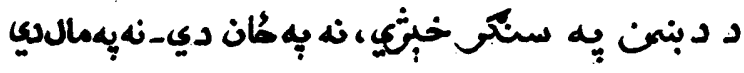

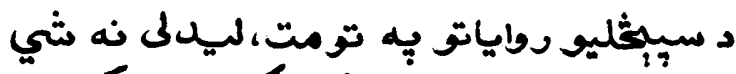

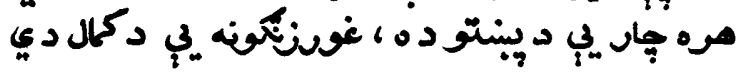

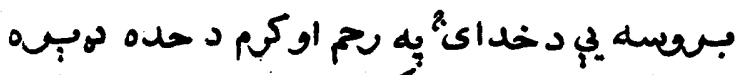

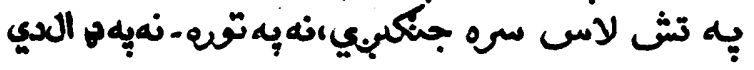

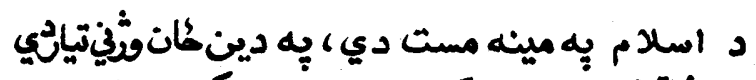

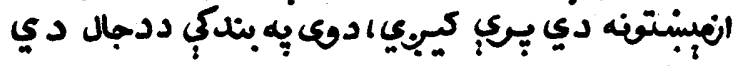

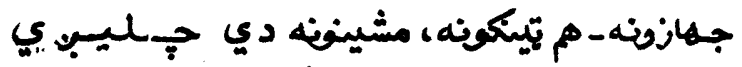

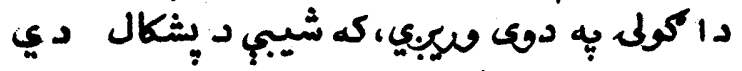

د انفان مطن كي خدايه'مرك،د هري خوآمت كيوي

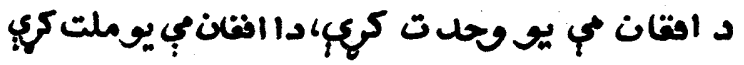

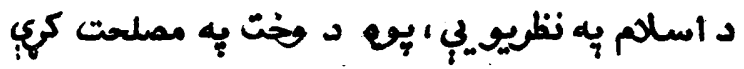

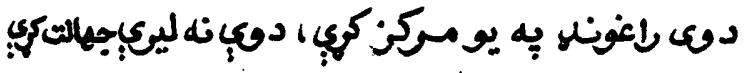

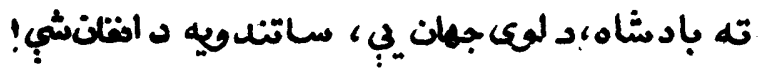

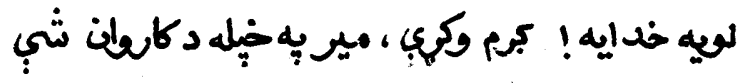




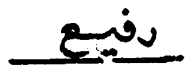

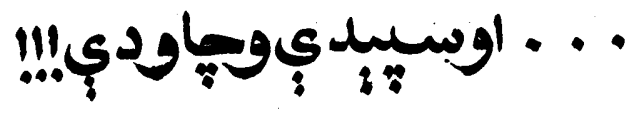

د نويح فضا له دورو دكه وع او له كيحونو .

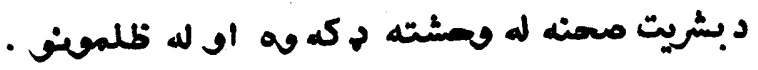

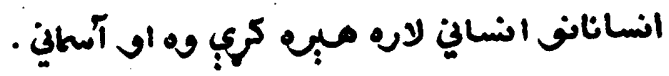

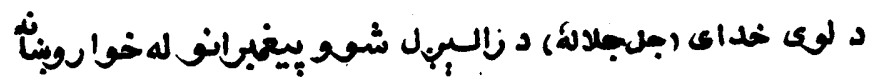

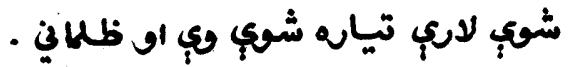

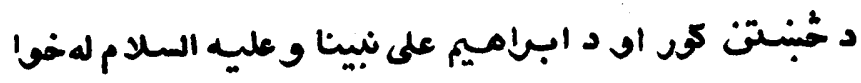

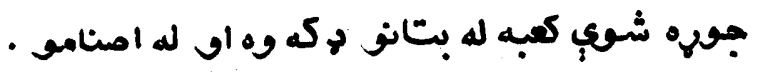

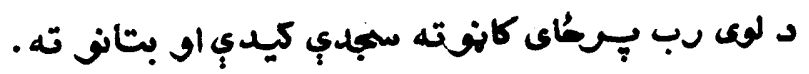

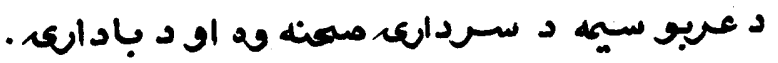

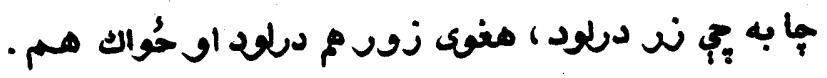

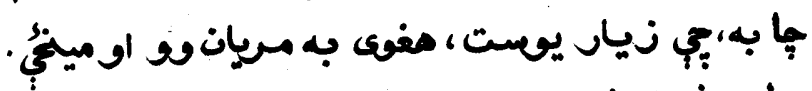

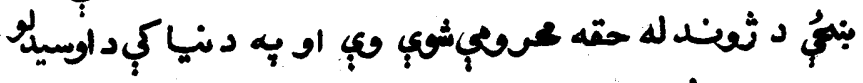

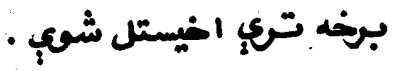




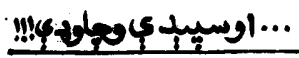

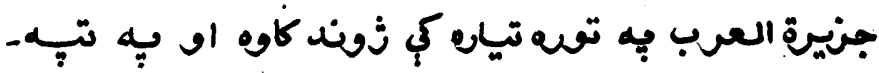

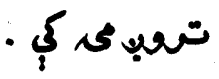

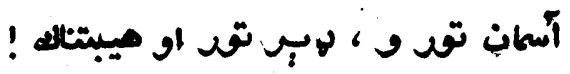

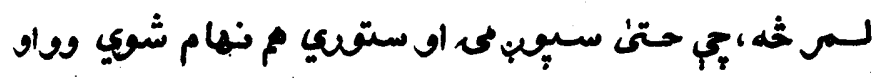
د دئالمسى ورك شـوع .

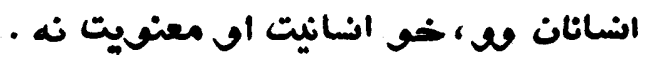

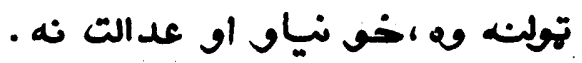

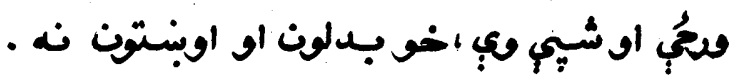

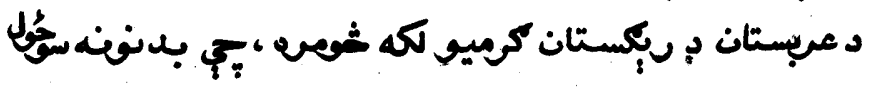

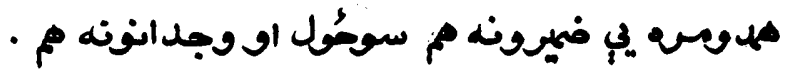

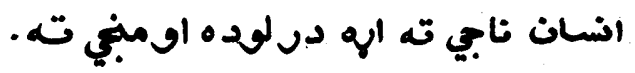

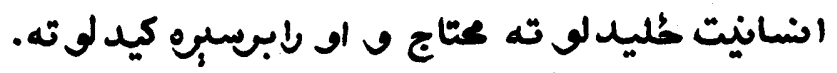

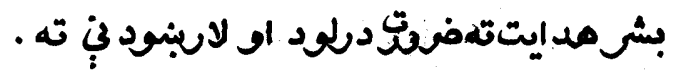

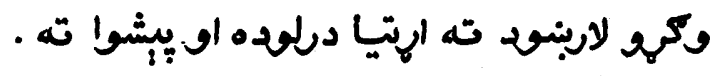

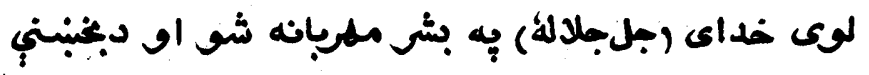

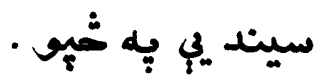

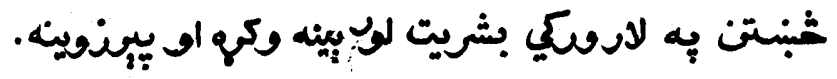

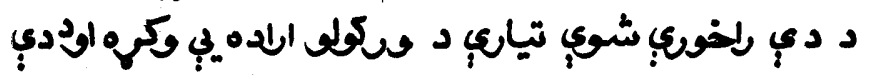

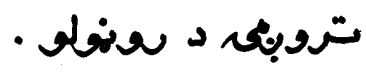

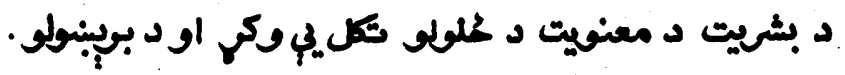




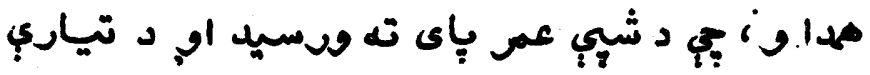
دصس الخجم ته - دمان

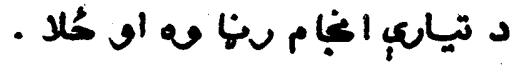

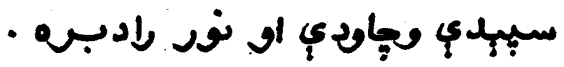

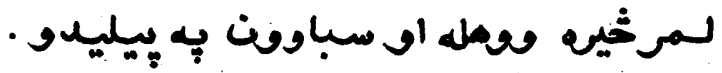

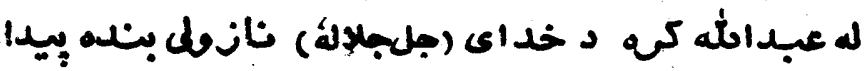

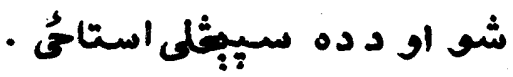

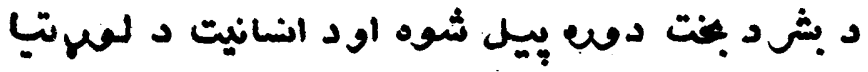

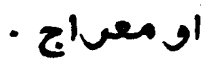

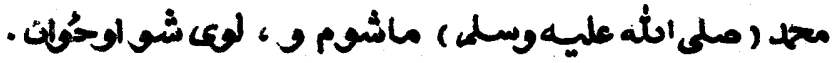

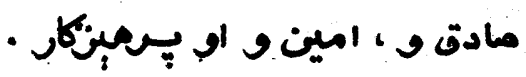

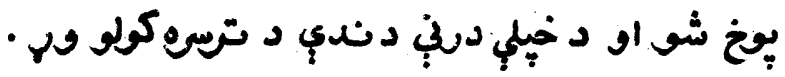

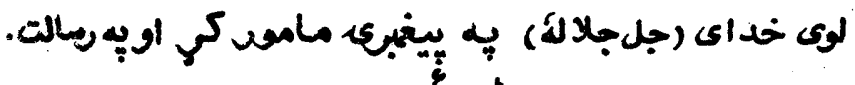

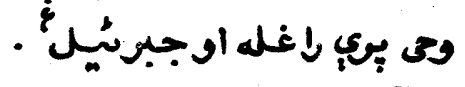

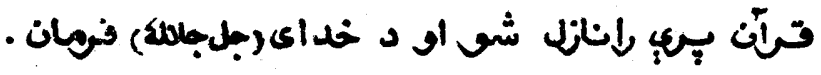

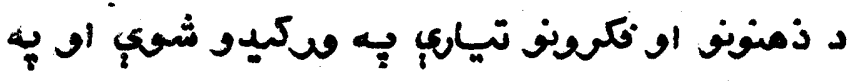

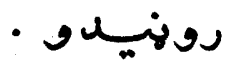

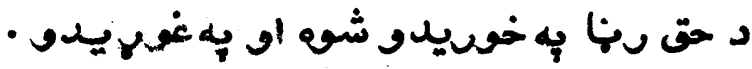

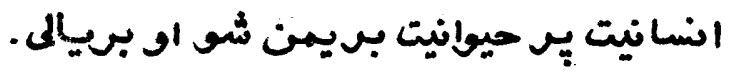

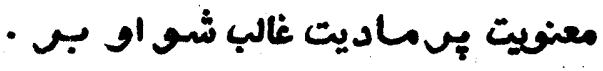

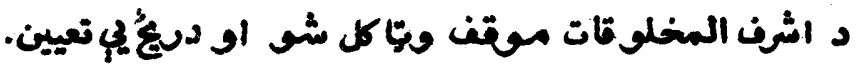


د بتانف او كانو لمانثيه بنده شوق او د لوى خداى(جلجلائ)

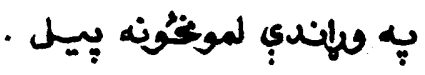

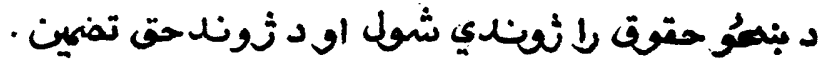

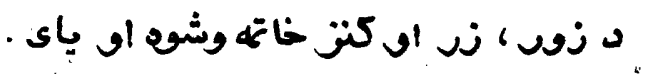

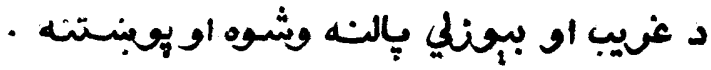

د مساوات او علالت دين لإ غَ اود سولي او سلام

$$
\text { - }
$$

د اسـلام د حت دين لمن لسمب خوره شمه او بيأخه .

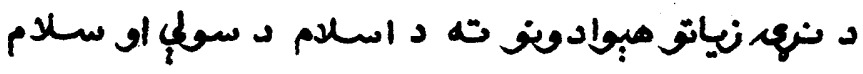

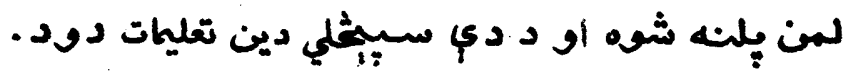

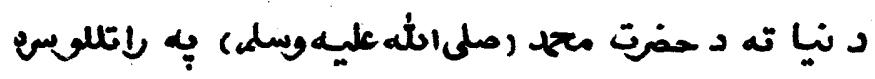

$$
\text { تياص د تل له بإص وركه شهوه . }
$$

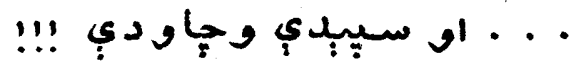

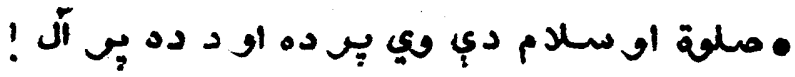

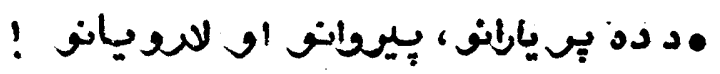

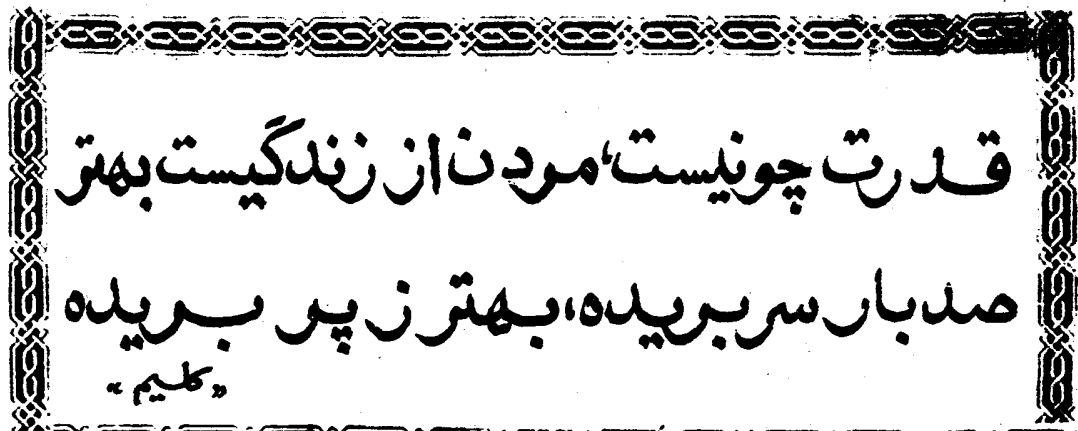
(0. 
دوستان ديد مبشغواب امشب مىكثتم شهيد خويش إ بلهرخدا درعيد قريان مىكنم .

شينِكل

$$
\text { لوى زنه }
$$

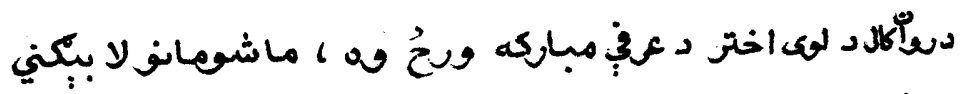

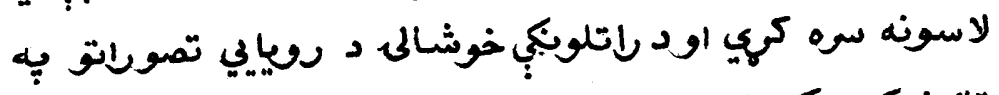

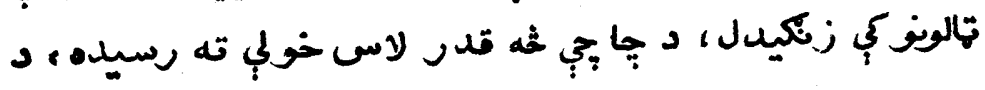

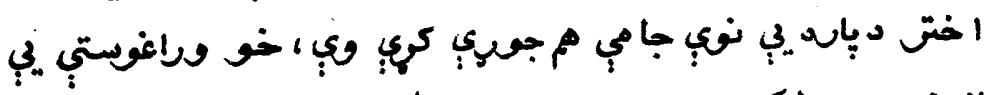

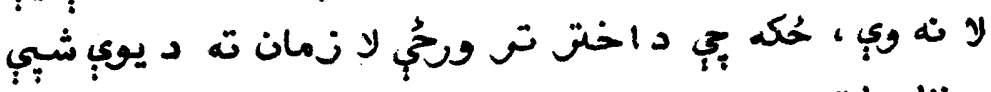

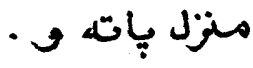

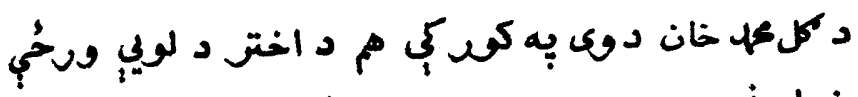

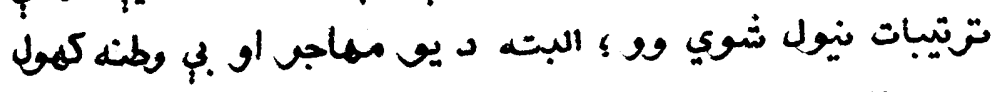

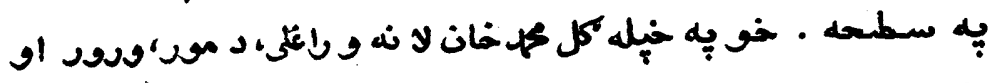

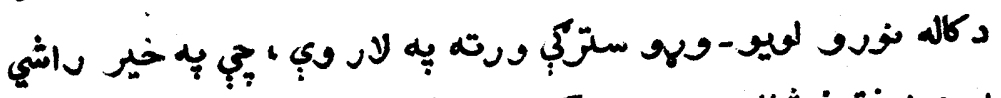

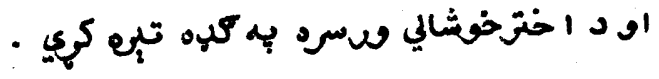

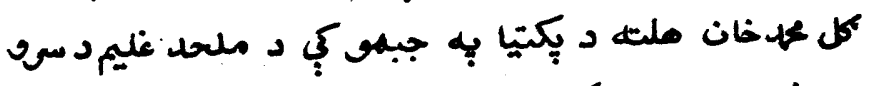

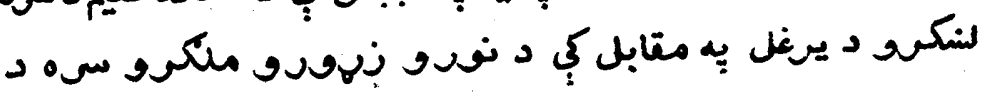


وينس

$r$.

سيمدي

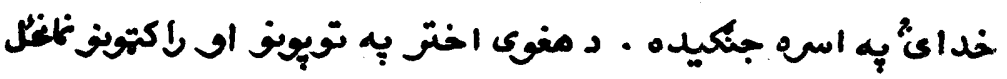

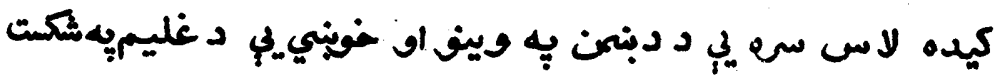

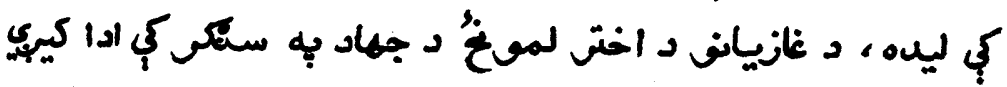

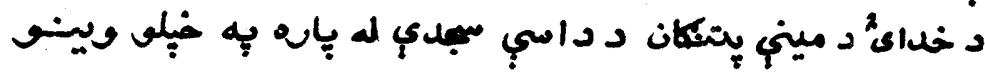

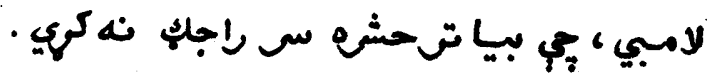

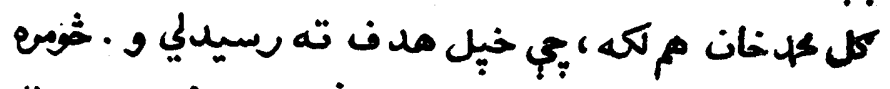

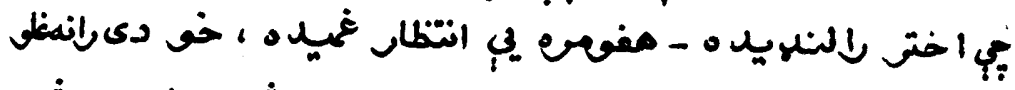

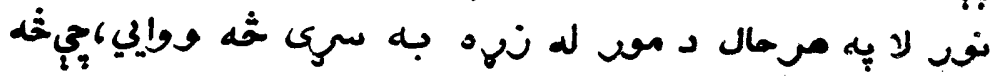

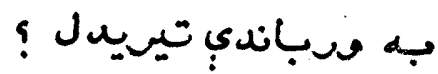

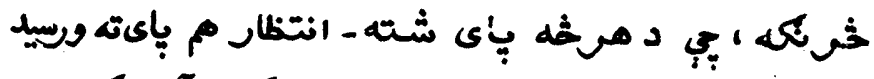

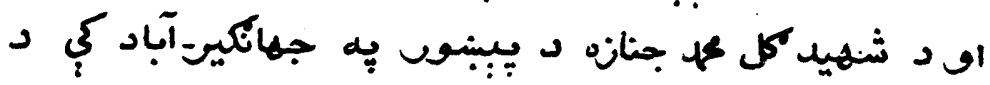

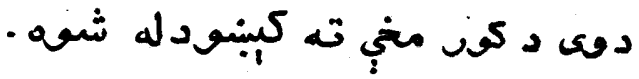

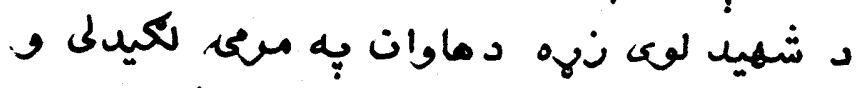

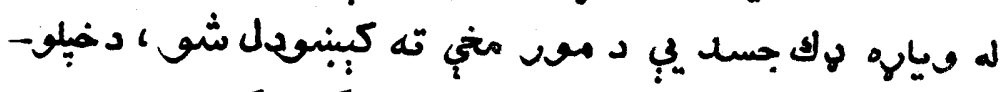

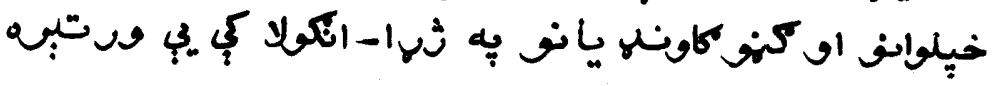

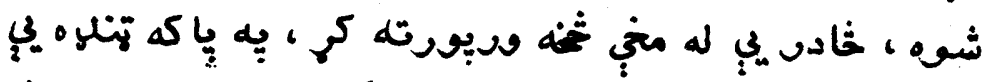

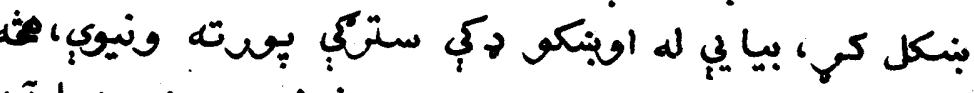

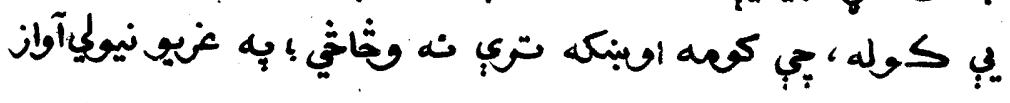
يجي وقيل

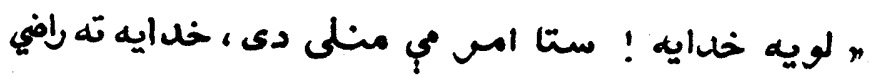

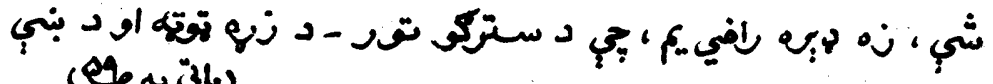
(يكابّ بيه 
توبيالقهماهئ

دتّبانخاختق

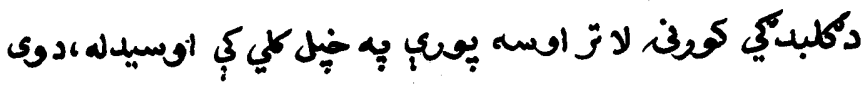

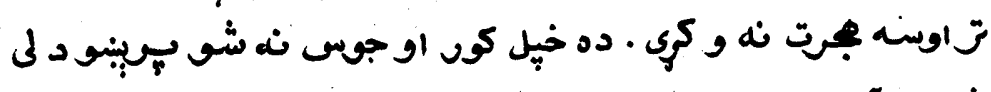

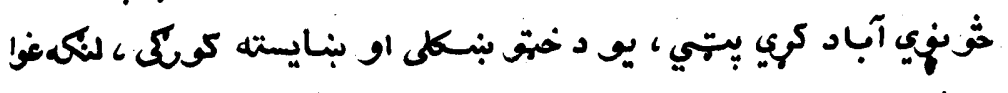

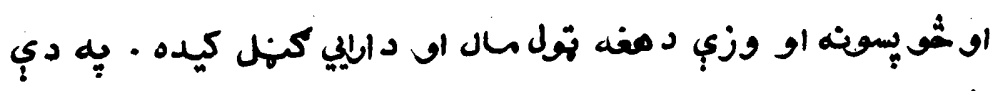

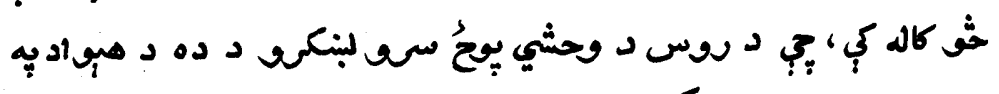

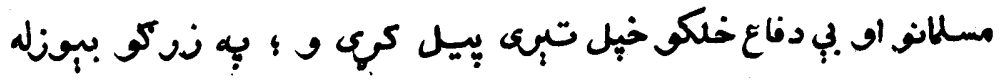

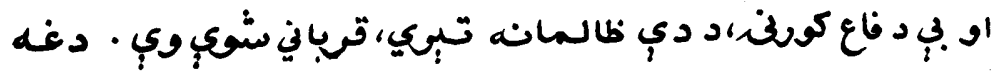

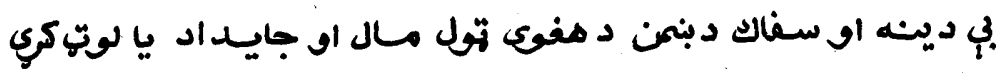

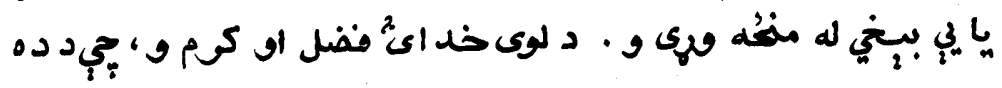

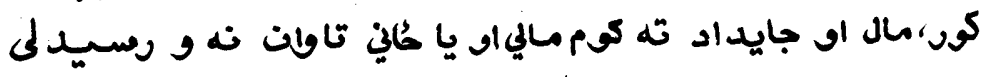

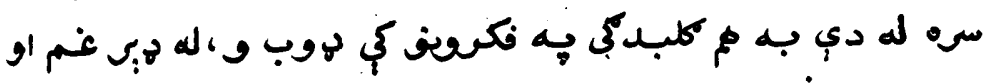

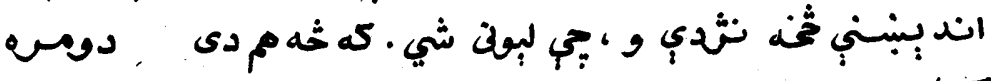

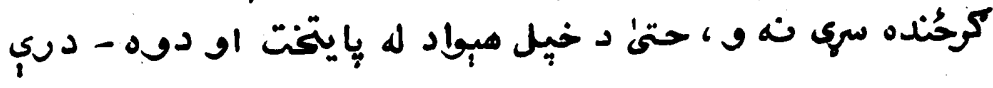




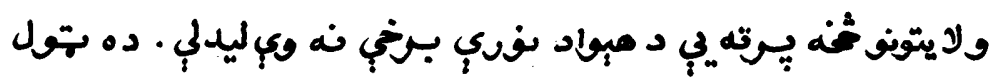

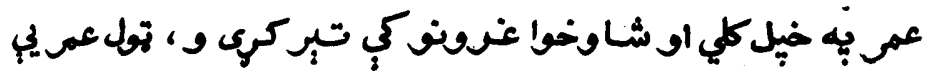

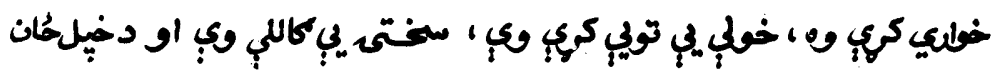

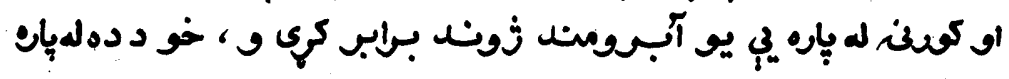

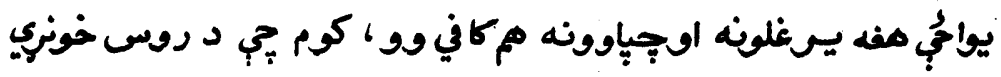

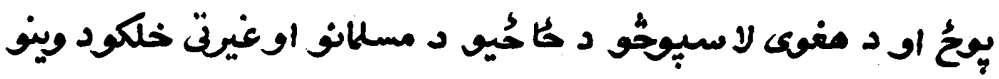

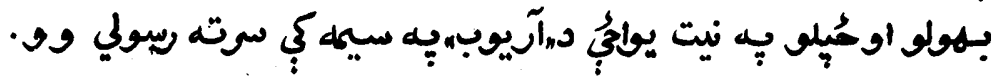

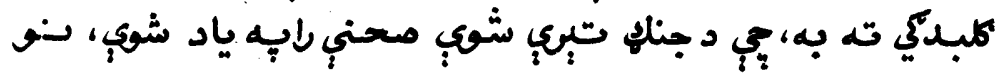

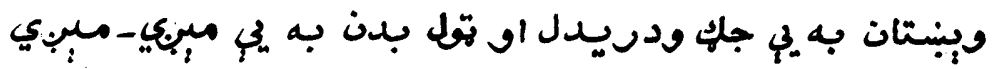

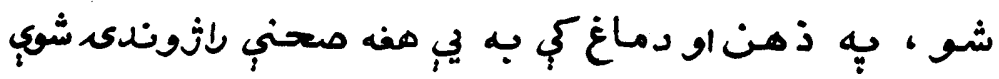

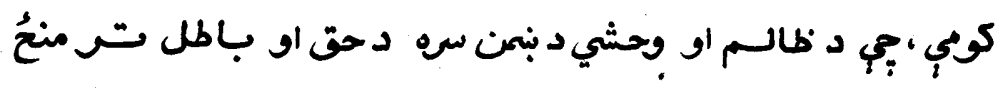

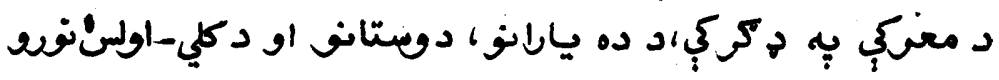

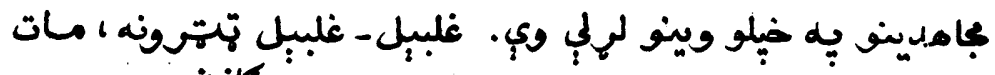

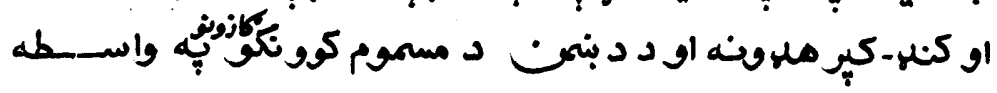

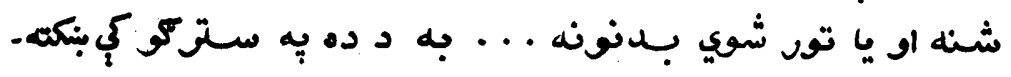

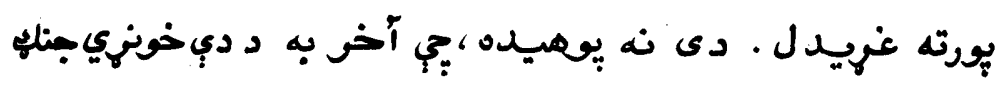

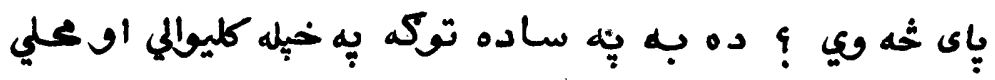

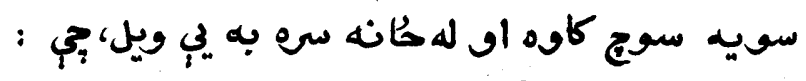

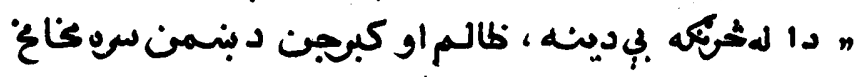

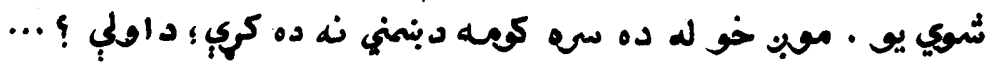

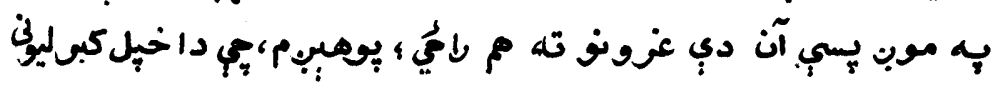




\section{دقيانزاختر}

$r r$

كسيوب

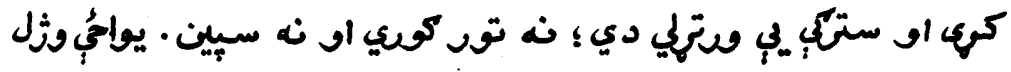

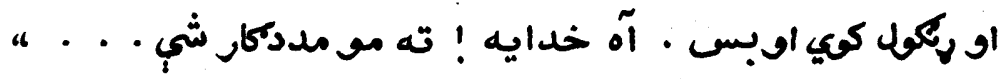

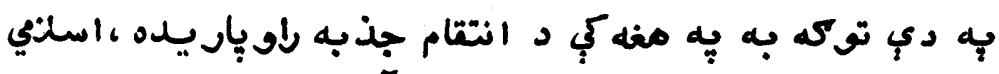

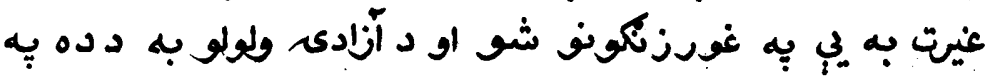

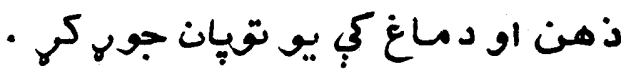

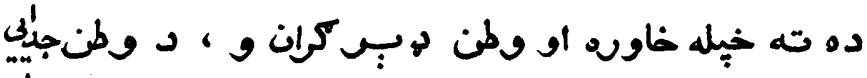

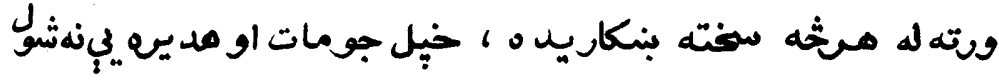

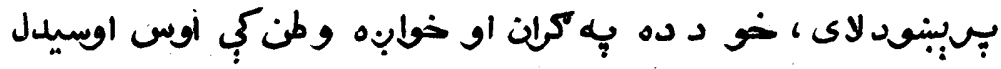

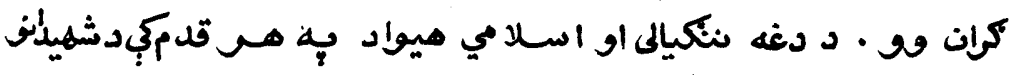

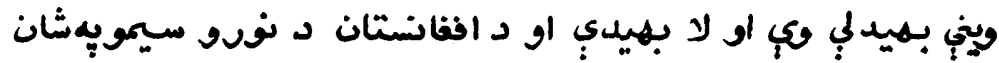

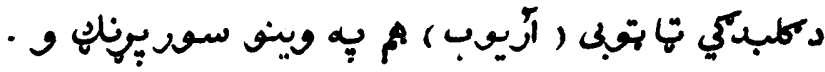

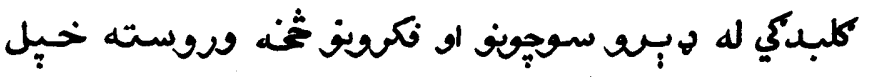

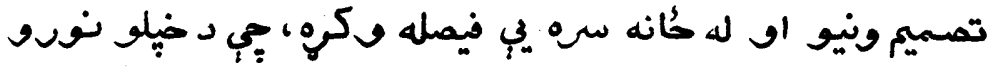

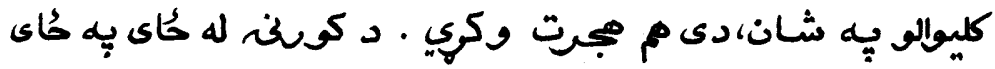

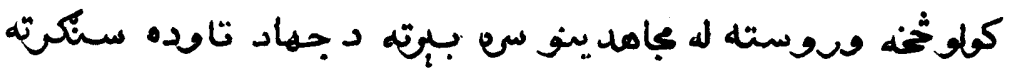

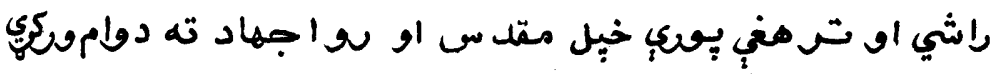

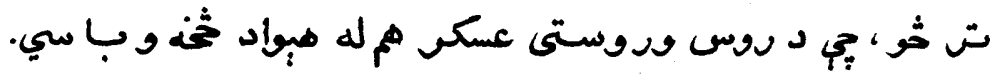

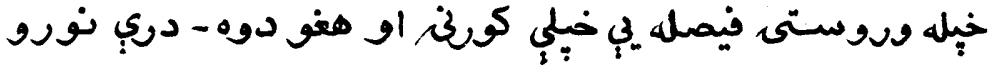

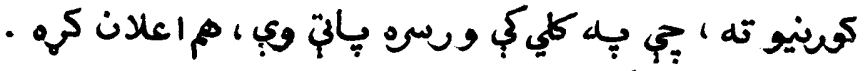

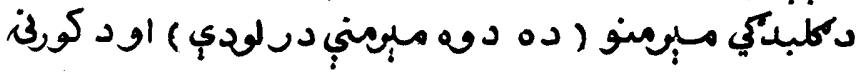

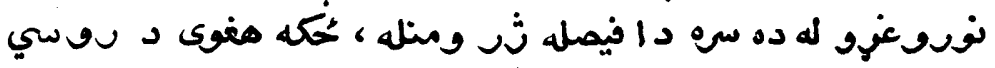




\section{دقربانراختر}

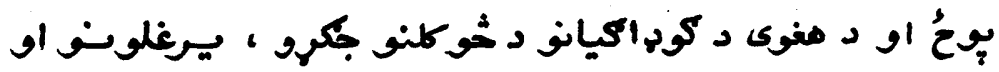

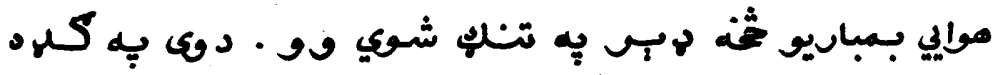

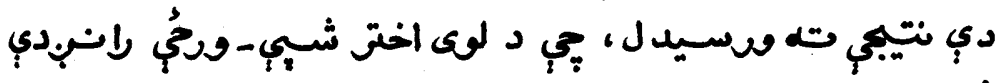

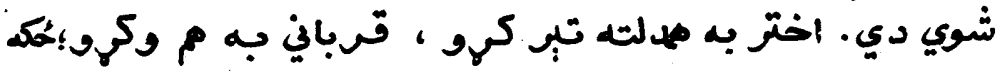

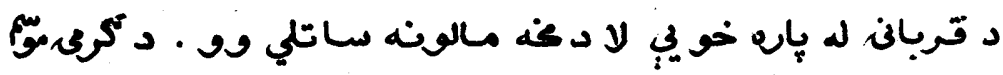

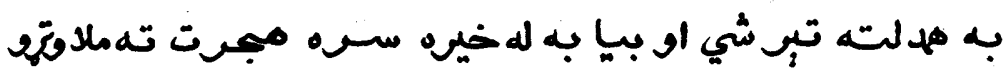

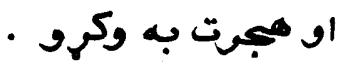

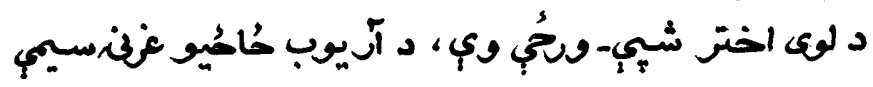

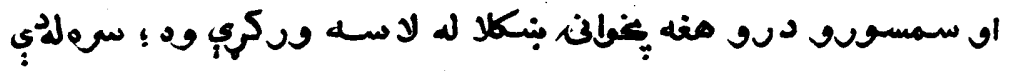

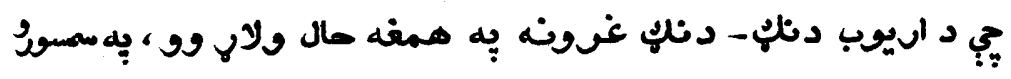

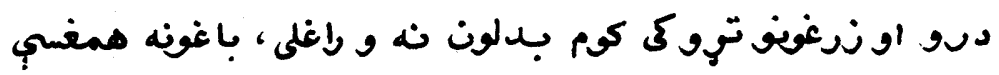

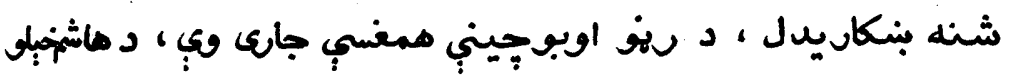

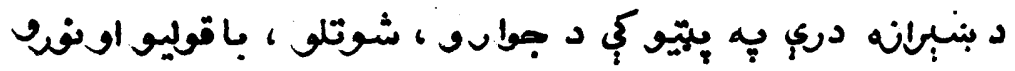

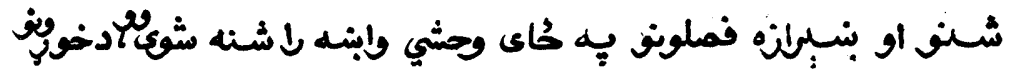

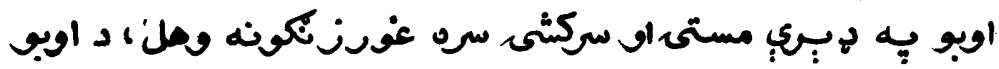

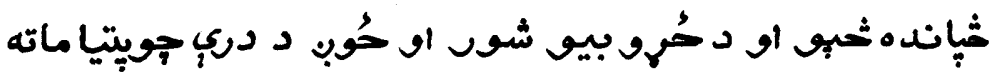

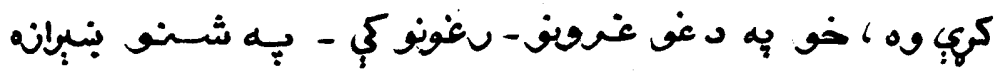

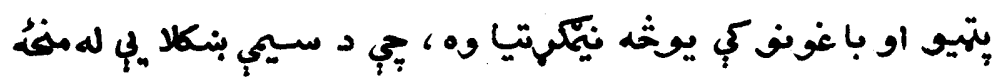

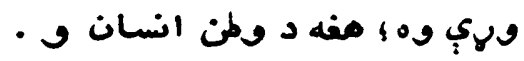

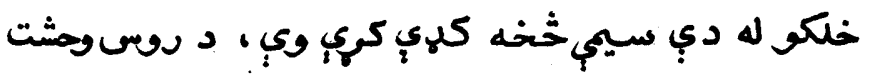

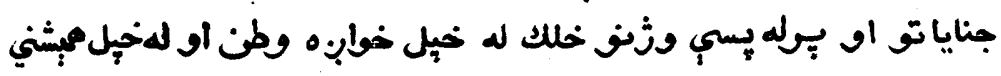




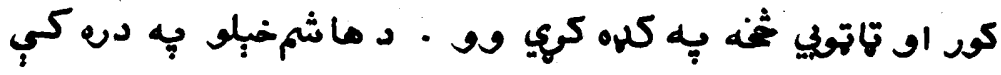

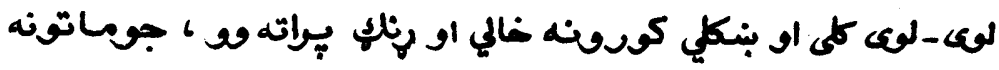

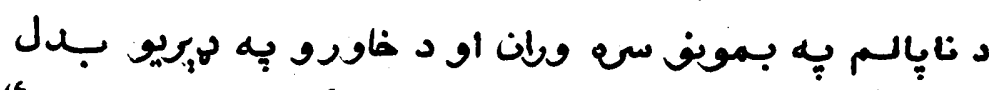

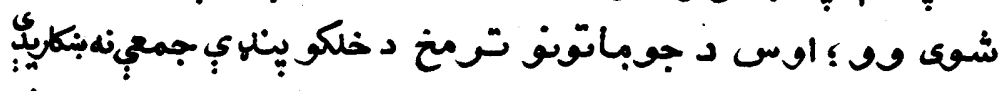

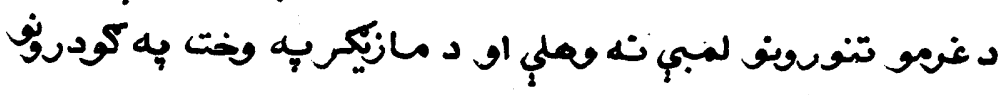

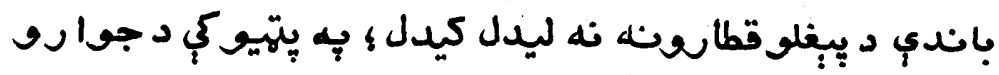

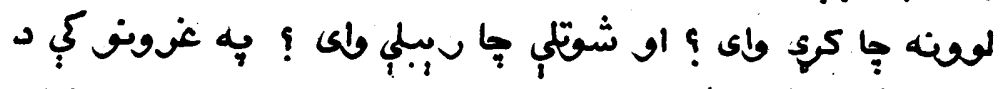

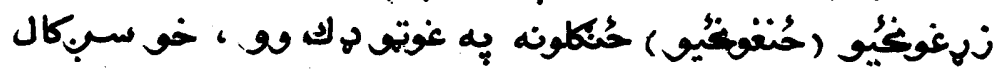

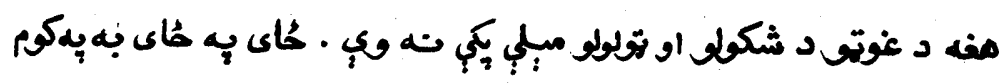

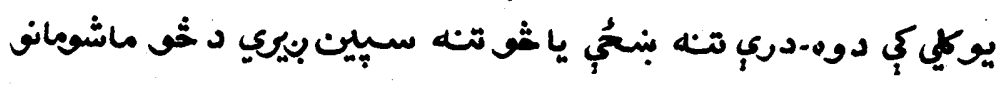

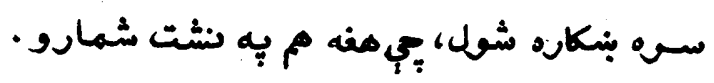

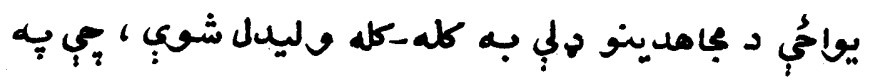

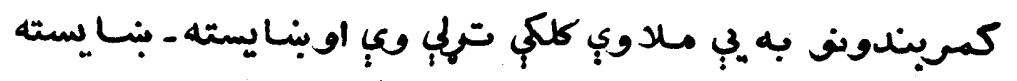

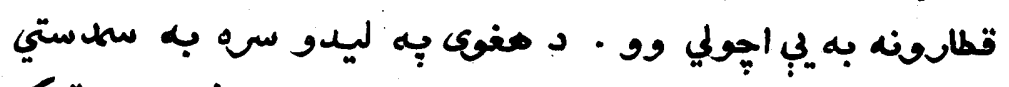

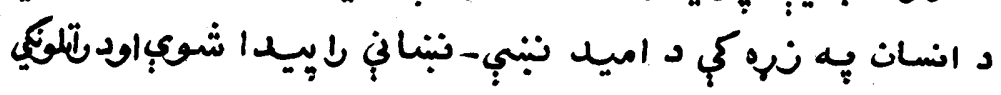

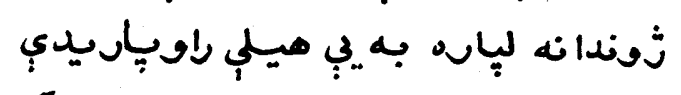

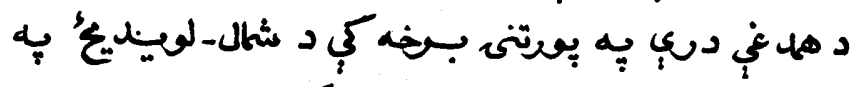

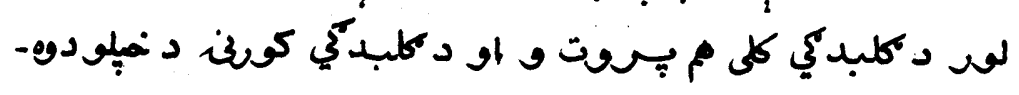

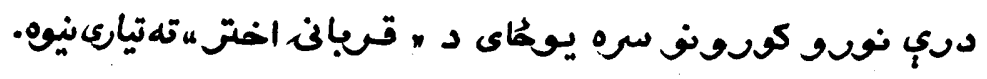

* * * *

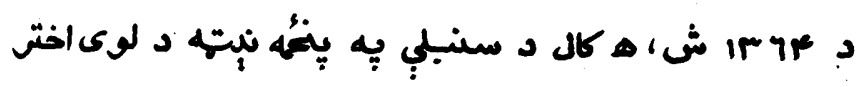




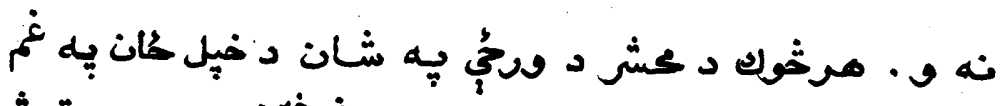

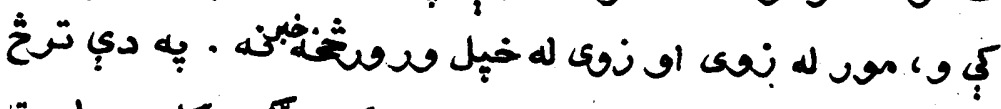

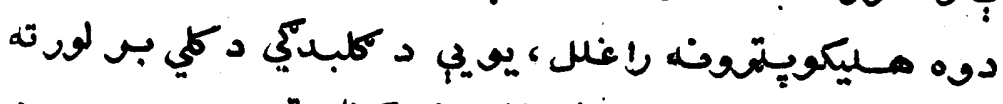

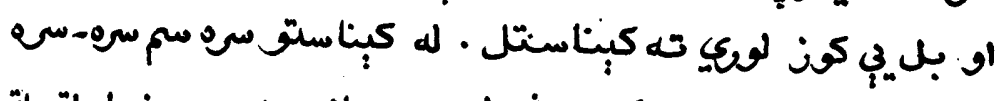

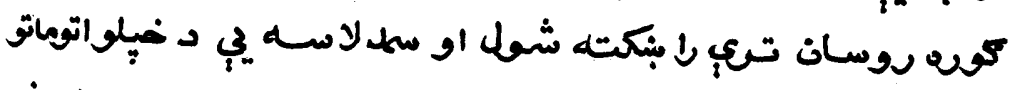

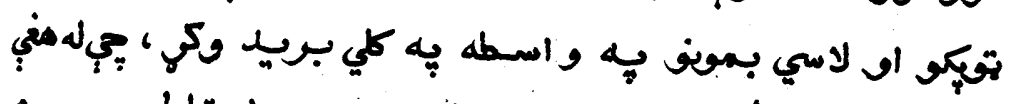

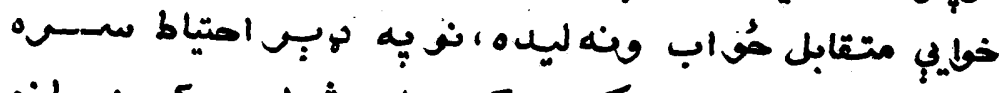

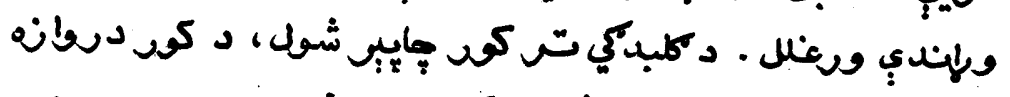

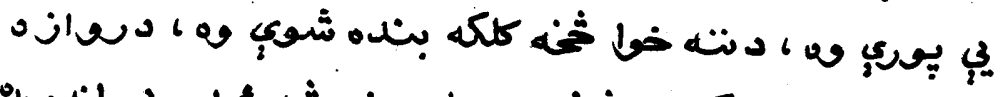

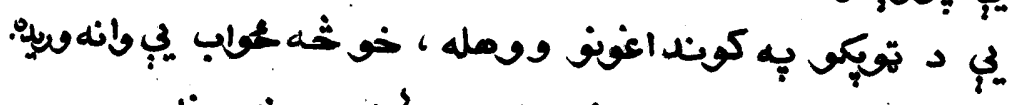

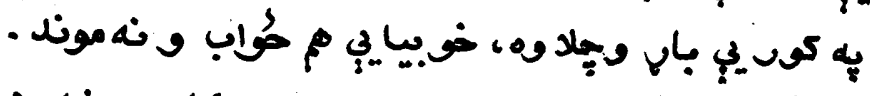

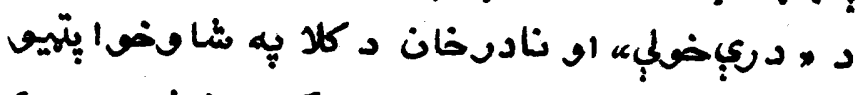

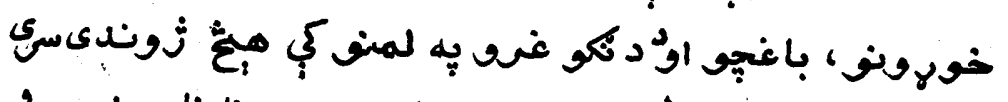

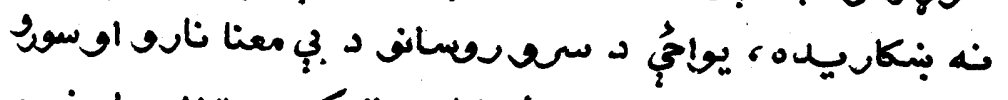

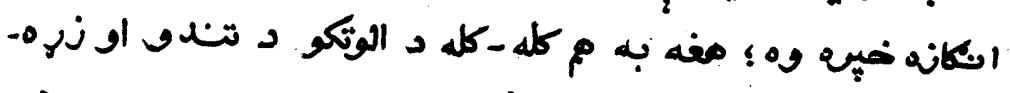

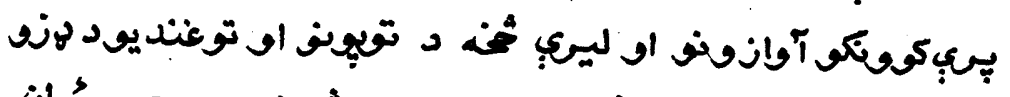

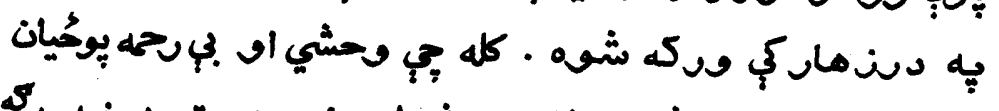

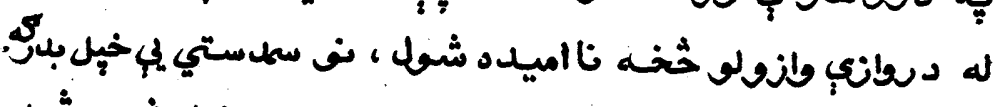

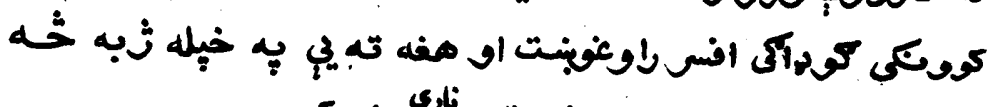

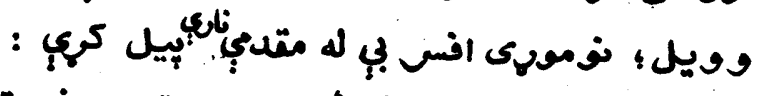

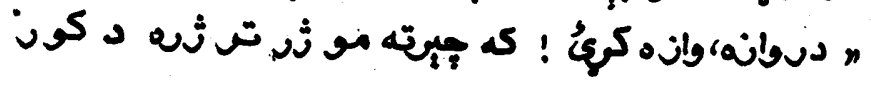


دقرباناختى

ry

سبدبsى

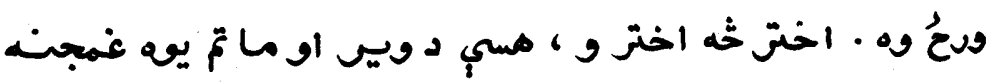

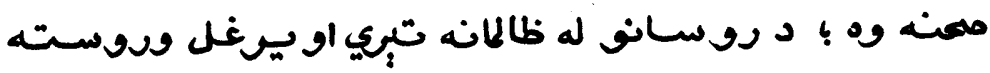

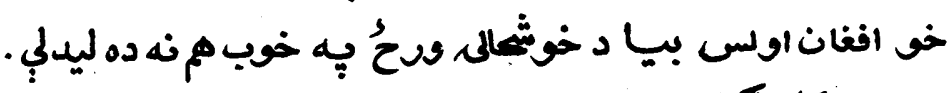

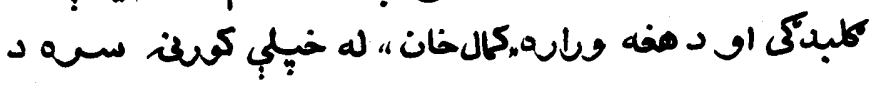

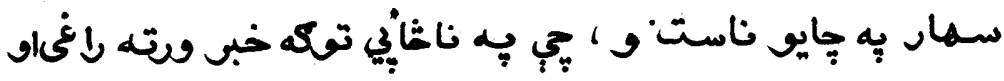

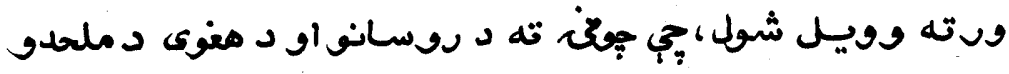

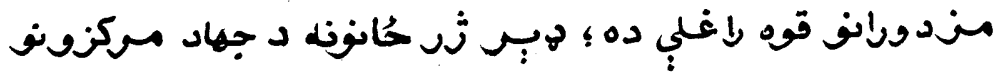

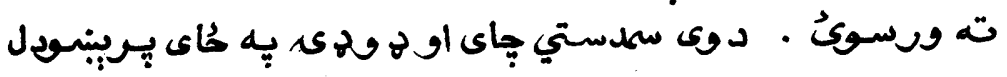

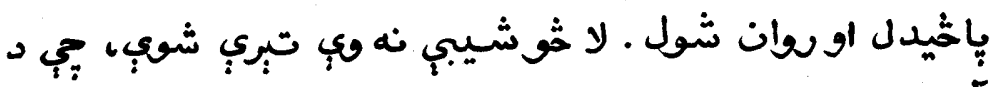

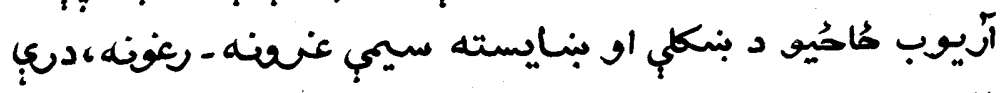

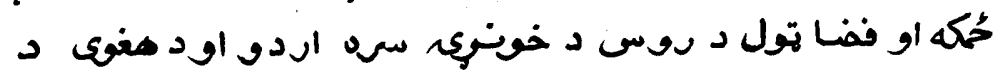

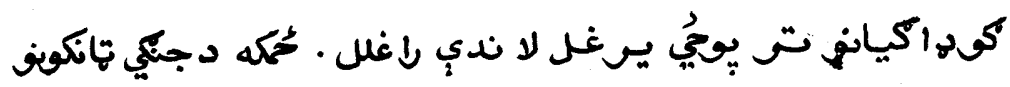

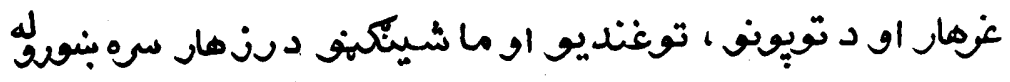

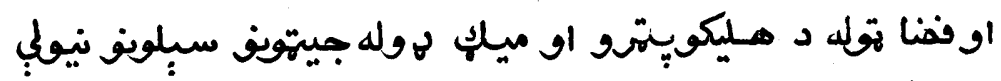

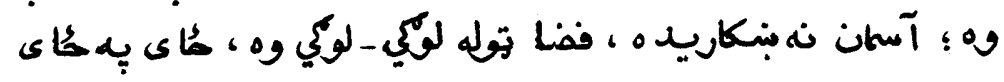

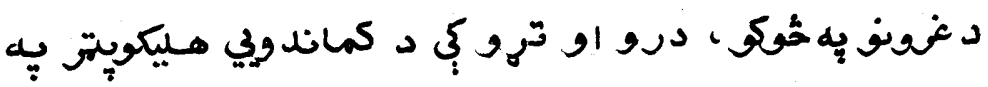

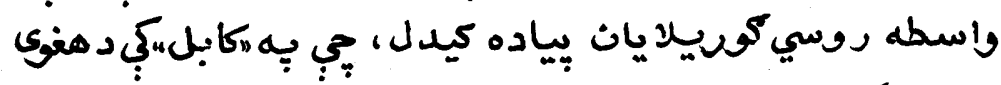

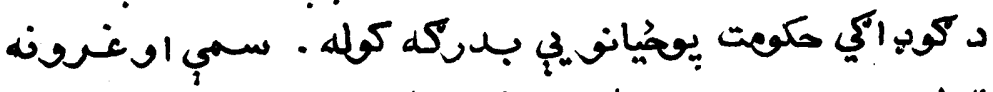

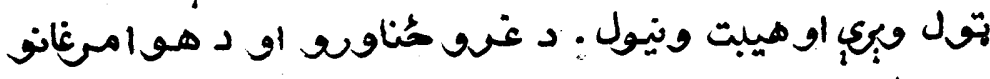

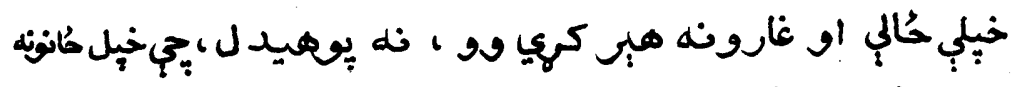

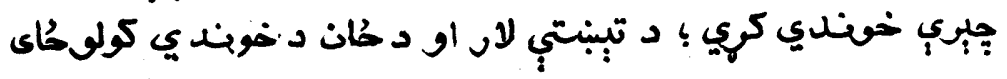




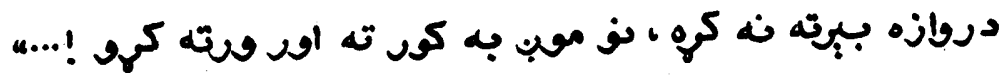

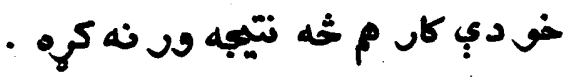

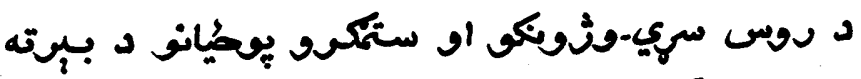

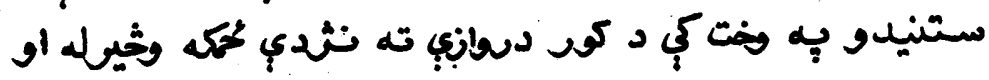

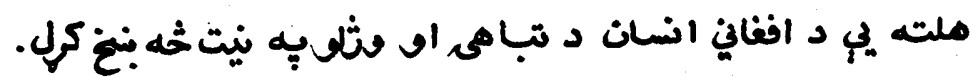

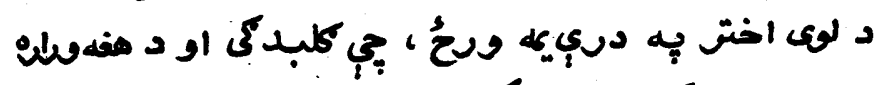

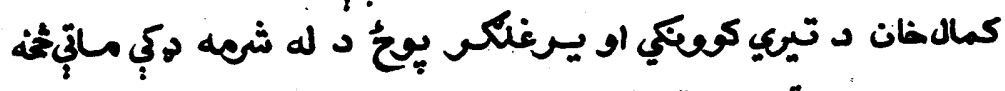

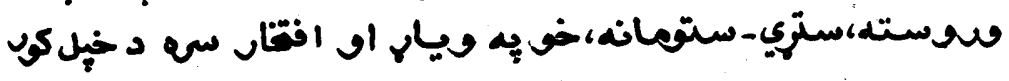

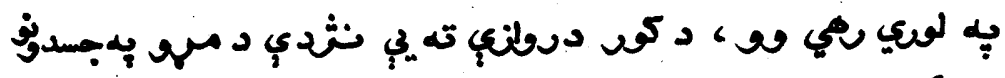

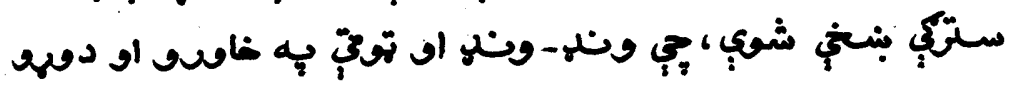

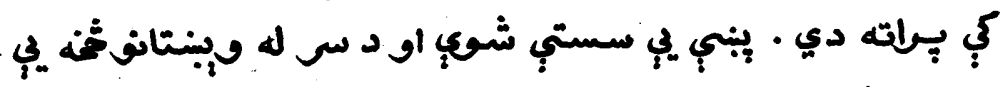

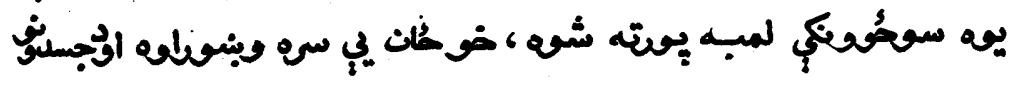

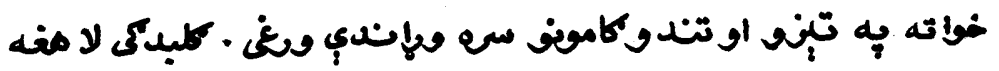

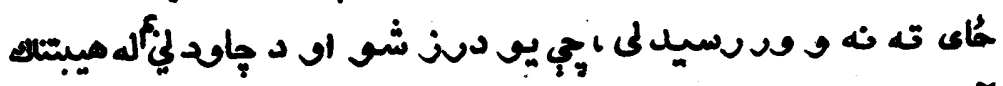

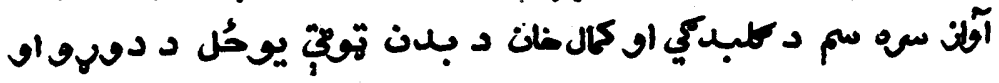

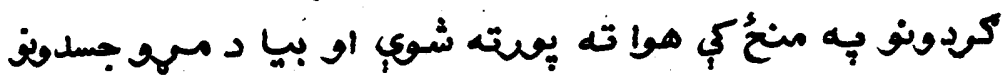

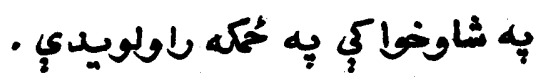

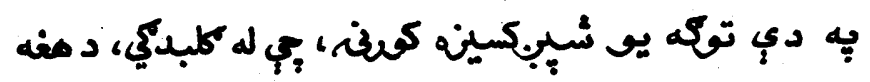

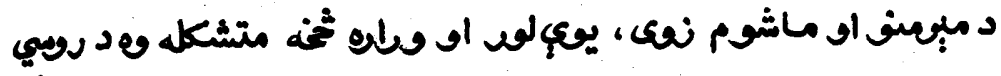

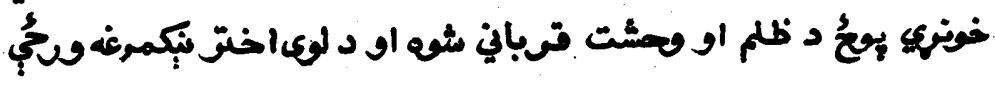

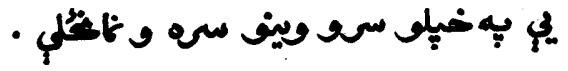



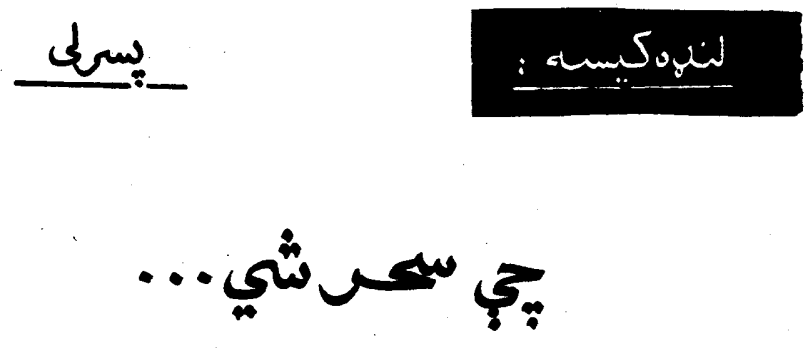

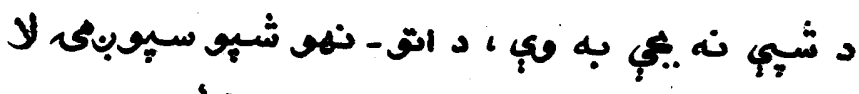

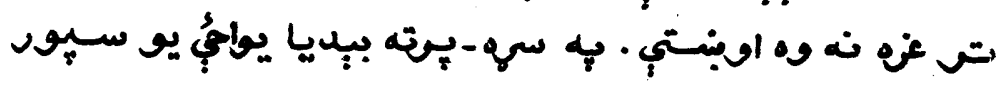

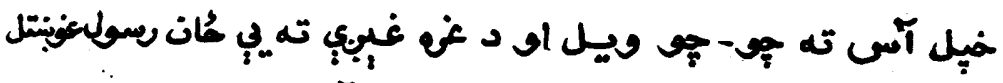

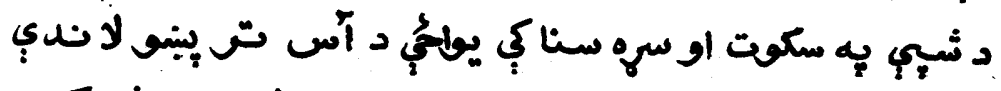

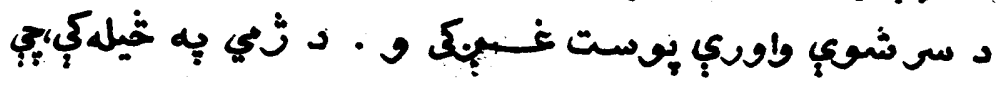

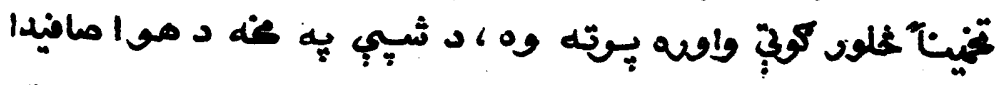

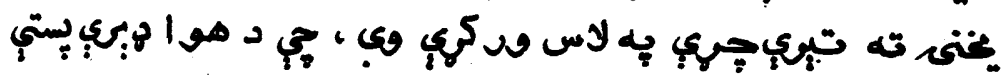

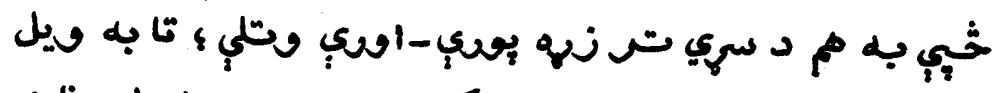

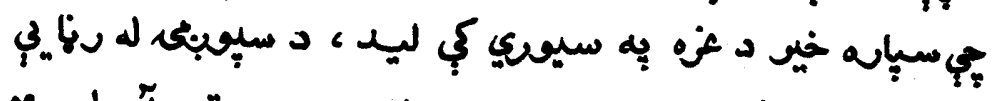

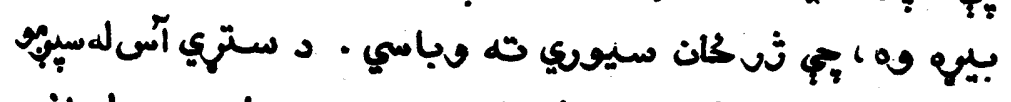

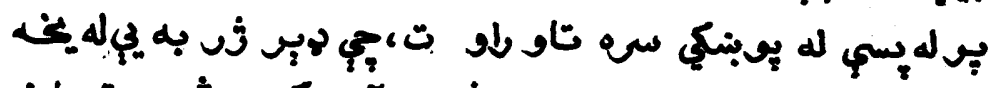

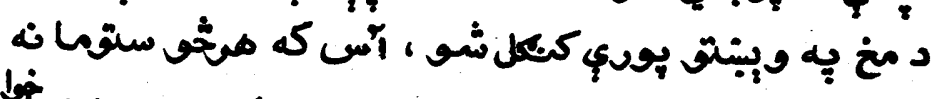

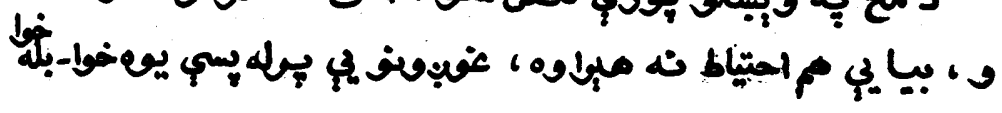




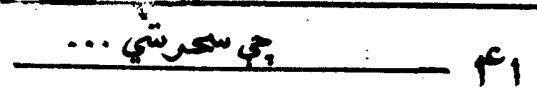

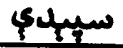

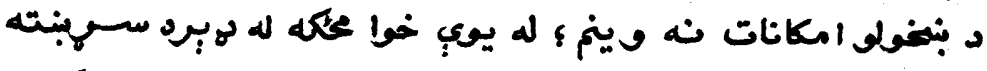

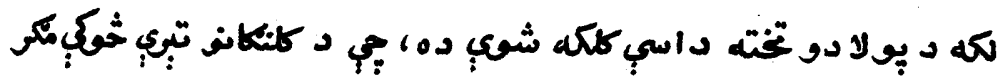

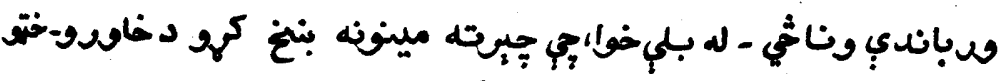

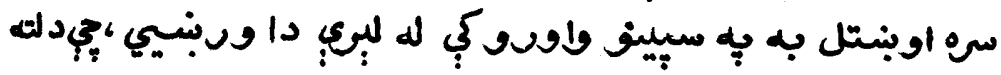

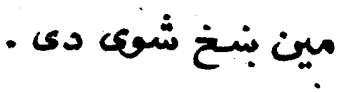

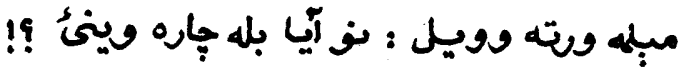

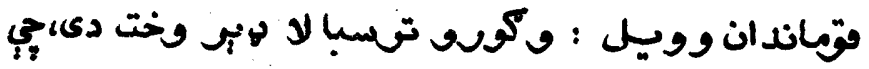

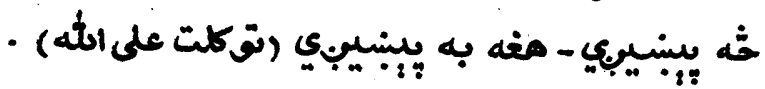

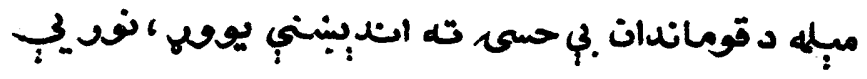

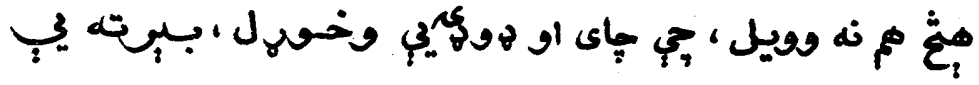

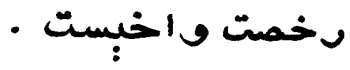

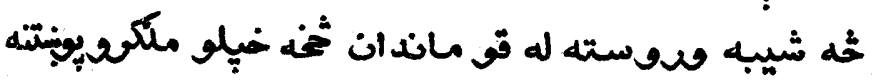

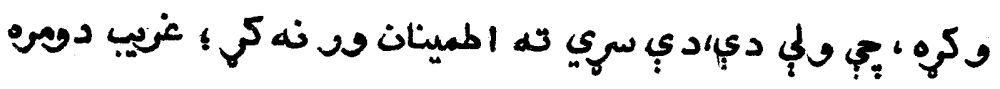

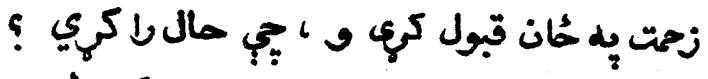

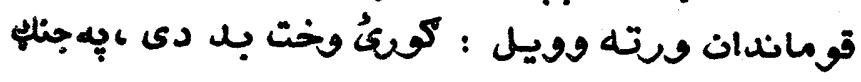

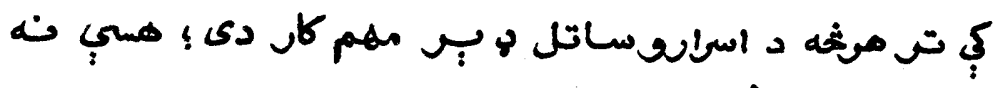

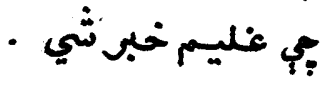

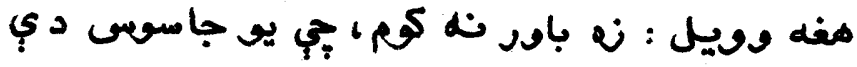

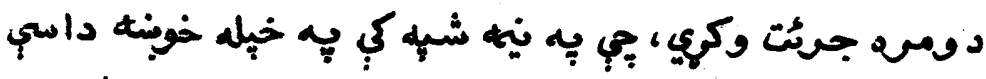

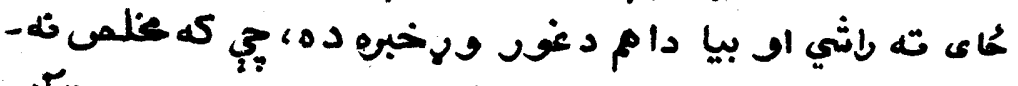

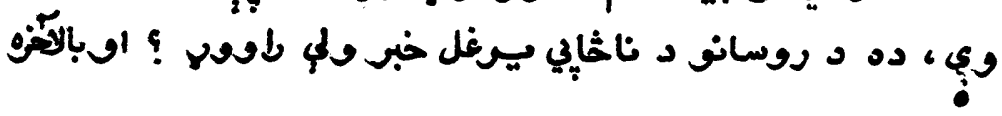




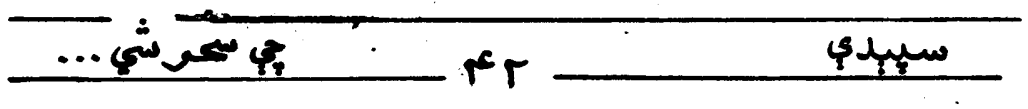

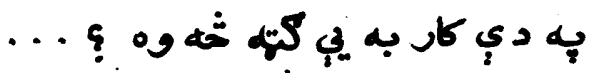

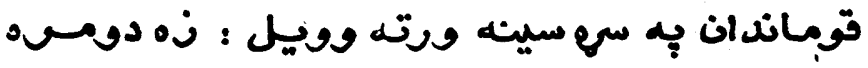

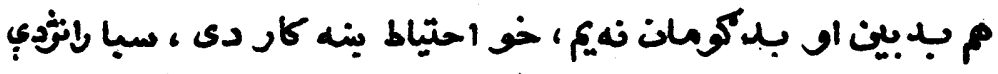

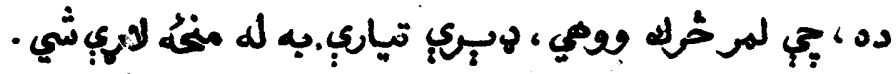

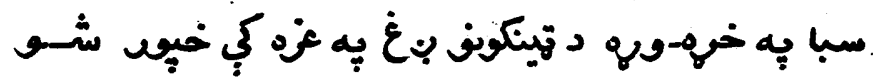

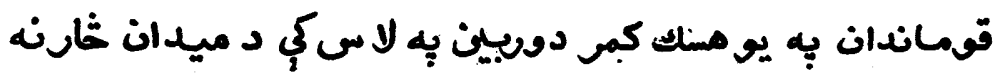

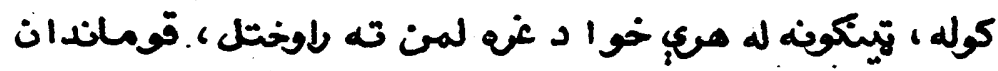

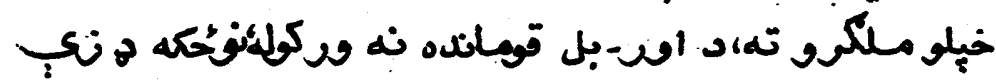

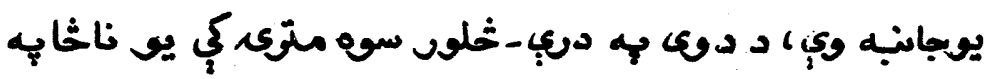

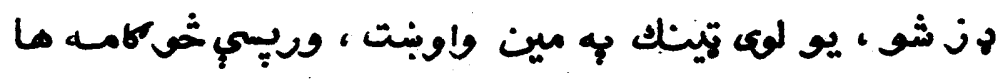

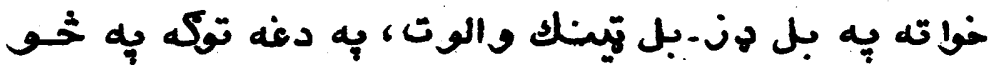

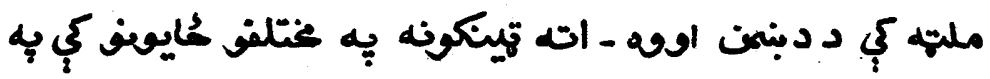

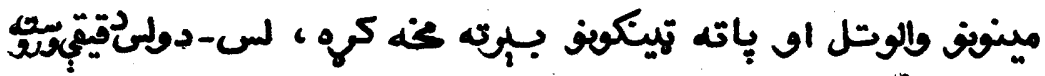

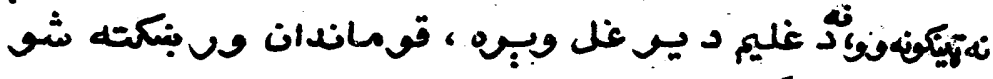

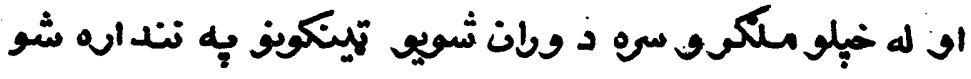

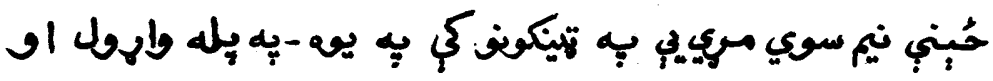

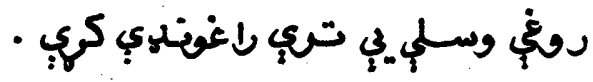

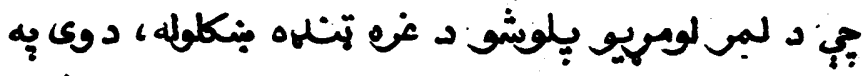

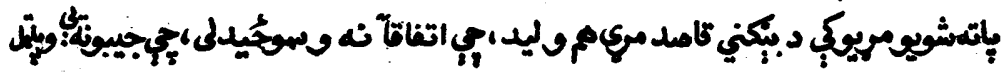

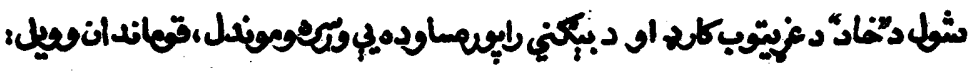

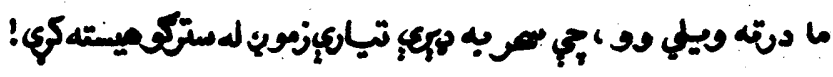


لنبرهيسه :

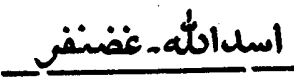

ماليوبادونه

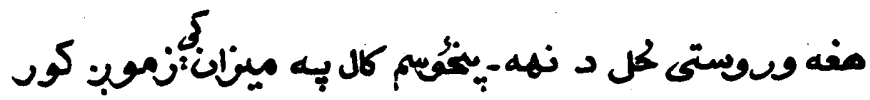

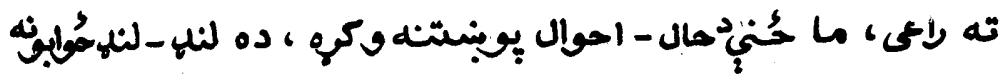

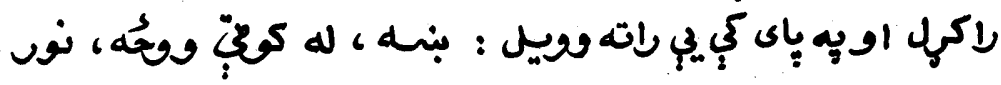

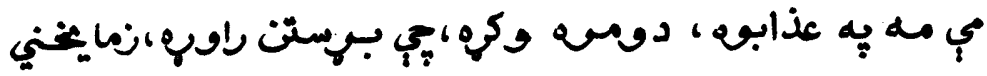

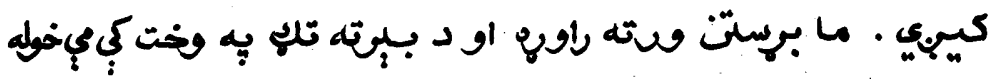

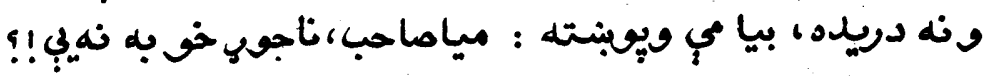

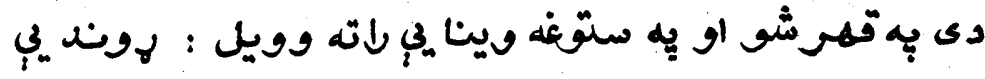

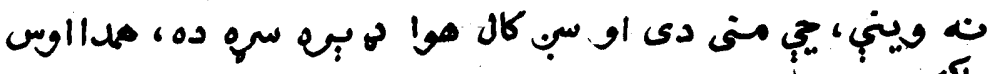

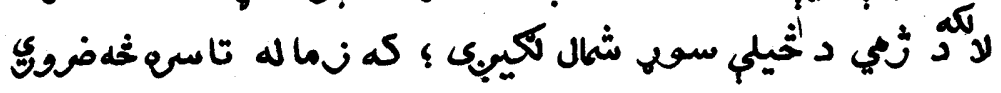

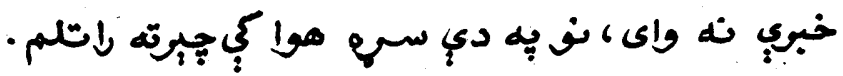

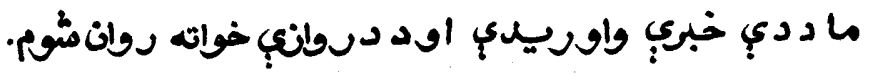

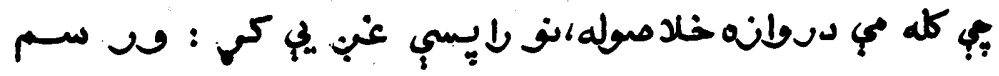

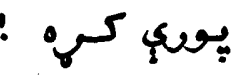




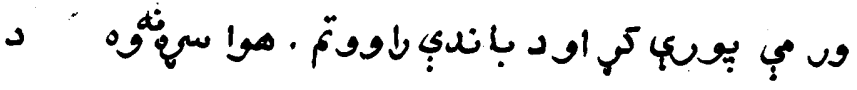

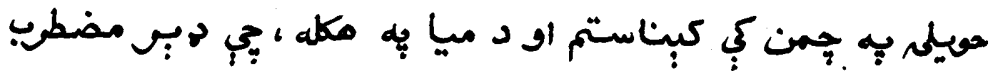

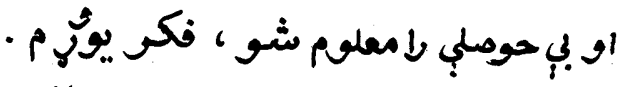

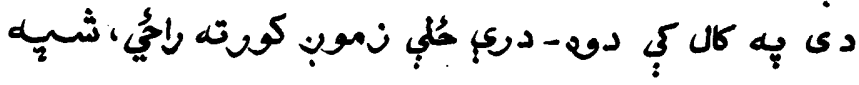

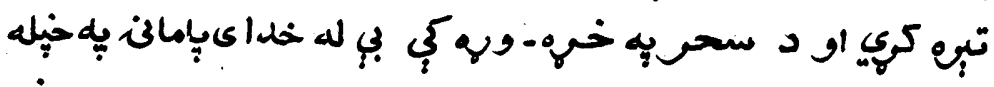

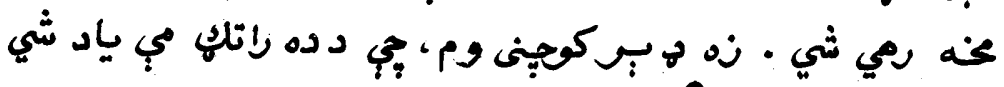

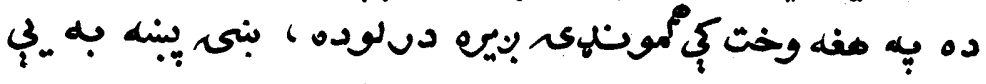

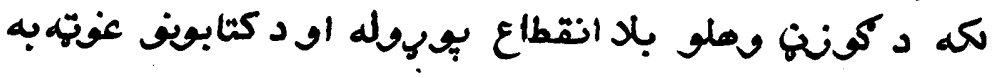

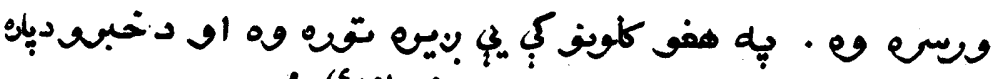

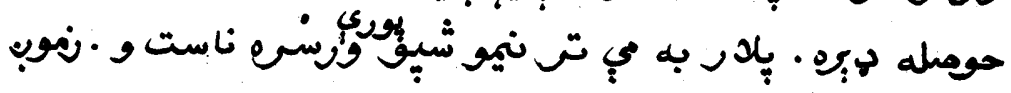

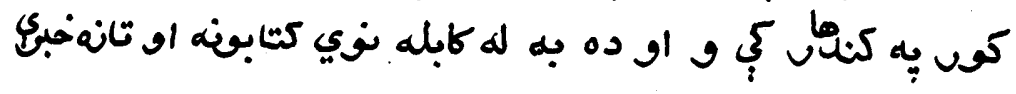

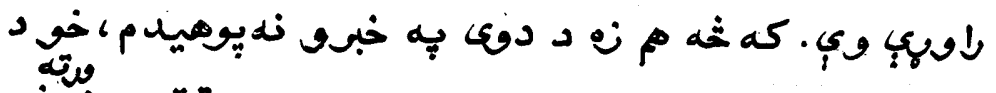

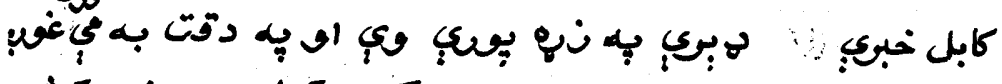

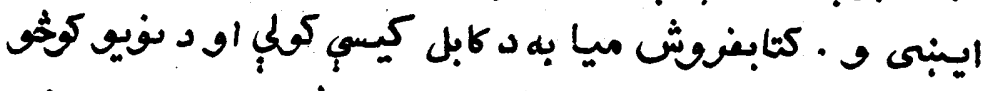

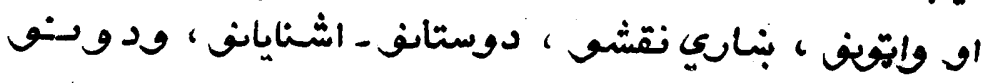

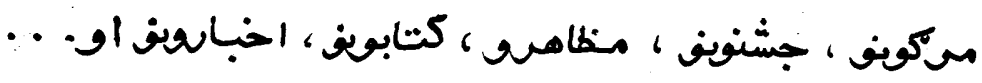

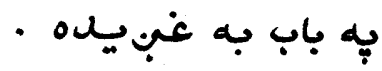

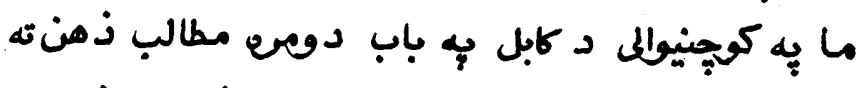

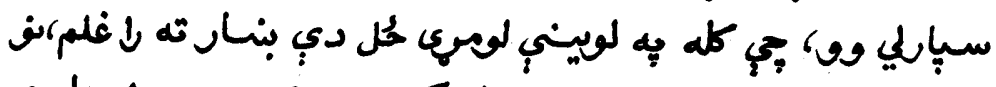

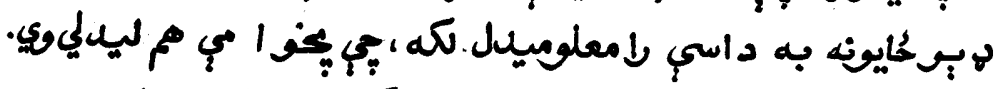

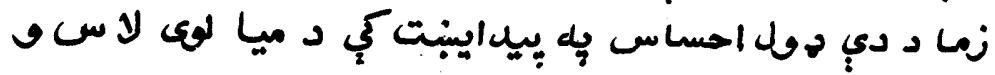




\section{ماره مباد ونه}

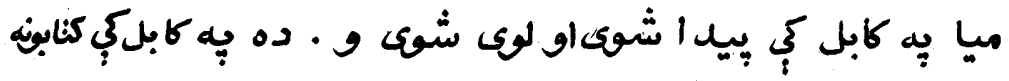

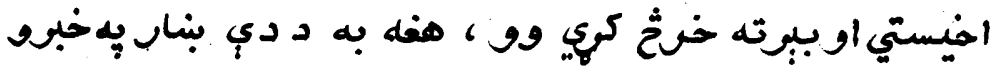

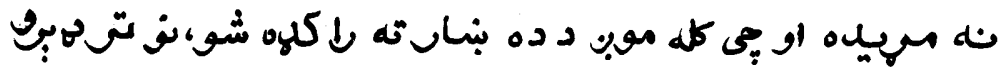

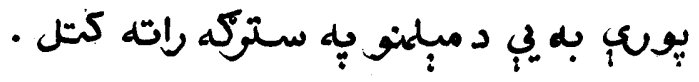

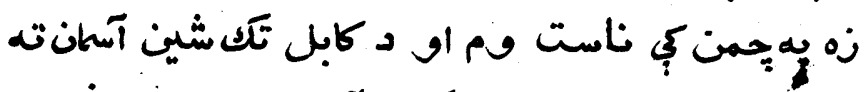

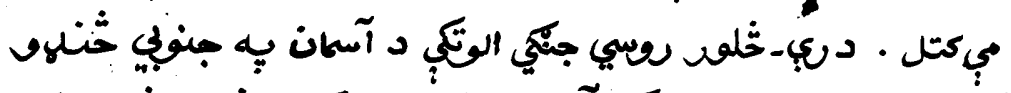

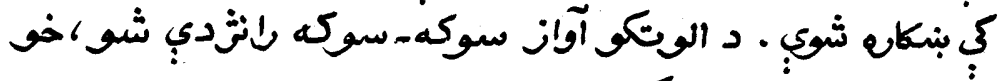

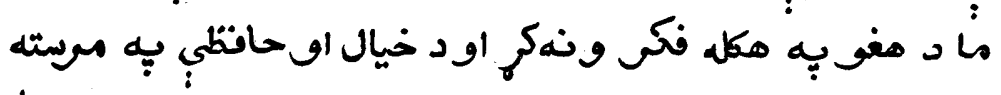

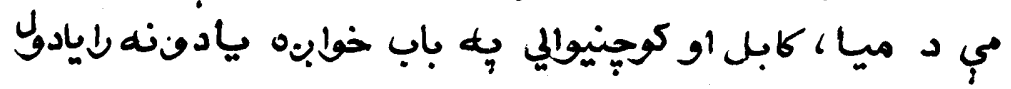

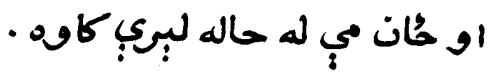

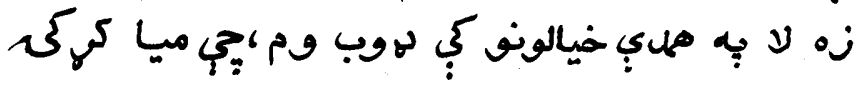

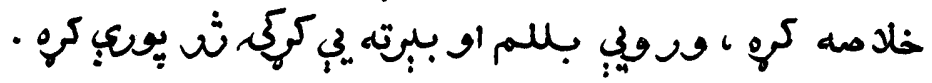

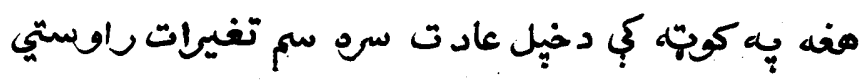

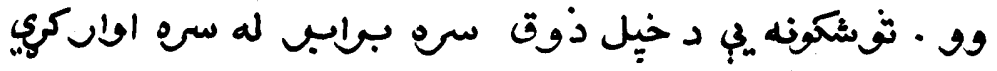

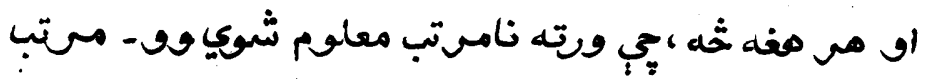

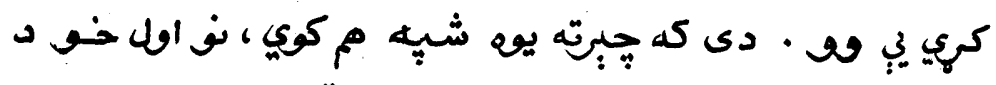

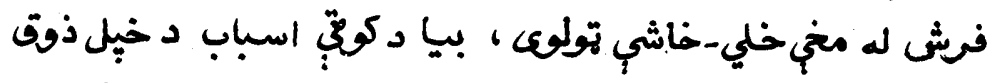

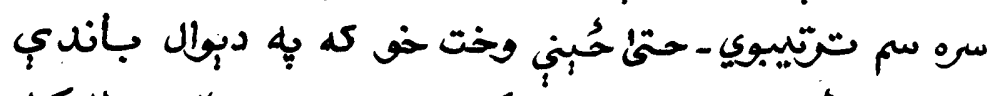

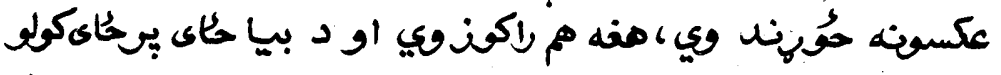

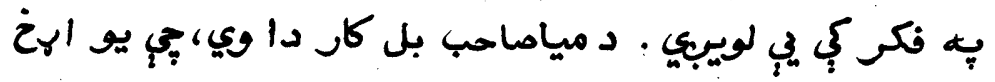

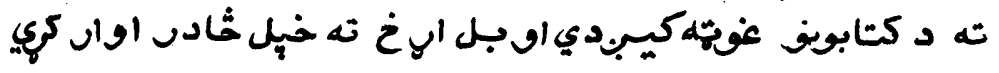




\section{سابح بادونه}

Fy

سְִִׁ

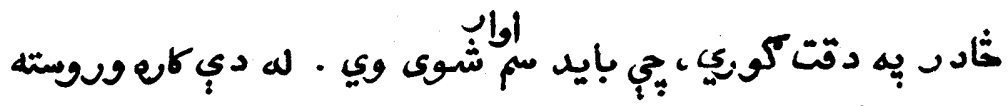

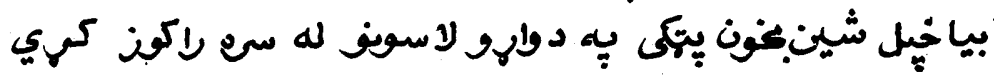

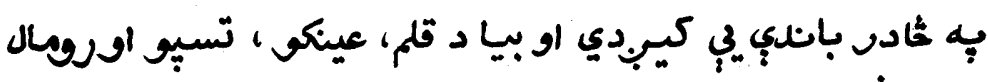

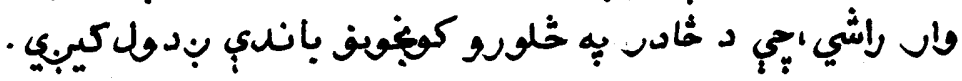

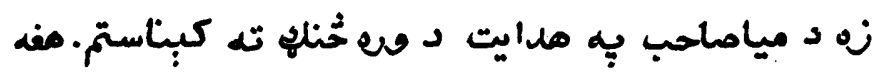

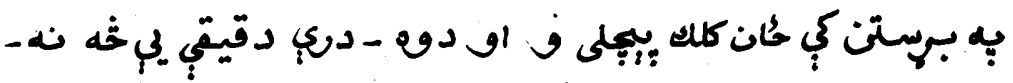

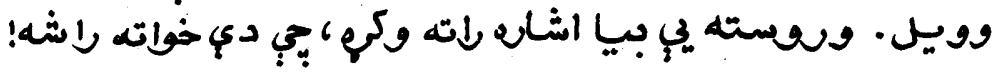

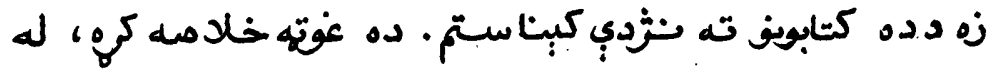

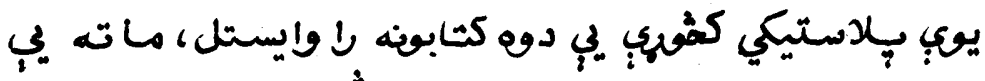

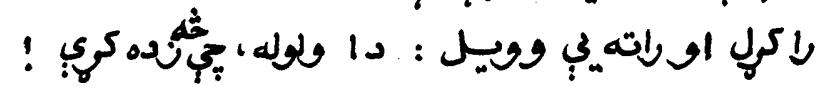

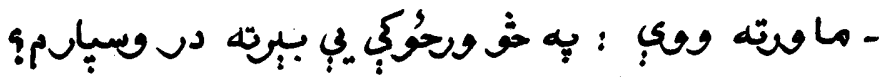

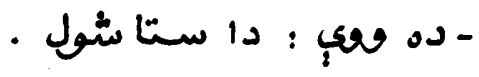

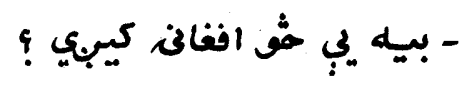

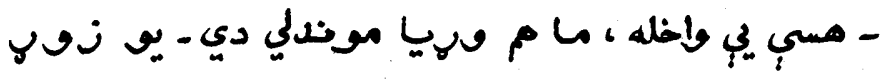

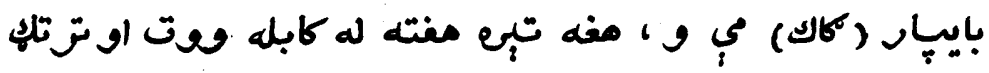

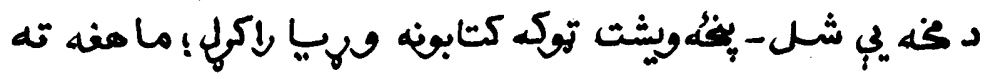

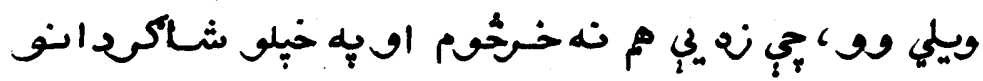

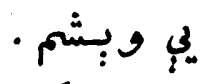

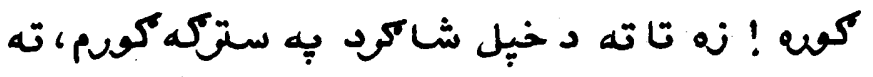

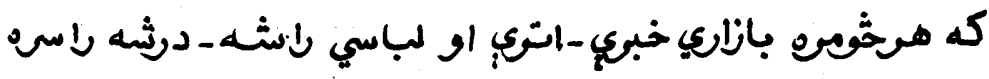

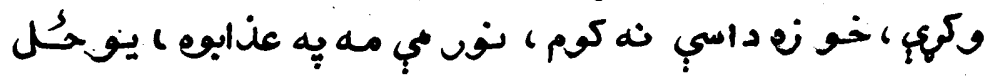




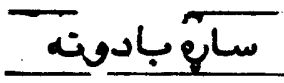

ev سبربs.

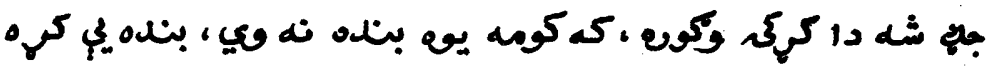

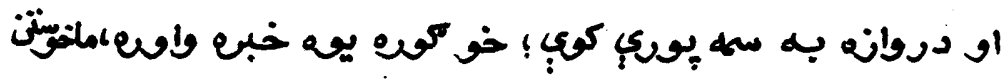

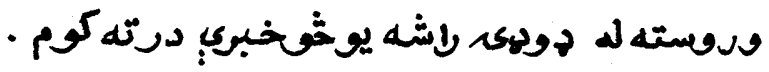

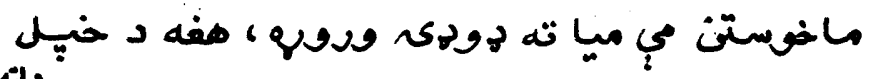
ين

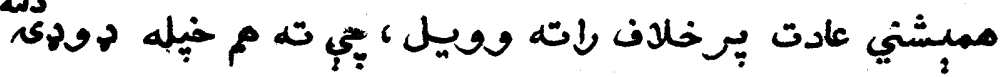

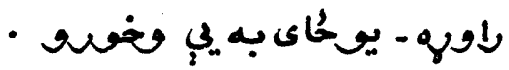

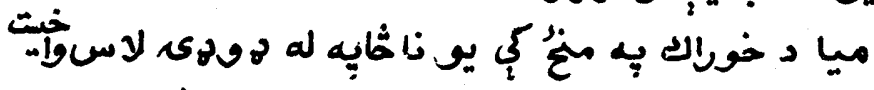

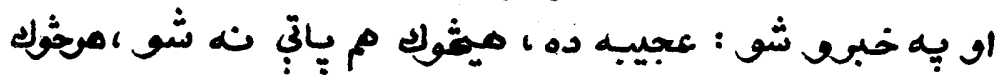

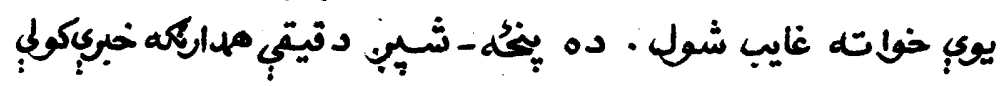

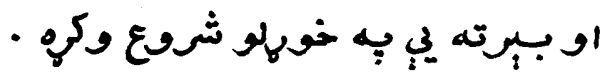

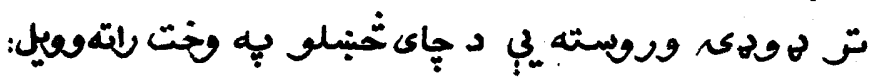

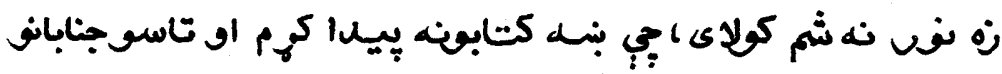

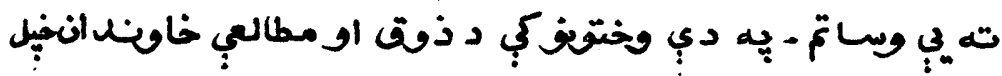

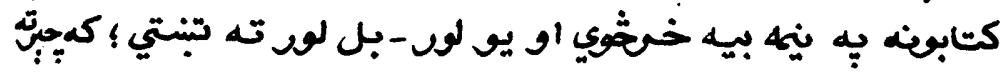

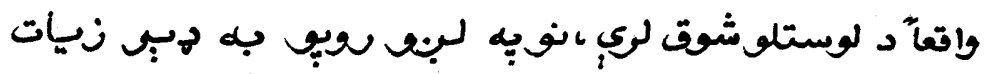

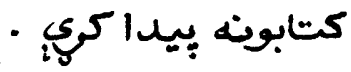

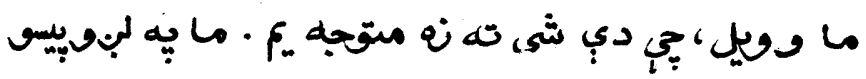

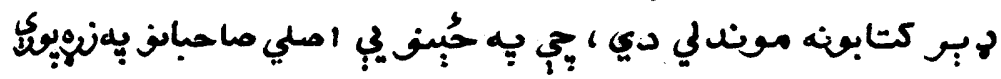

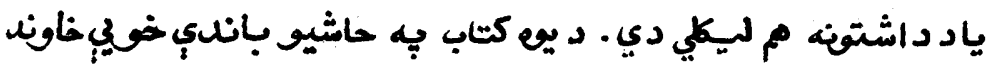

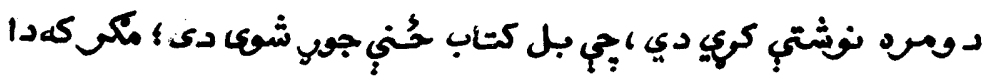

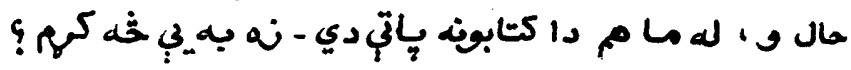




\section{سابه مبادونه}

FA

سחب سب

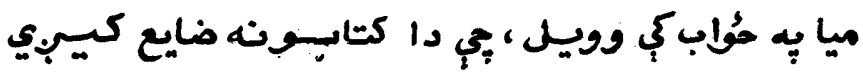

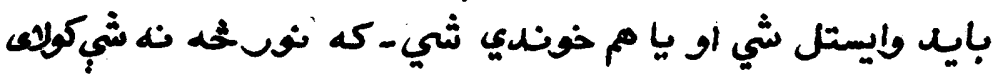

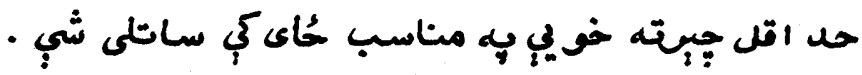

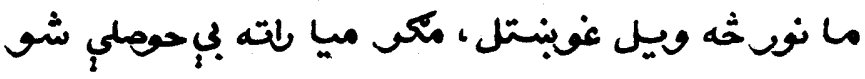

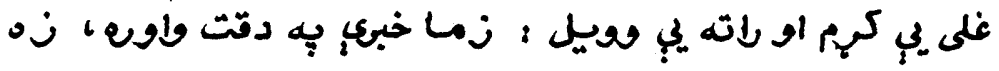

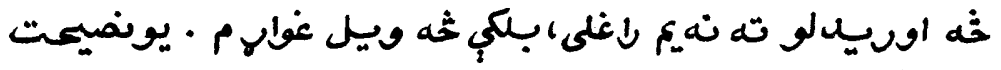

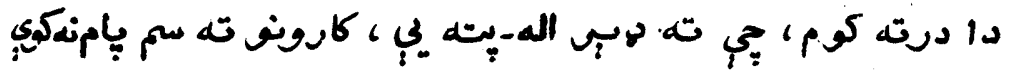

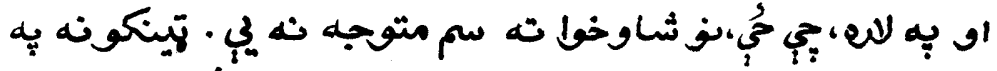

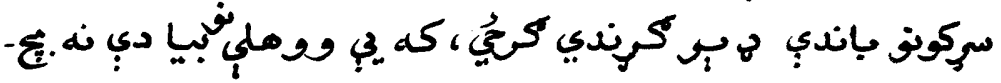

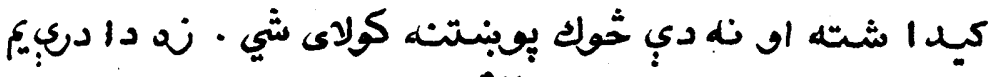

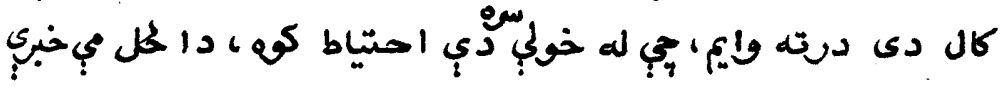

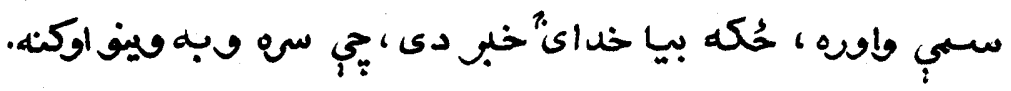

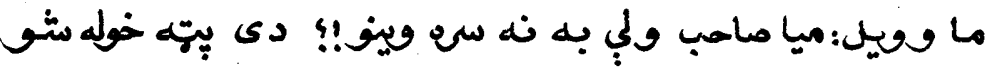

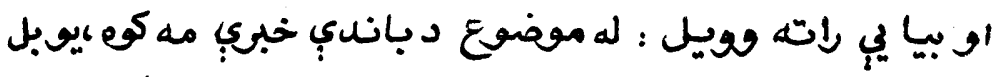

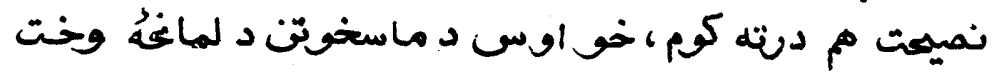

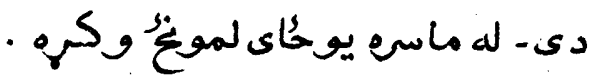

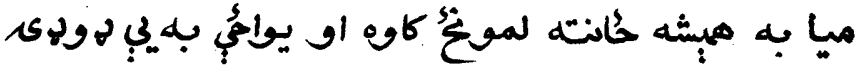

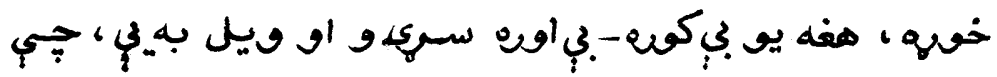

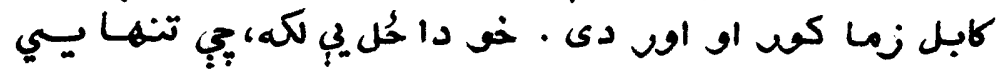

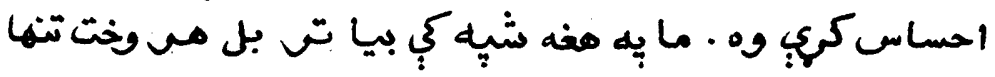
ولهن 


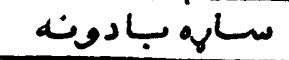

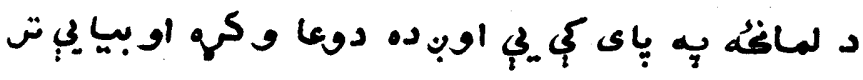

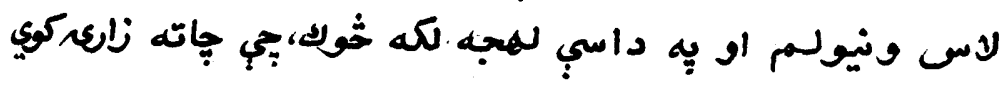

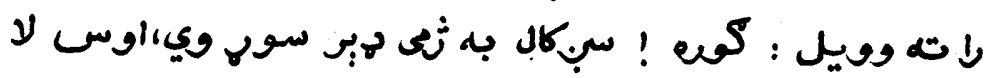

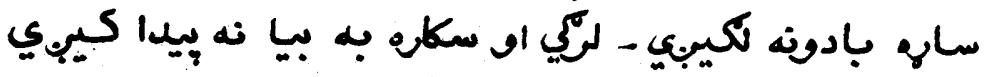

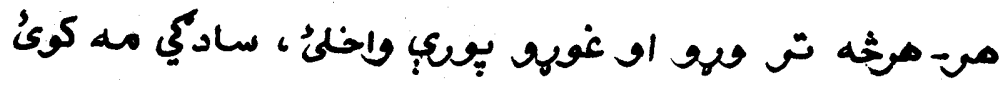

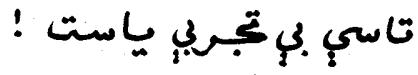

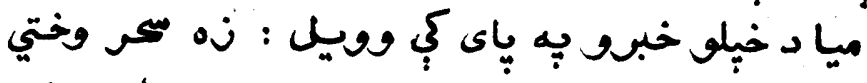

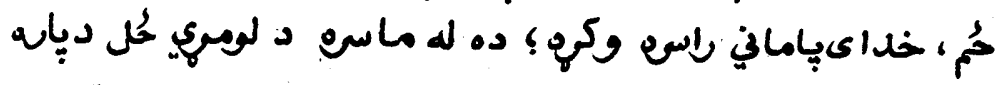

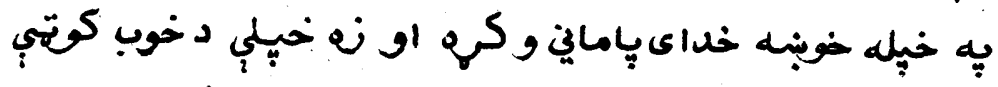

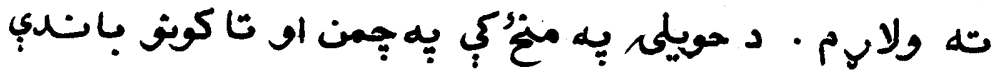

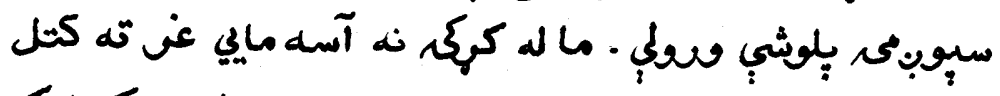

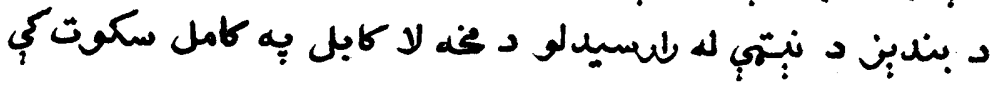

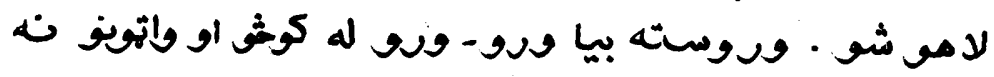

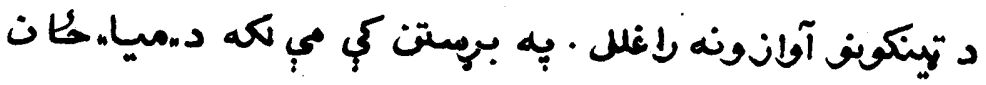

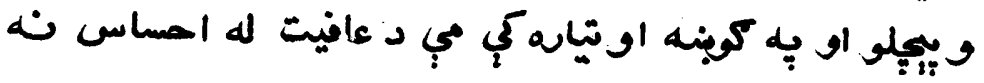

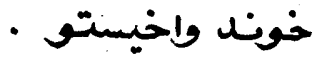




\section{زنفانخولي اديبان :}

صبي النه - رِّع

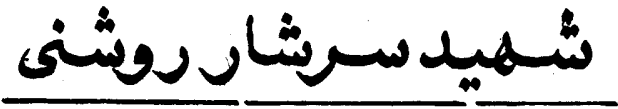
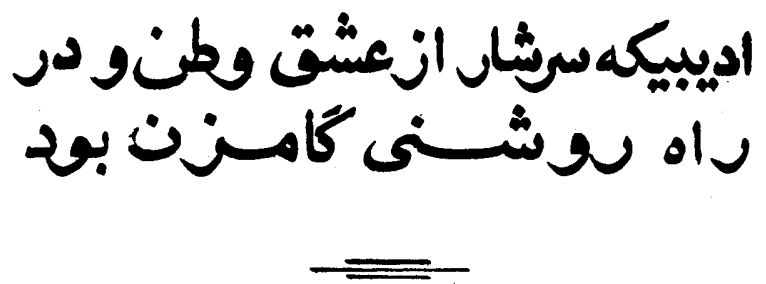

بالاتت ان جهان كسان اعتبارما ستت

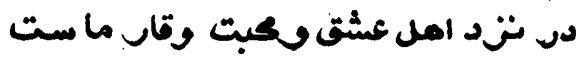

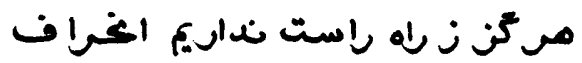

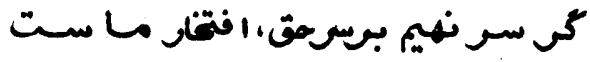

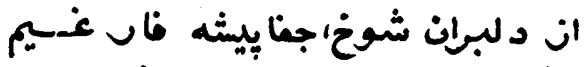

عشتى ووفا به ميهن شيرين شُعارماست

شورى اكى به سنبود ، سمجبه خمإنيث

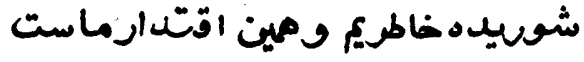


شهيد سنّار...

Q 1

سمبرك

مودن بـوى بستر ان آيين مرد نيست

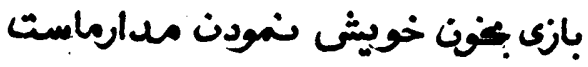

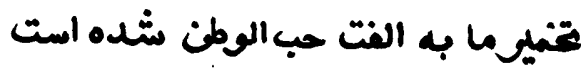

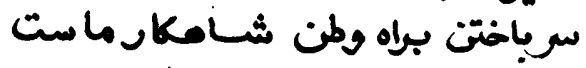

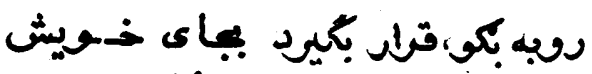

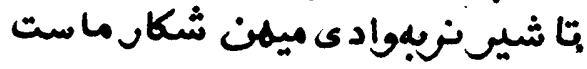

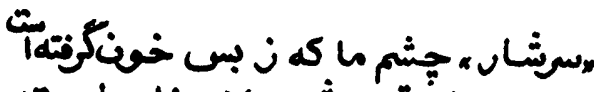

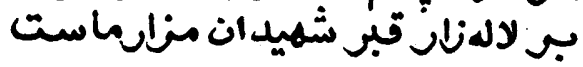

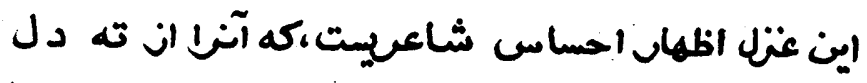

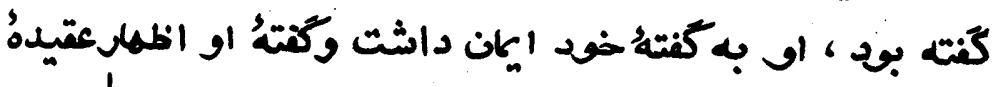

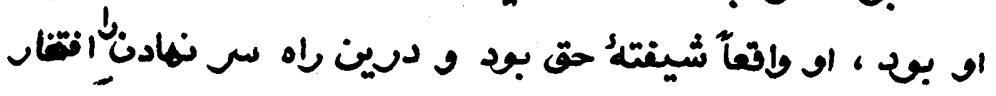

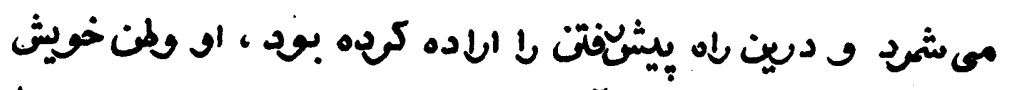

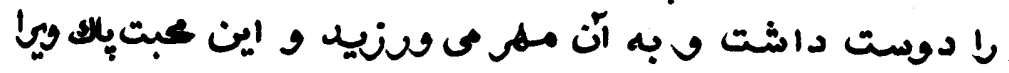

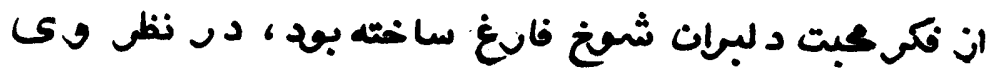

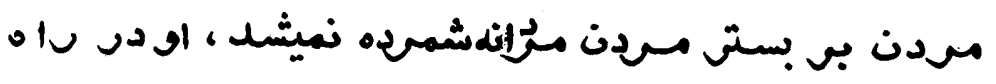

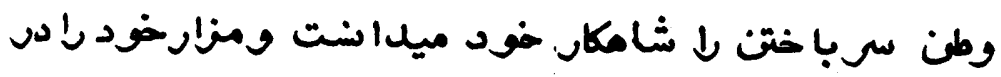

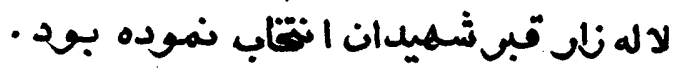

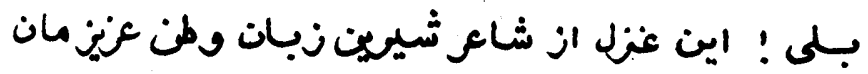

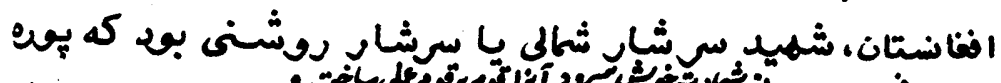

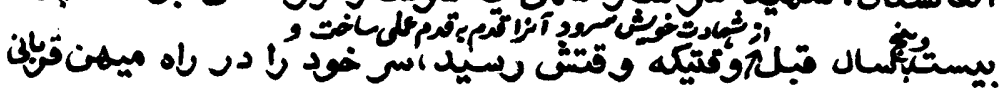




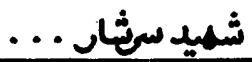

ar

سبريد

كسح و با كاروان شميدان كلكون كفن ميهن مان لام د ميكال

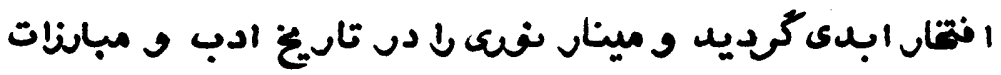

ما بي كذاشت .

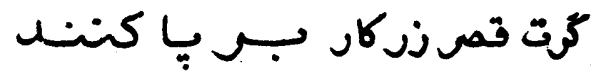

درونش ستون مـطلا كنـن

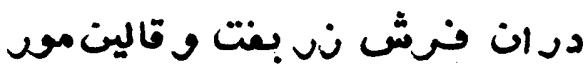

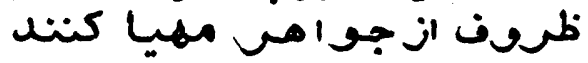

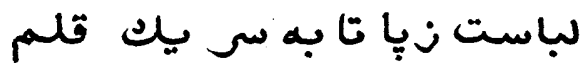

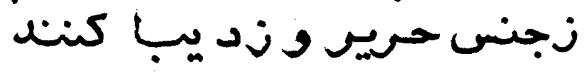

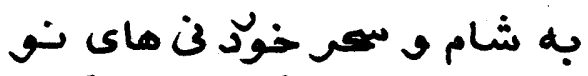

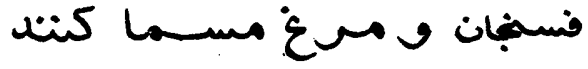

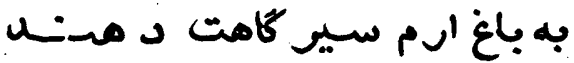

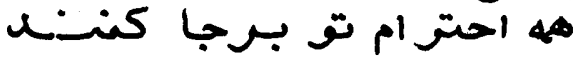

به كلامت الماسى وفيدونه نصب

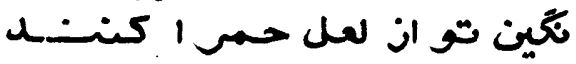

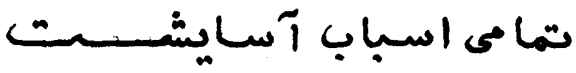

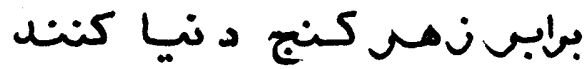

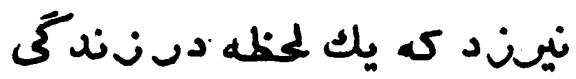

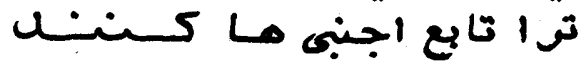


ع منئ.

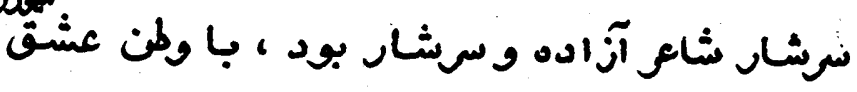

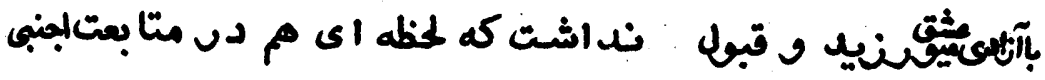

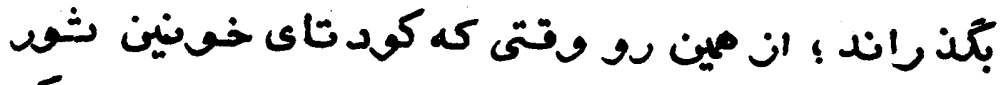

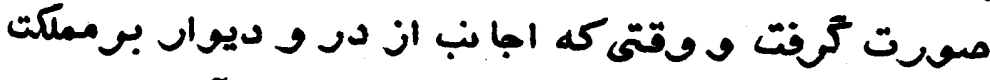

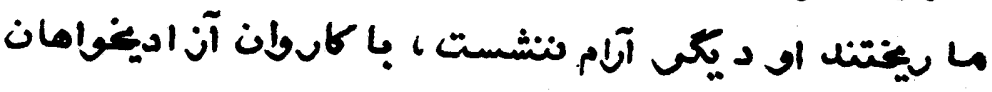

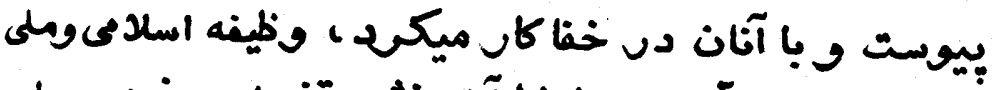

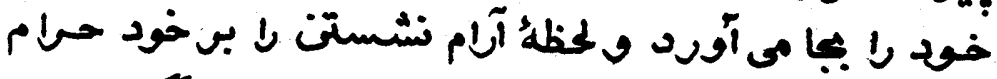

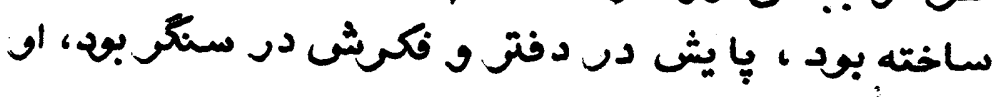

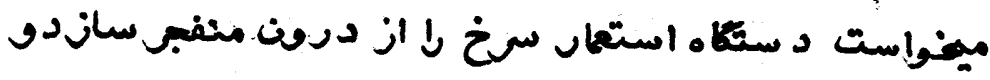

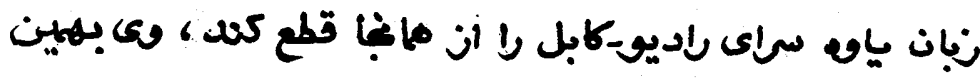

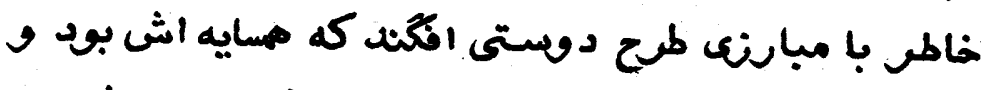

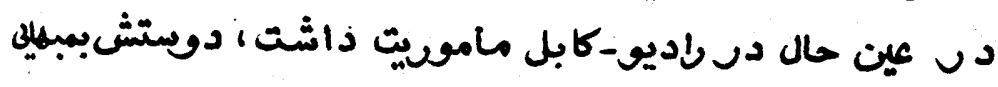

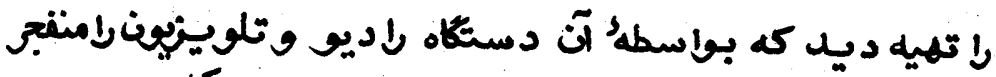

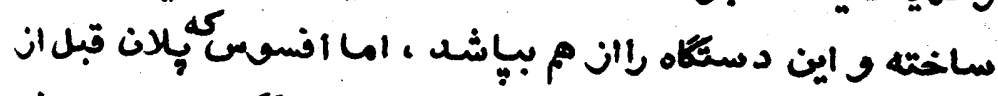

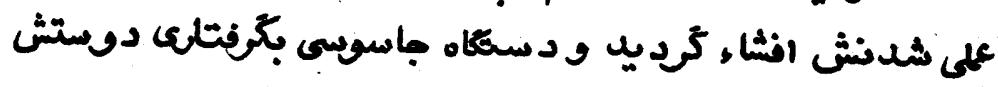

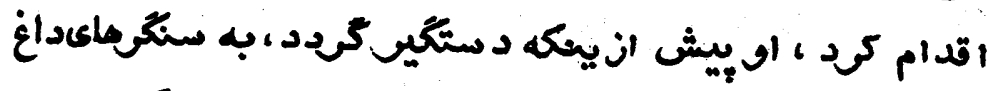

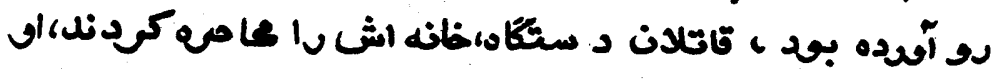

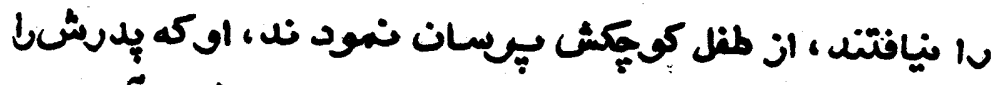

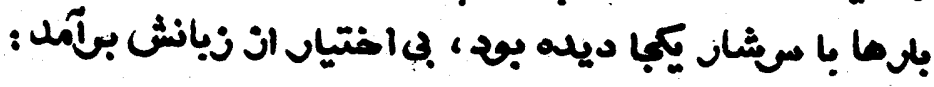

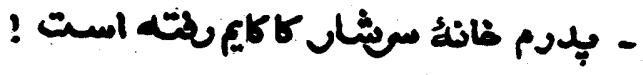

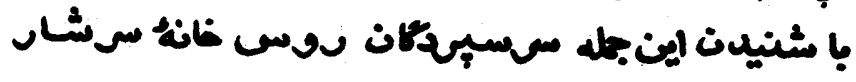


شهيدسشار...

or

سيبدي

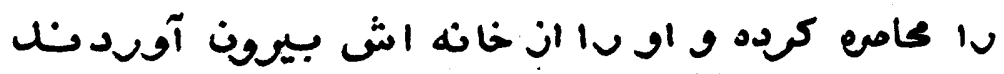

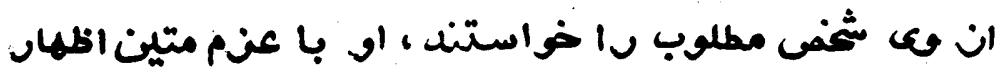

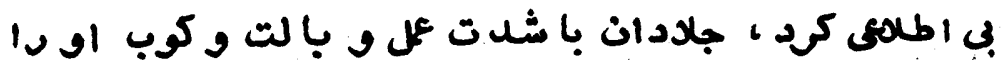

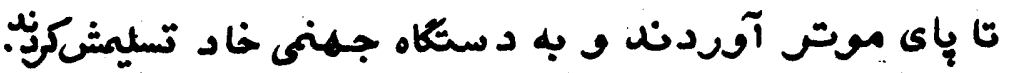

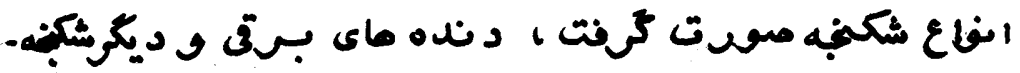

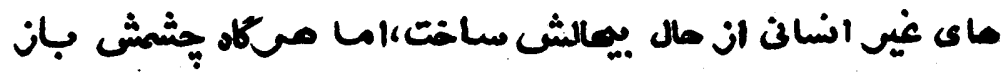

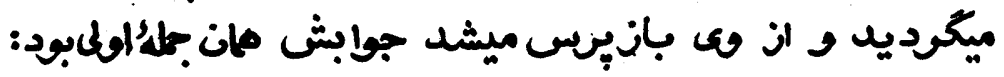
ـ من خبرندارم ؛

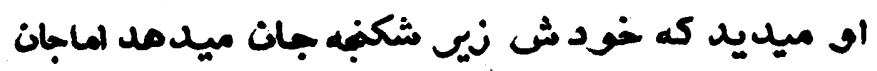

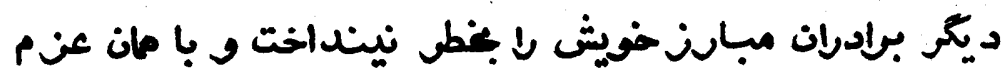

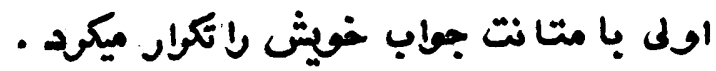

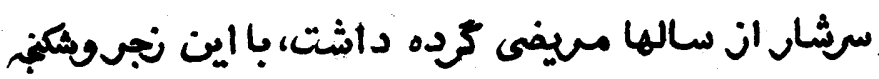

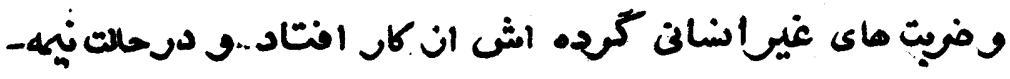

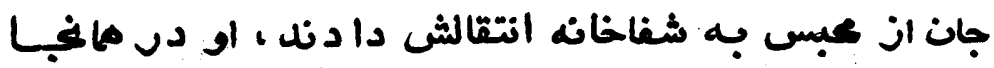

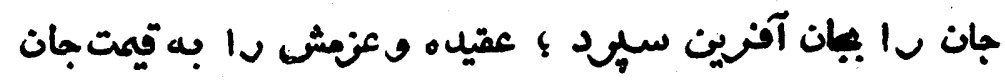

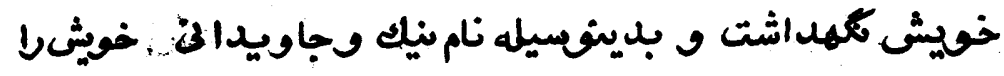

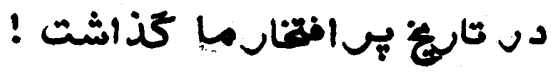

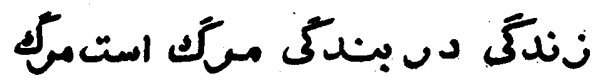

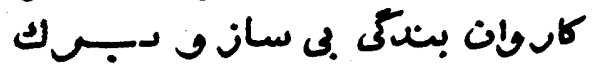

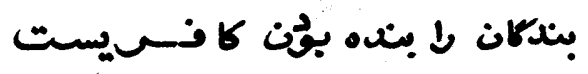

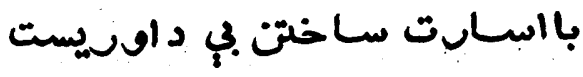


شهيدسمشار... D $ه$ سيبدي

أه بسآزاد تن هبوسف حبان

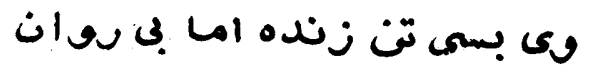

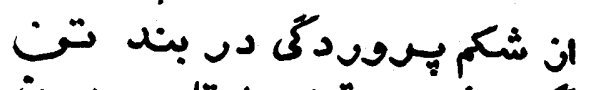

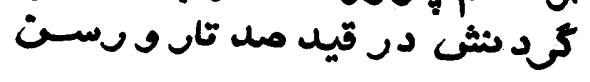

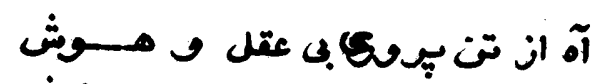

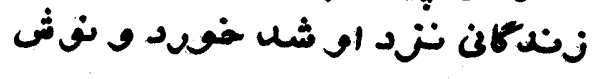

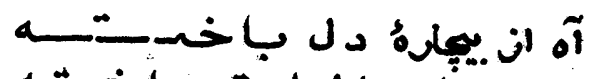

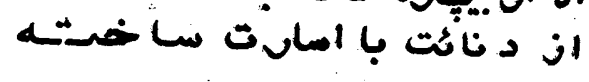

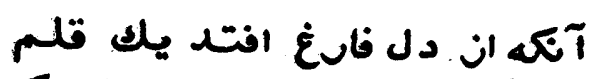

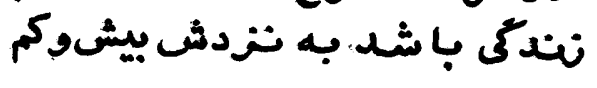

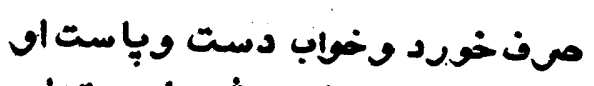

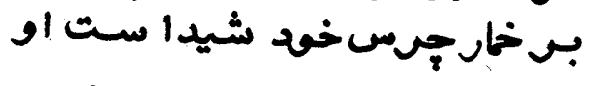

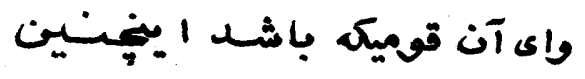

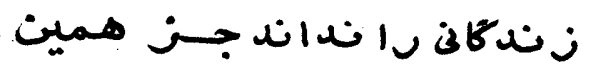

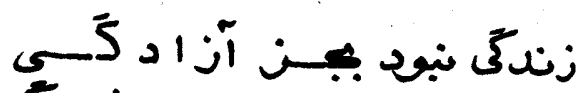

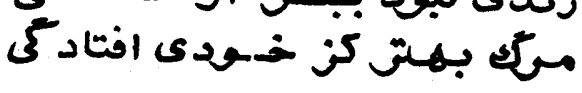

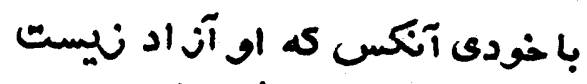

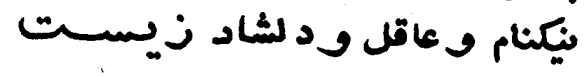

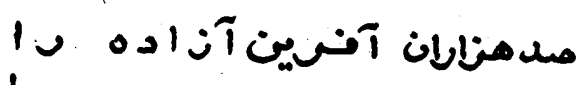

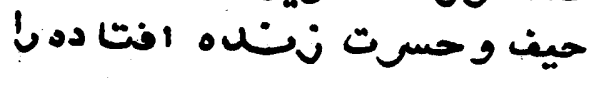


نزد من مركس كه آز اد است أو أو او

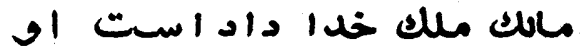

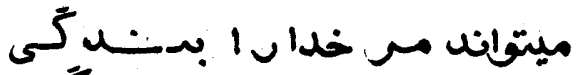

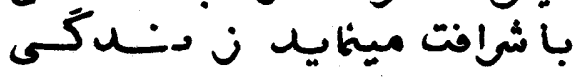

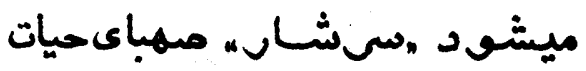

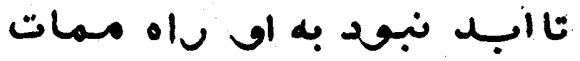

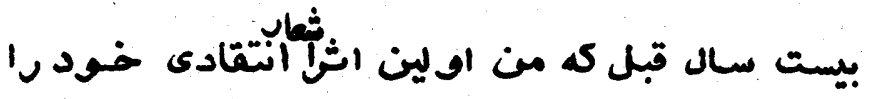

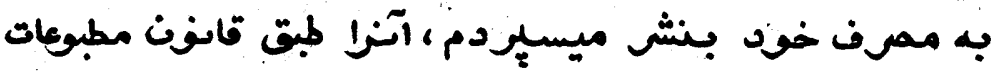

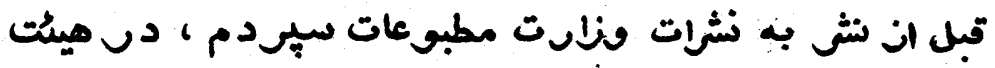

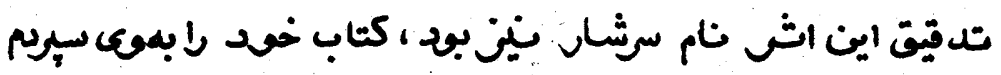

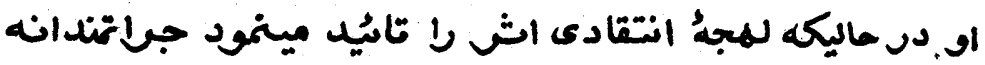

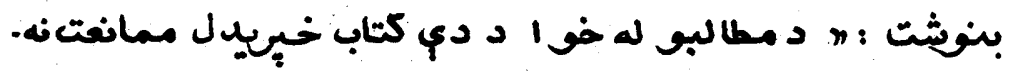

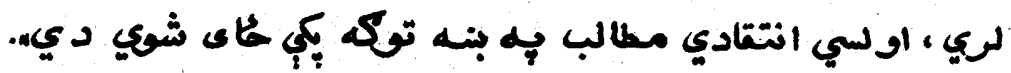

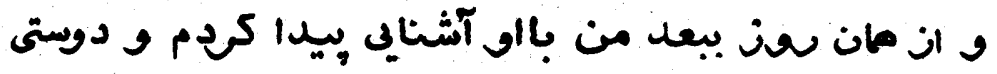

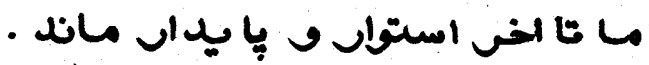

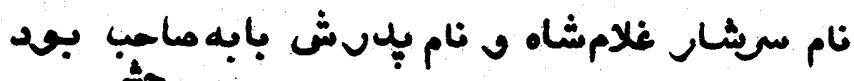

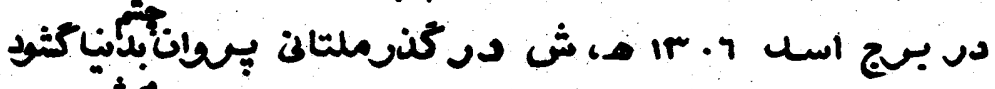

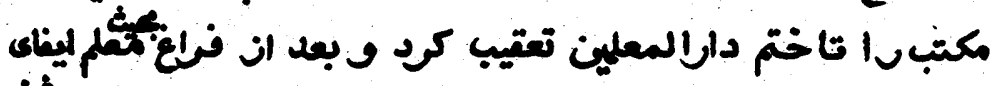

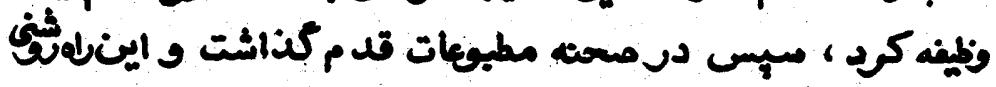

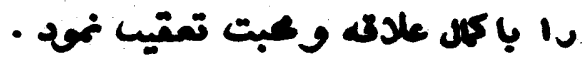




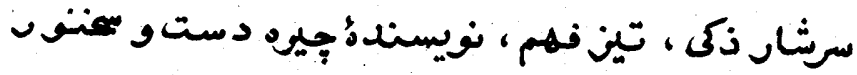

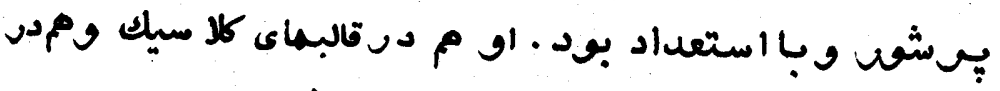

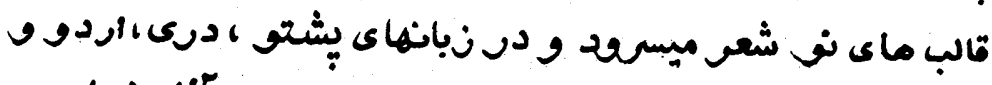

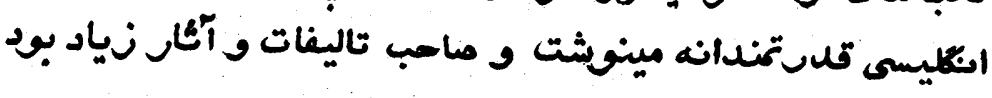

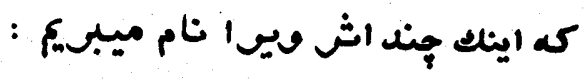

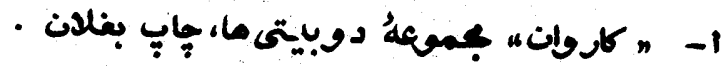

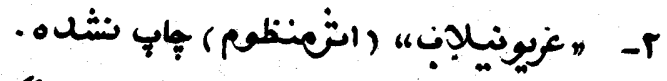

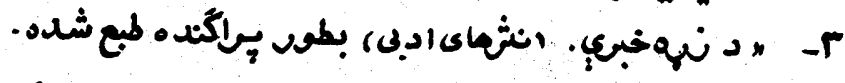

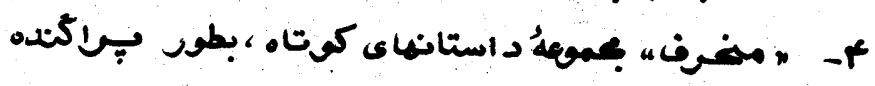
- لكع شـــ

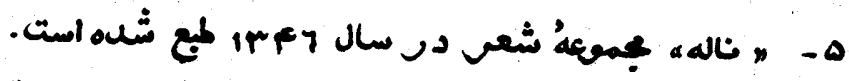

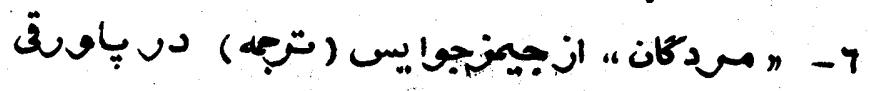

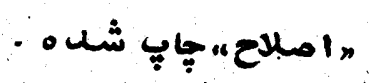

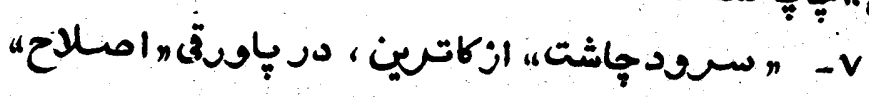

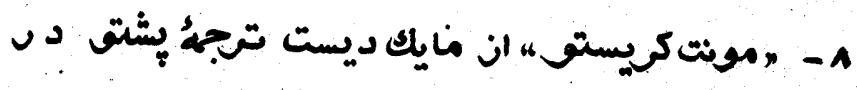

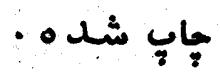

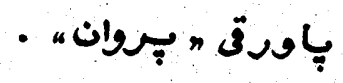

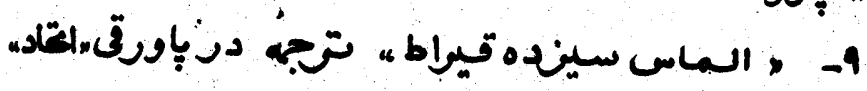

نش نشفه امست 


\section{انزونها و ناشتا \\ هو مس ناتمام و ســـ امل \\ $+\quad *$}

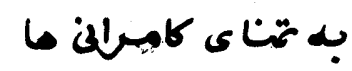

نلك باشـ تلاش ون

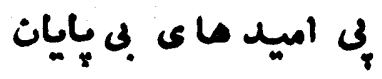

كه نيايب ومال شامد فت

بهكث امل الرن في آمان

$* *$

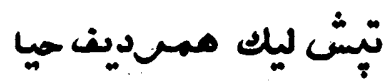

كه ن رخ آب مسنى نـبد

كه هل ف كا كسى بـعتل شئن

كى بميرد به زندكى تِّرد

***

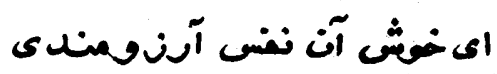

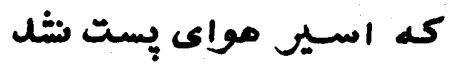
كه د لشت ان شكست ها نشكست

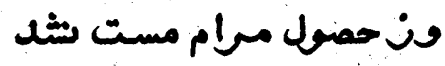




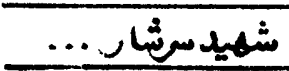

$\Delta 9$

سيمدي

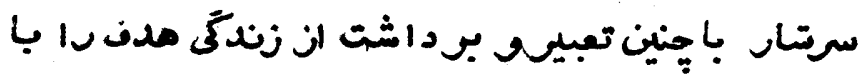

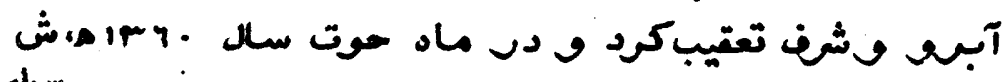

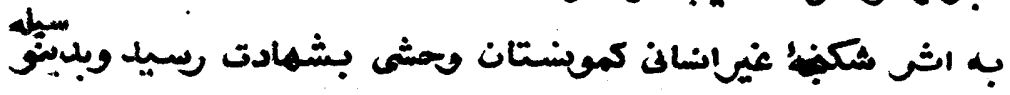

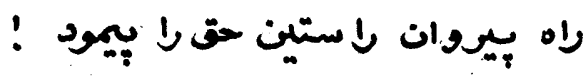

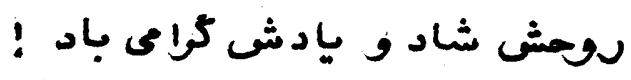

يادآصع:

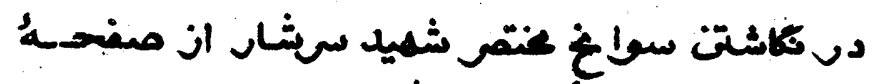

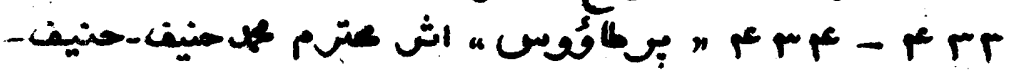

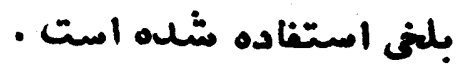

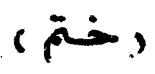

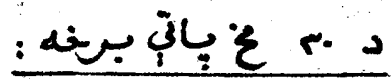

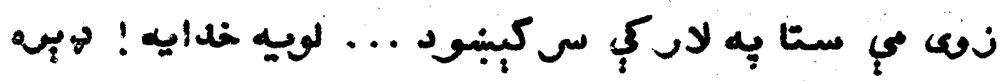

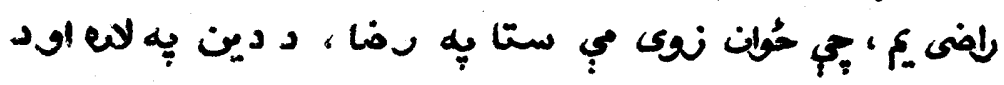

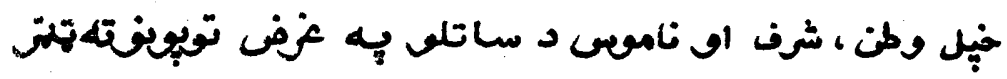

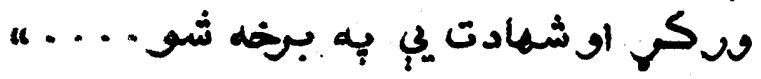

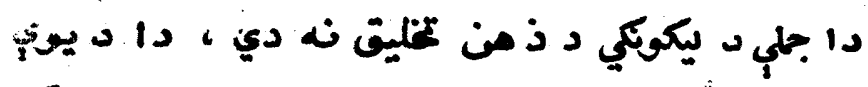

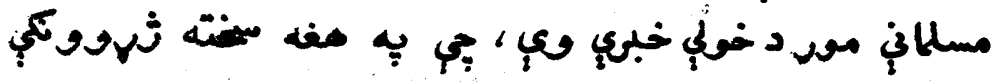

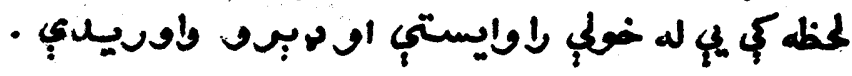




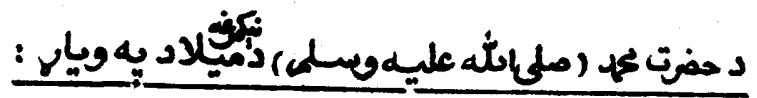

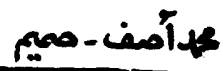

نتنبلنِدى

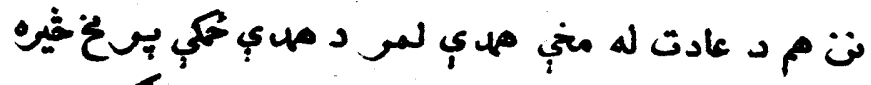

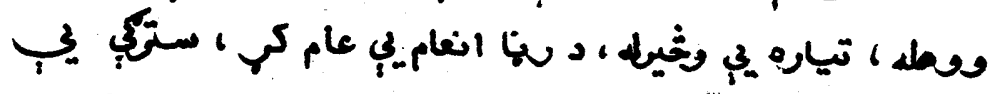

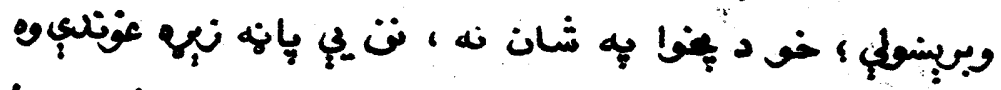

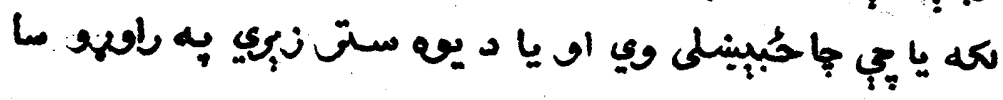

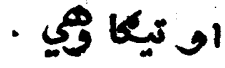

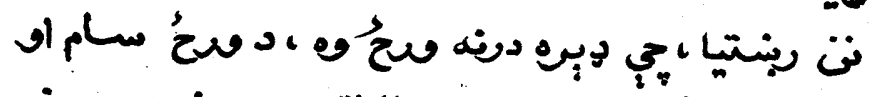

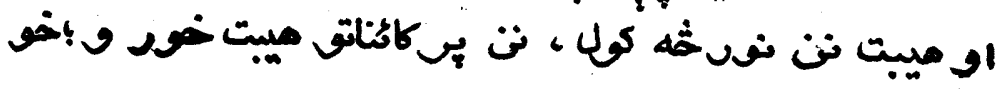

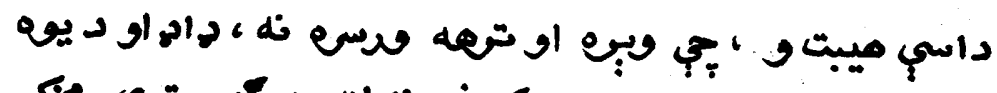

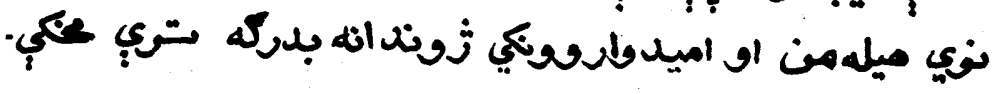

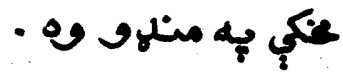

نت

ألضهى مشيت له قويج نه نمل ته لاصوت .

نن 
تتبل ...

71 سمبدي

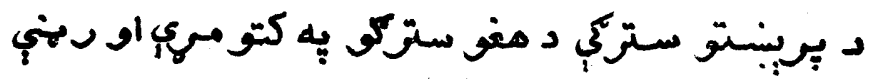

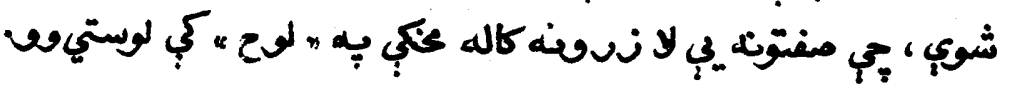

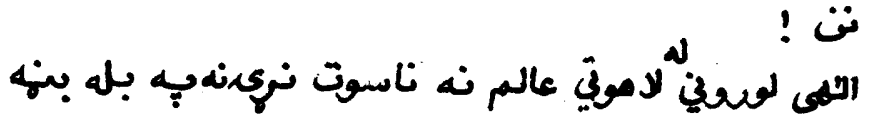

•

ن

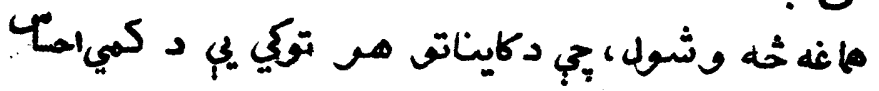

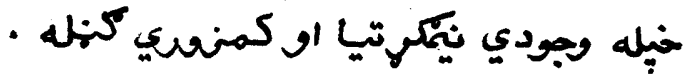

نن

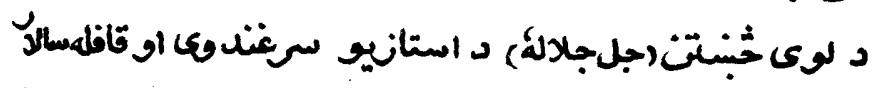

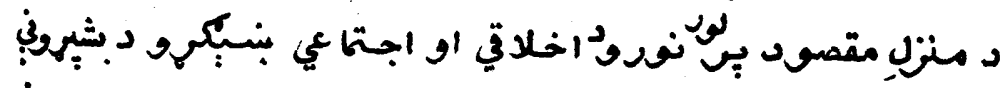

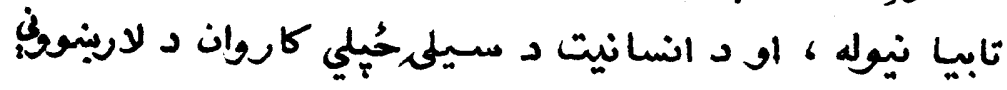

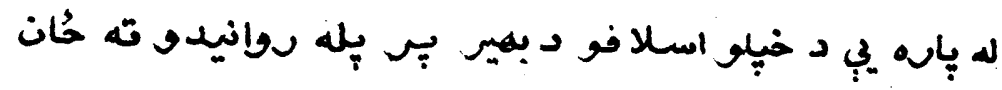

مساقده

نت :

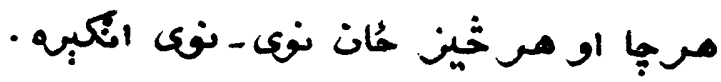
من .

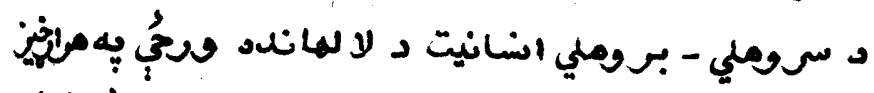

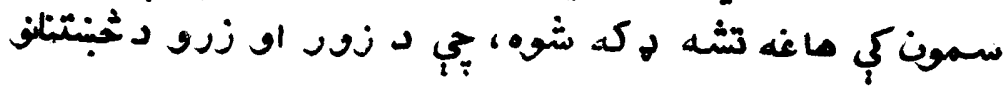

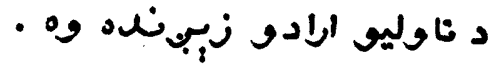

نن : 


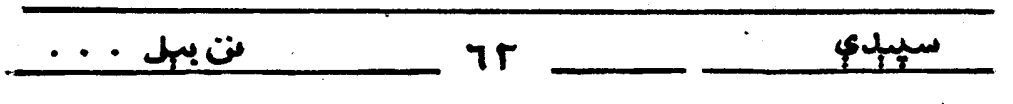

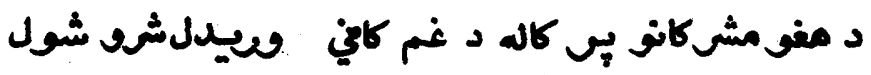

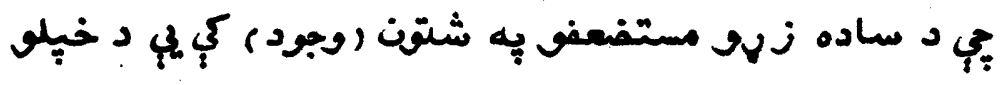

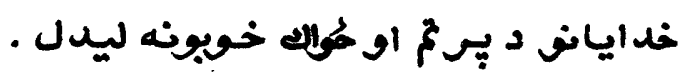
نن !

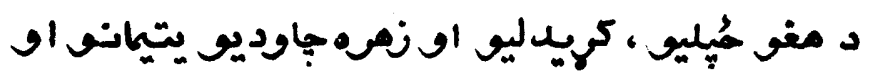

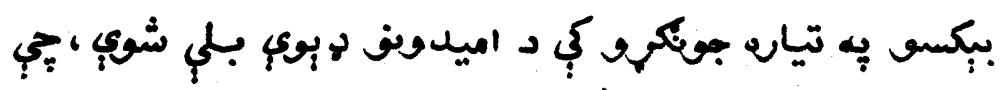

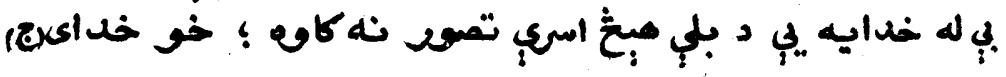

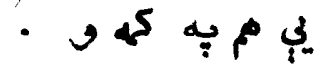

نت

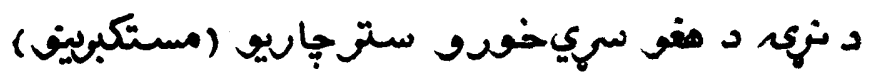

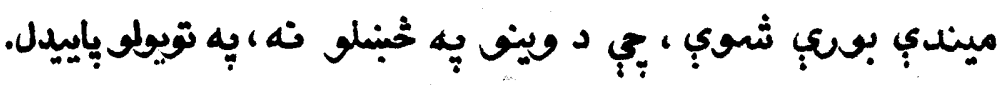
ن

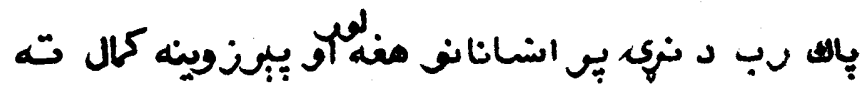

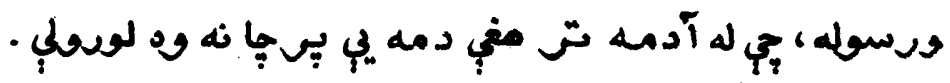

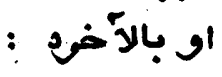

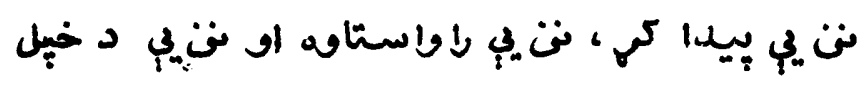

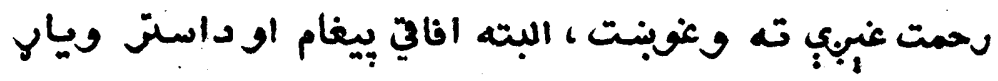

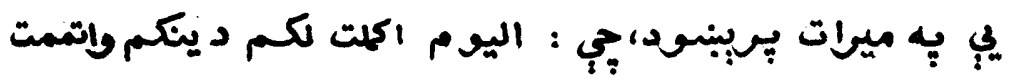

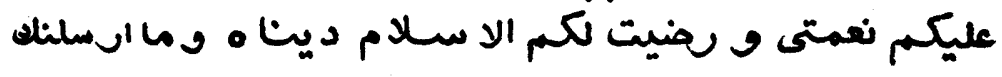

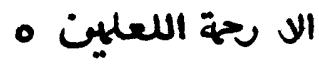

ملف أليه و سلمور المبليكا 


\section{لـنى}

: د شوصويانف عسكى لا يب وركوينه

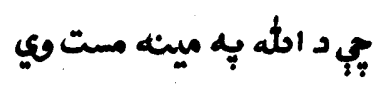
بي د روبانف به مورجيو ورتقب كوينه

$$
\text { مسلمانان به كاميابيسي }
$$

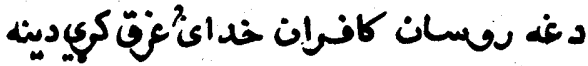

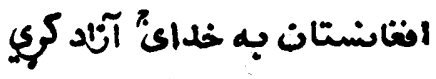
تل خفيه نه وي سه روسان اوداطلمونه

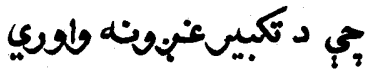

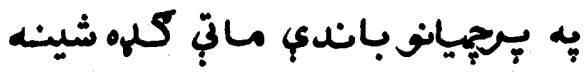
جهاد به ملته منغ وكري

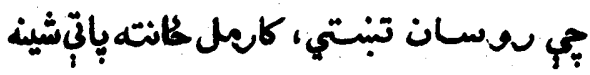




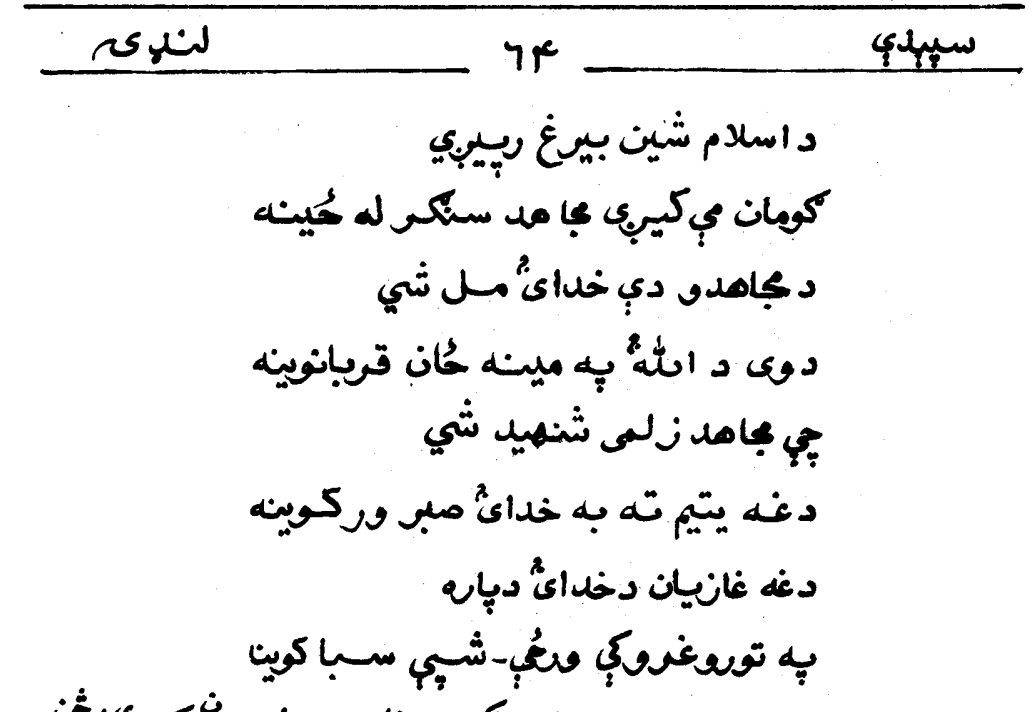

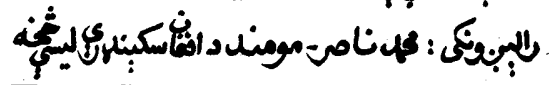

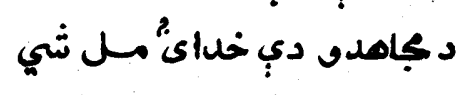

دوي د ان

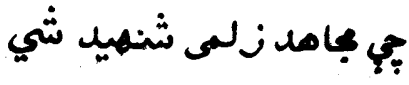

$$
\text { دغه غانيان دخدائ دياّه }
$$

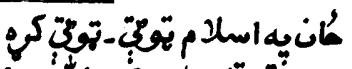

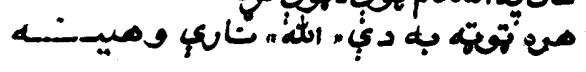

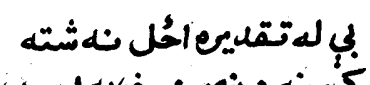

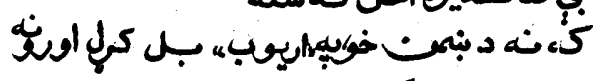

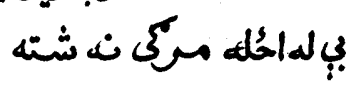

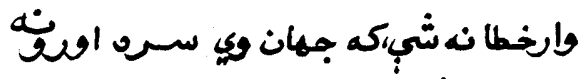

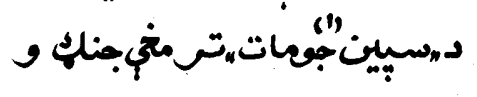

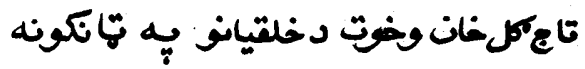

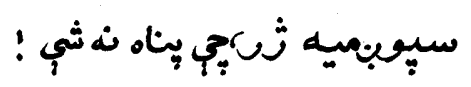

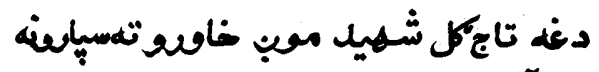

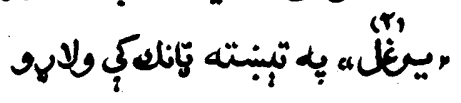

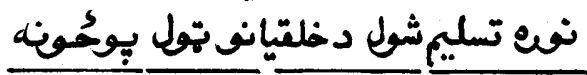

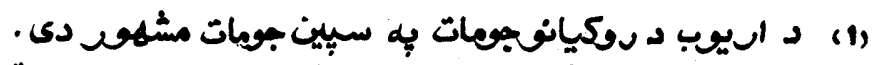

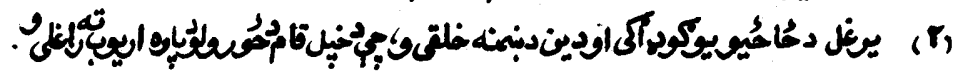


J ل

YA

سينبs

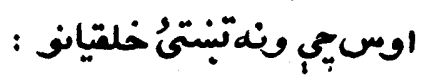

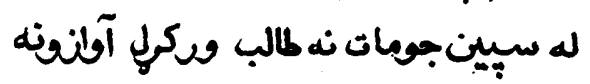

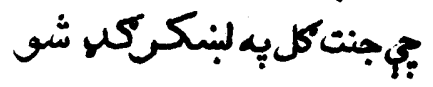

خلقيا نف جلك كل دل د تسـليم به دود لاسونه

لحمن دحق له لاري جار كي

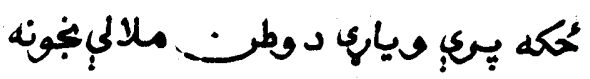

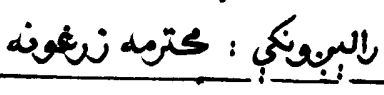

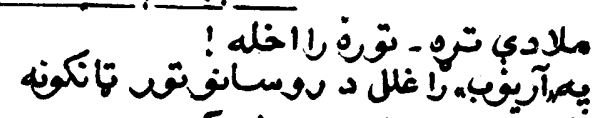

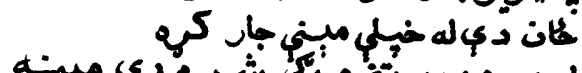

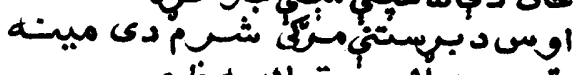

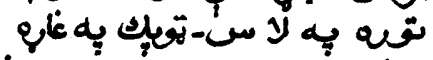

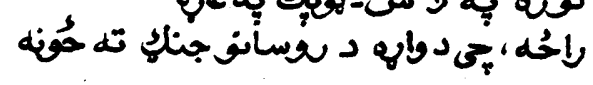

جنت دمغوخلكوفماى دى دي

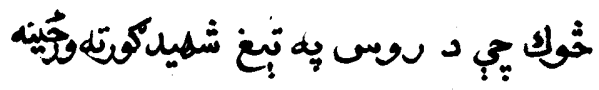

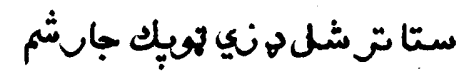

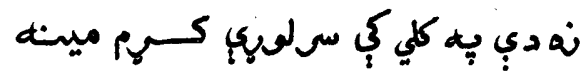

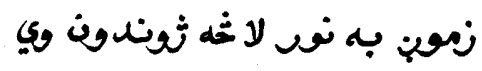

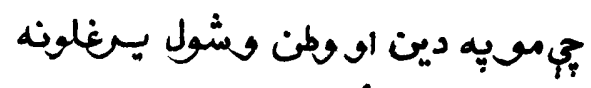

كامله ! خدائ كه، بنادي وكئي

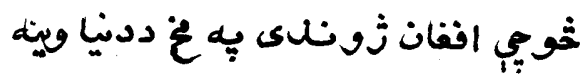

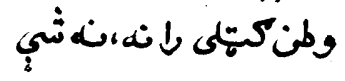

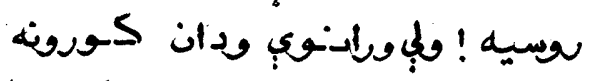

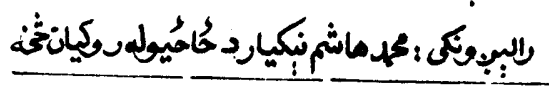




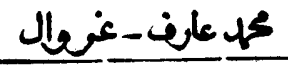

\section{ل اســونه وخل}

جا بي كونغرب-بوري يتيمان راسمع وزيل؛

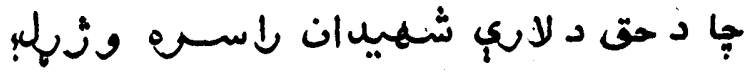

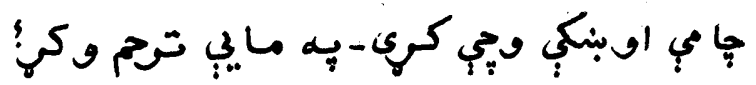

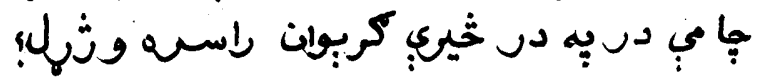

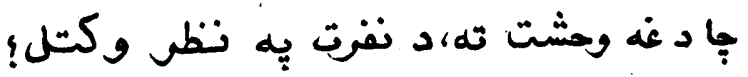

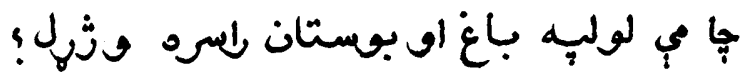

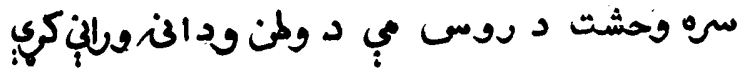

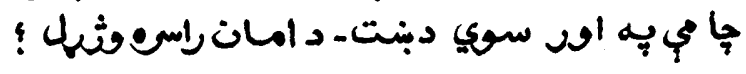




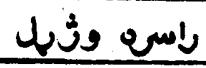

$7 V$

سيبدي

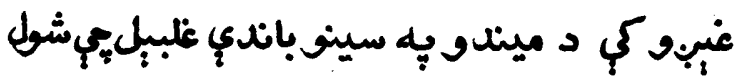

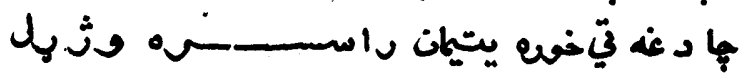

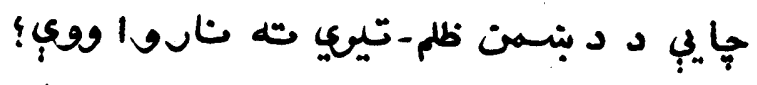

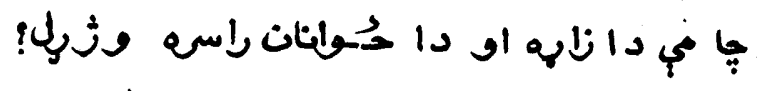

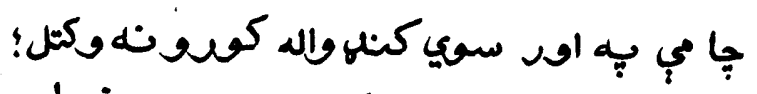

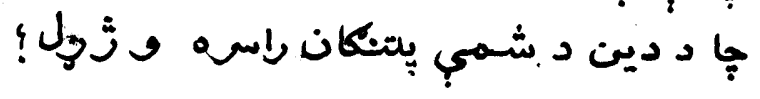

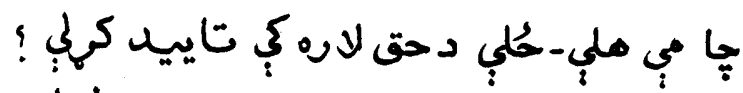

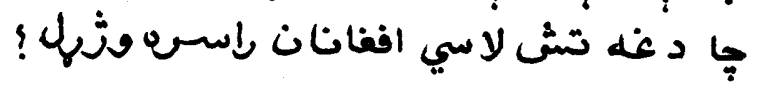

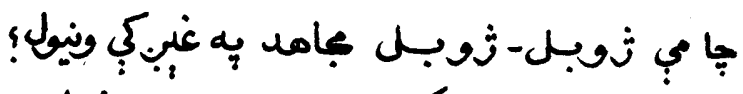

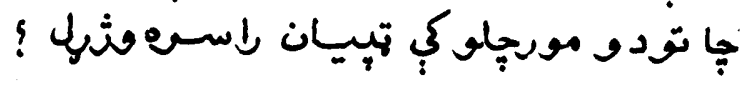

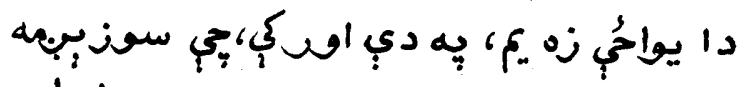

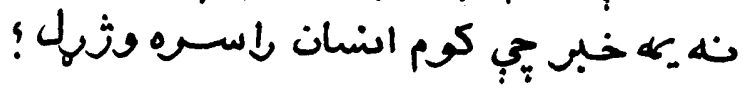

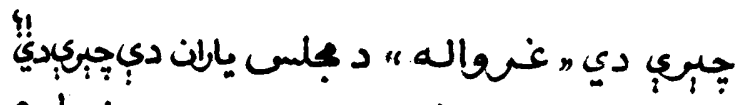

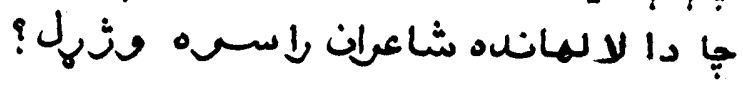


كتره زكيه

راسـص وزّل

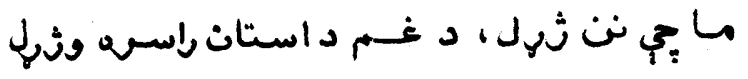

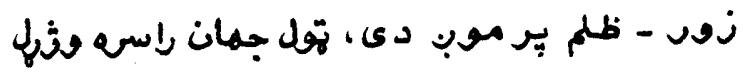

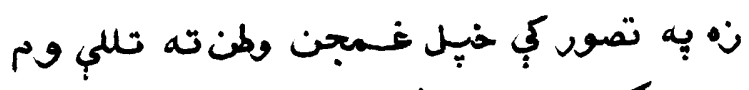

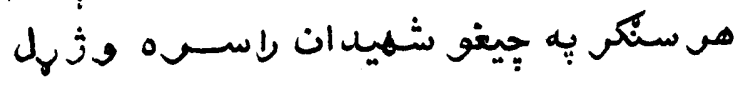

خيال كب مب د كملان افغاسنتان،يج آنادي راغله

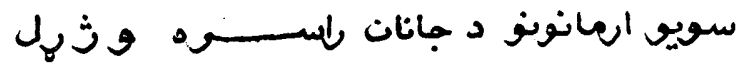

شـهمي، يجي مب بلي د شهـيد به مناد وليدي

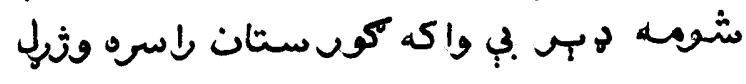


fitor-w

79

سيبدي

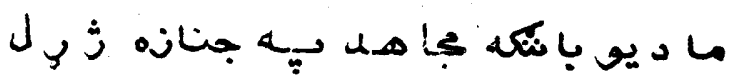

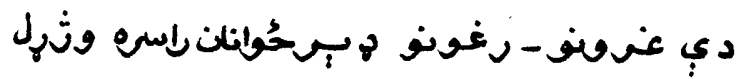

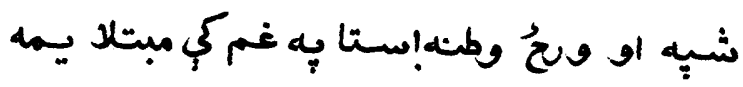

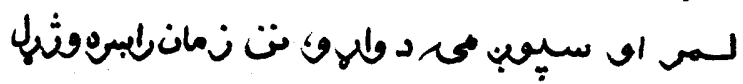

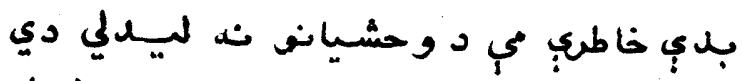

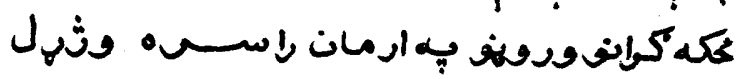

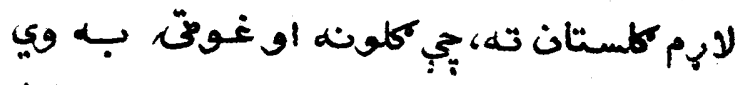

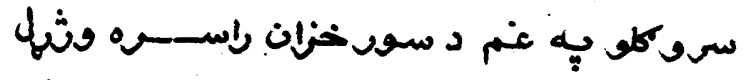

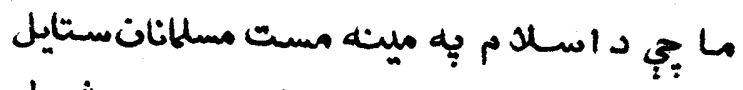

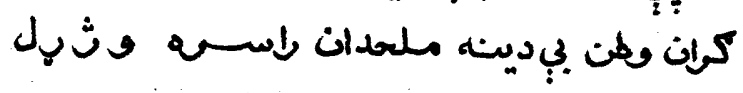

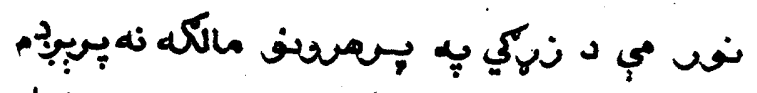

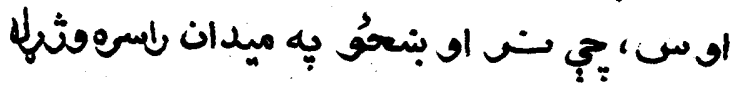


نبكيال

\section{لاسـه وثهل}

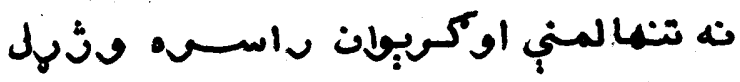

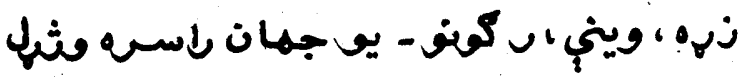

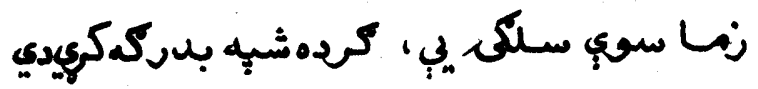

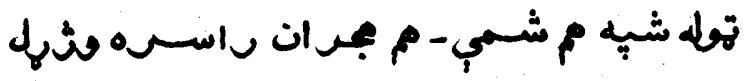

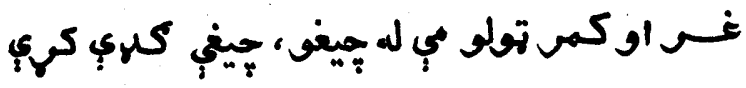

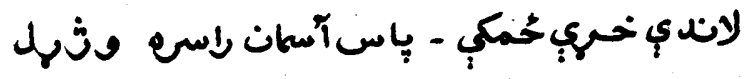

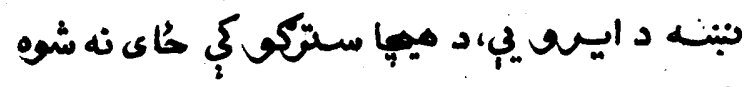

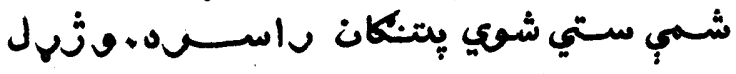

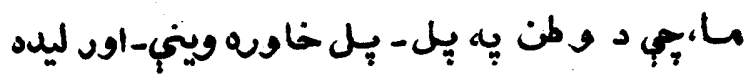

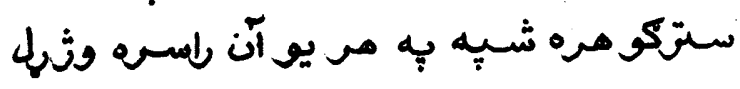

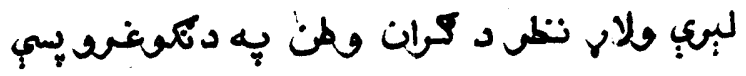

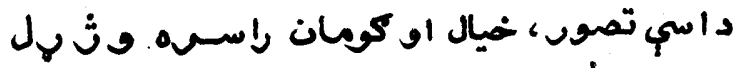




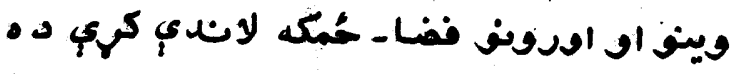

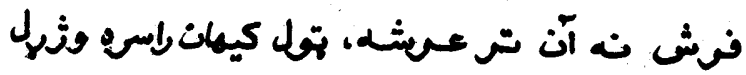

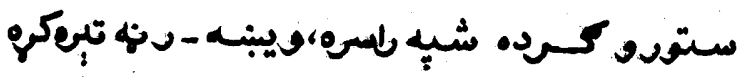

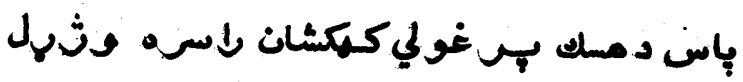

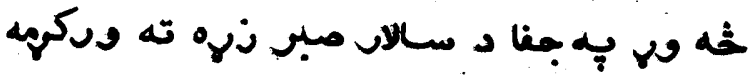

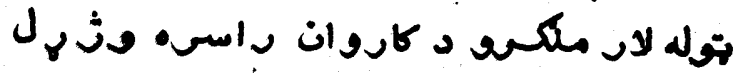

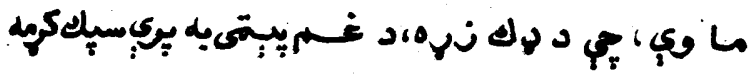

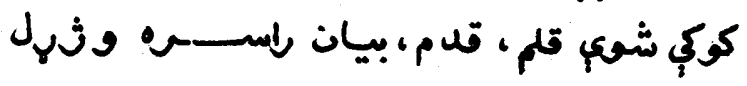

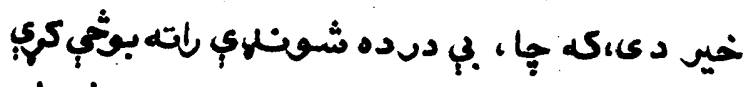

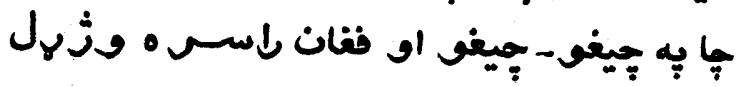

دا يج مي زخمونف به خند ا خولد خلامه كريجه

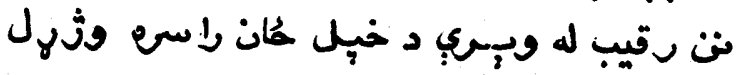

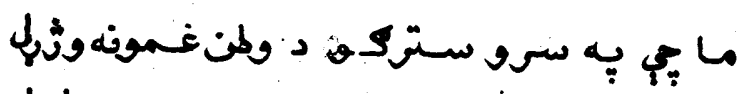

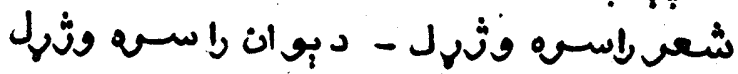


سيدمئدين-رهغيق

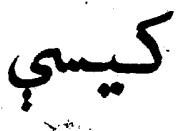

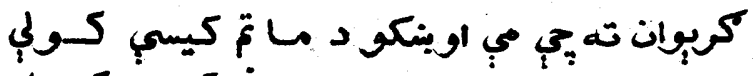

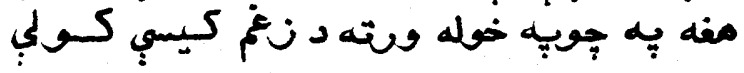

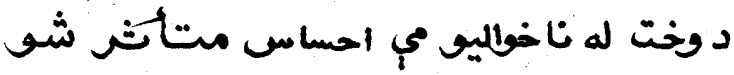

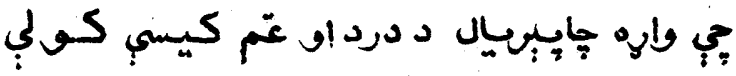

د فكسو خيال مسرغه مي د هباد به لوي والوت

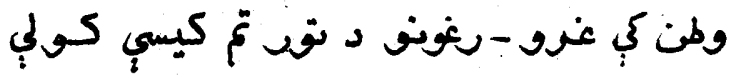

درونه وو، رئورنه وو، اورونه وو - ويـونه

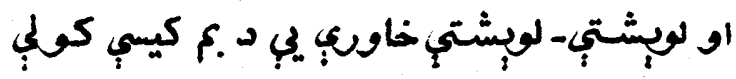

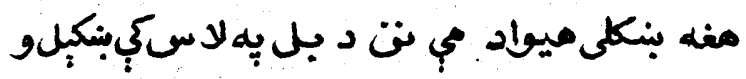

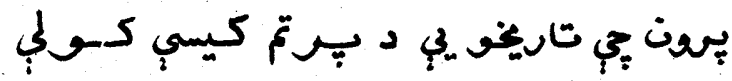

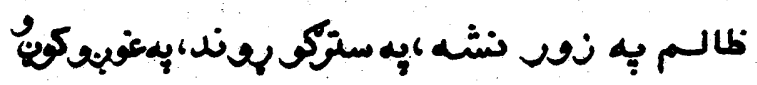

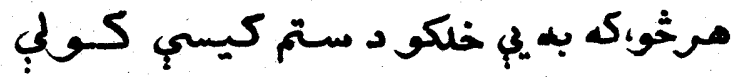




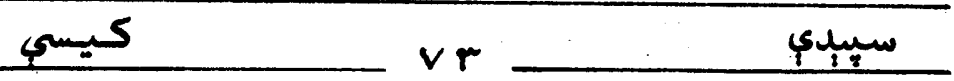

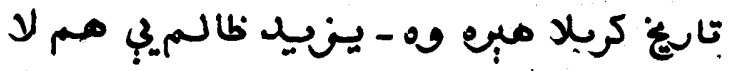

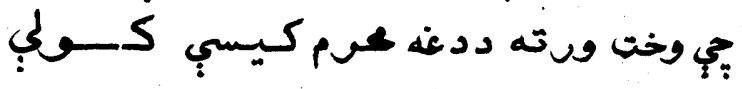

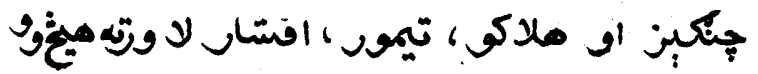

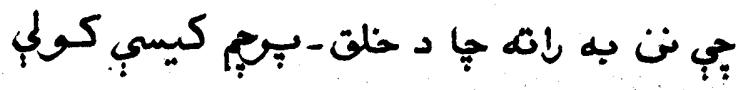

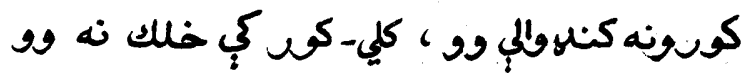

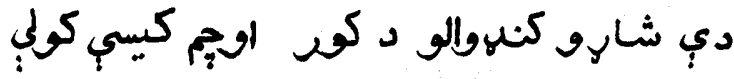

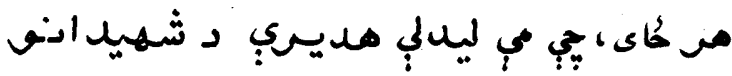

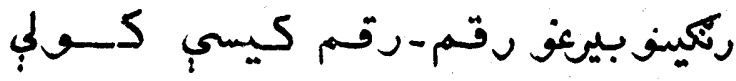

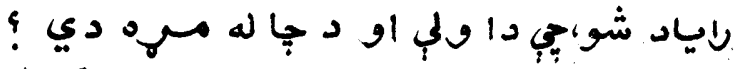

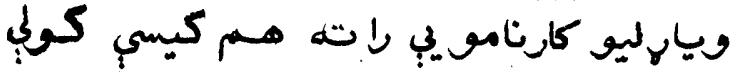

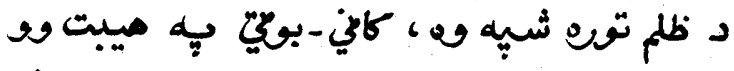

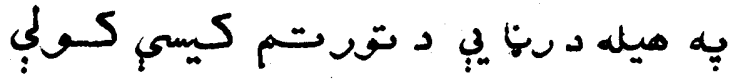

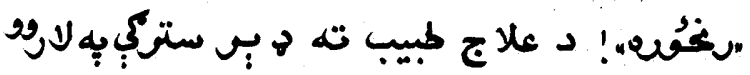

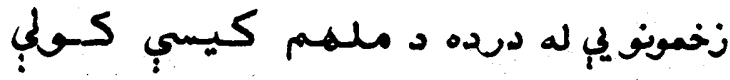




\section{اماناقلهـنصرت}

\section{افغانسفيُ}

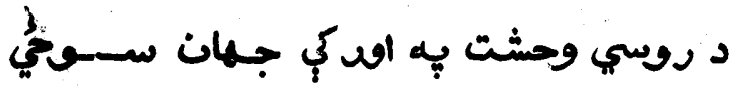

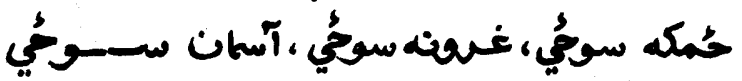

هرجمن باندي مسكروجيّ لاوريــيّي

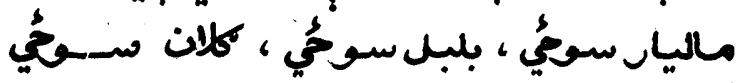

سـردرو نه شَنب لوخيّي بورته كيبي

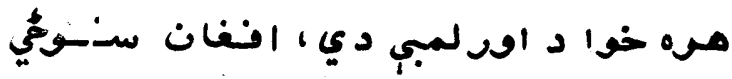

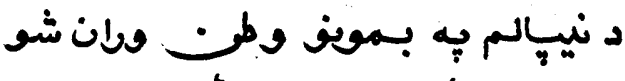

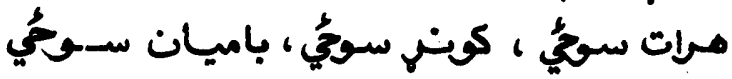




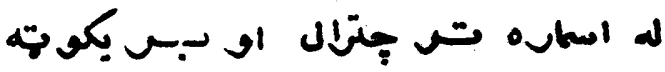

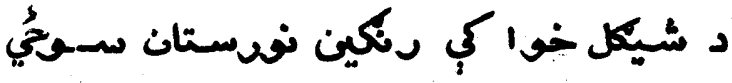

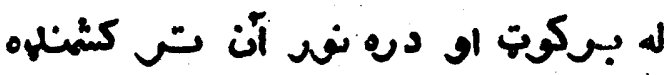

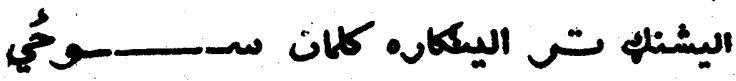

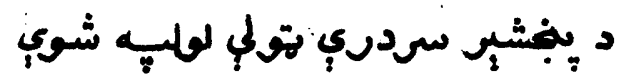

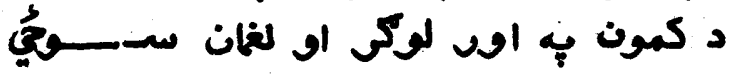

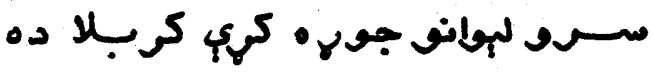

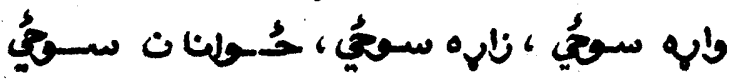

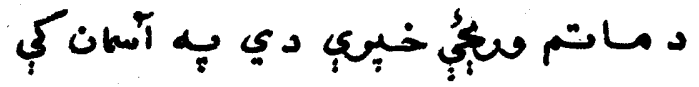

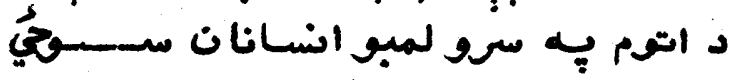

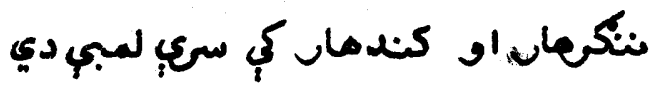

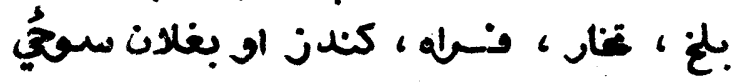

يه كابل د سمو اورونو بالن معر دى

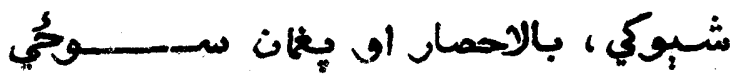




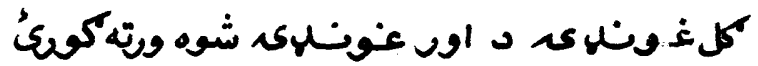

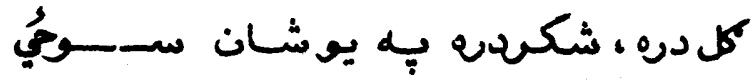

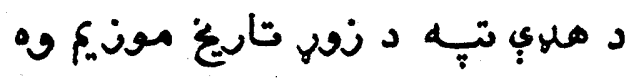

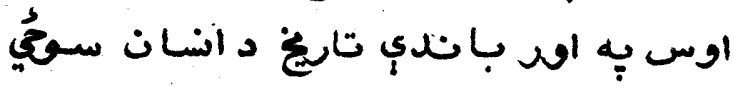

$$
\text { استالف باندي اورونه كيدي }
$$

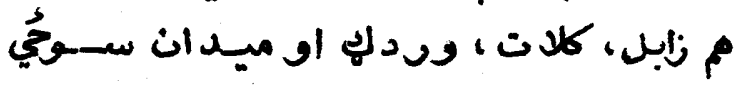

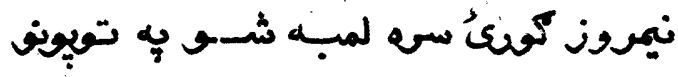

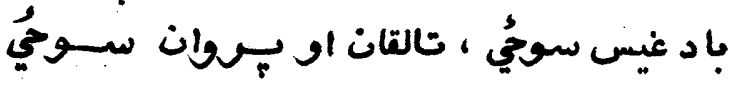

يكتيا بِه روسي اون بانفي ستي شقح

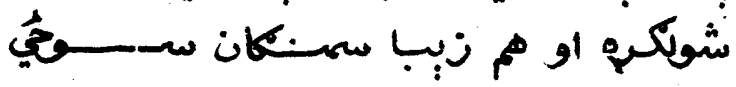

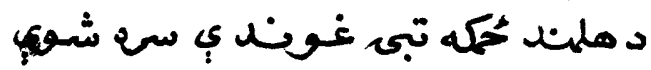

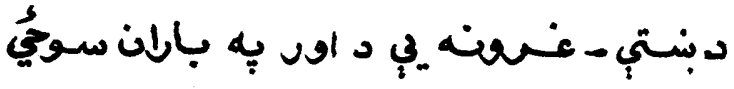

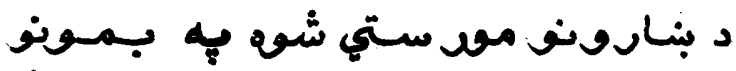

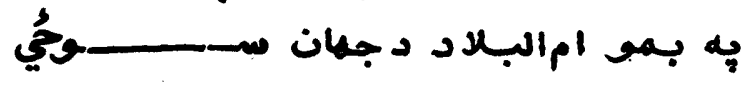




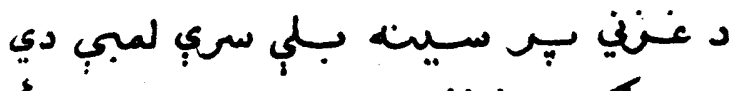

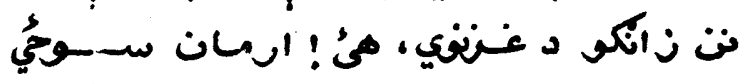

د نابع كلانه خاورو كي جبراته دي

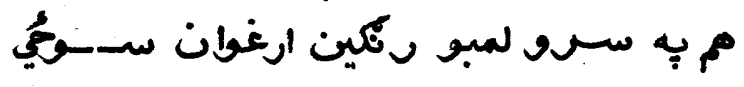

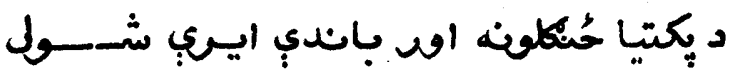

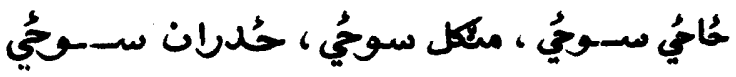

ماهيبيكي د سرو وينو فواري دي

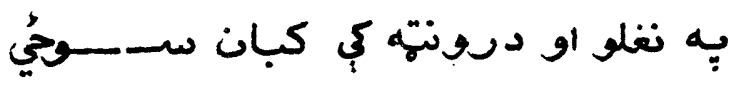

$$
\text { دمببواد شتمني لوتّ كيله روسـانو }
$$

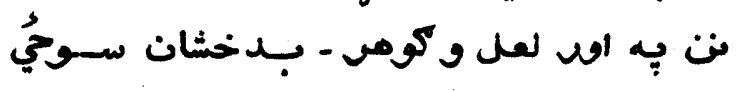

اى • نمرته !، هرخو ا اور دى او ويرونه

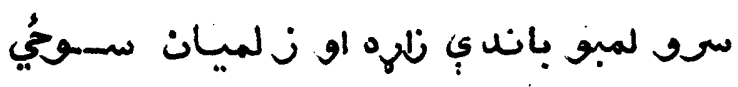

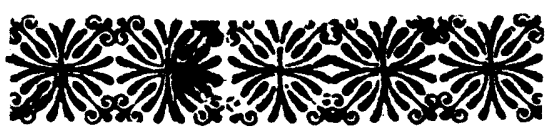




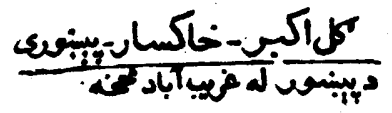

$$
\text { ایىمسله خد ائد ياره ...” }
$$

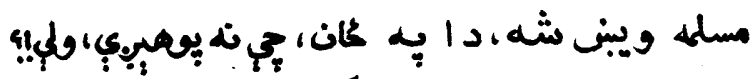

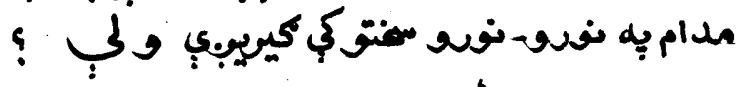

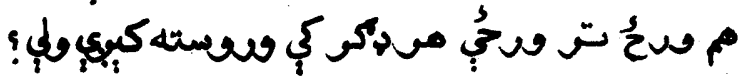

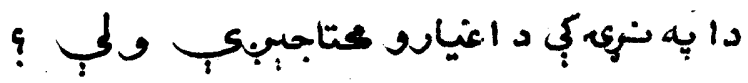

اول خص، داسي نه وي ، تا حكو متوقنه كول

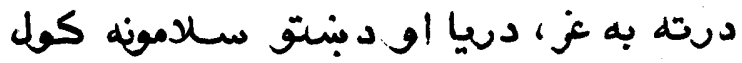

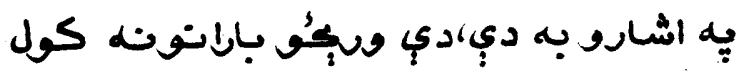

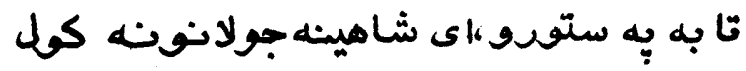

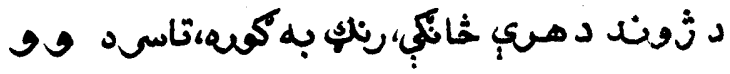

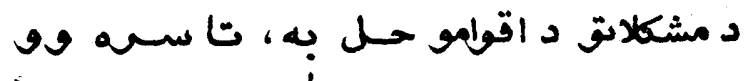

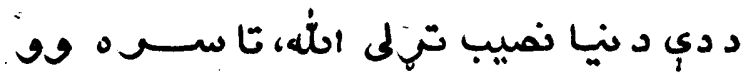

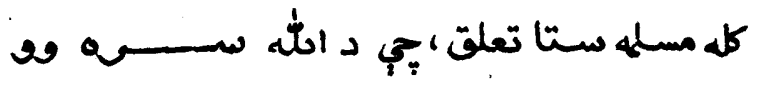

لبِ حان واقف كيه ، خيل تاريخ د مشنانوحُني

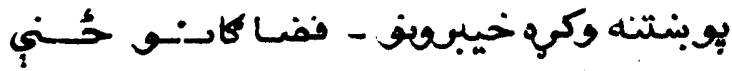

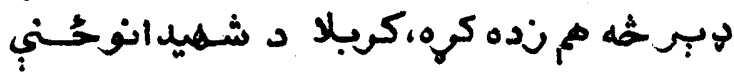

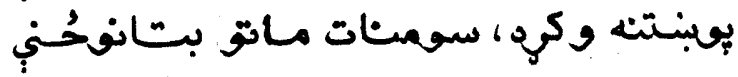




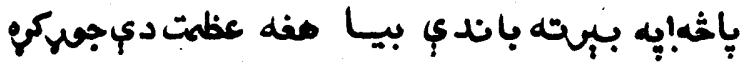

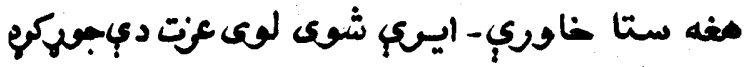

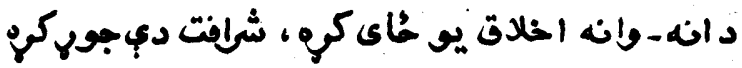

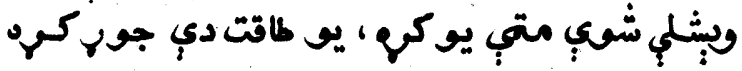

\section{$\Longrightarrow$}

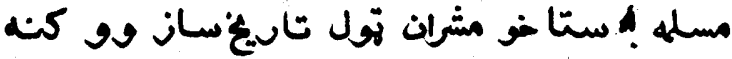
هنفى سىتيتي نه وص ، هر دم سرفلا ص كنه

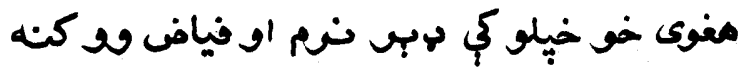

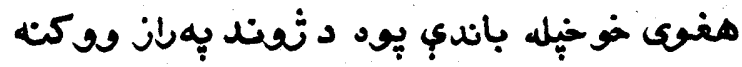

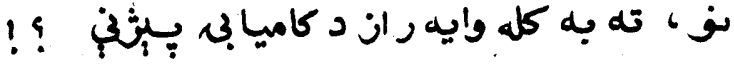

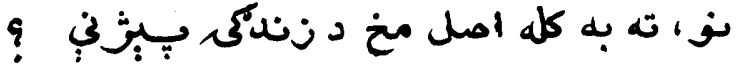

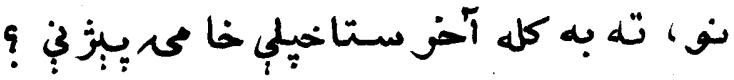

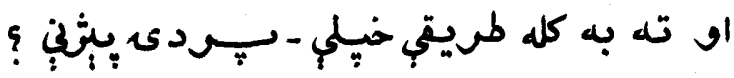

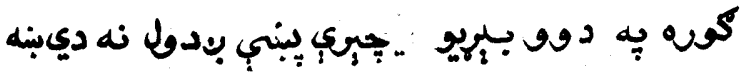

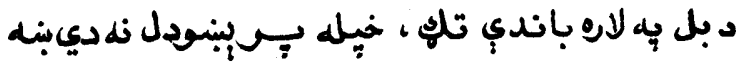

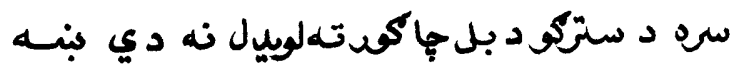

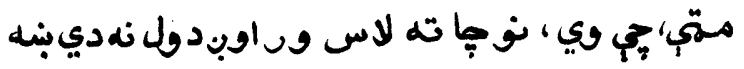

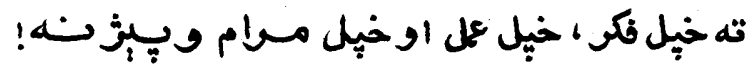

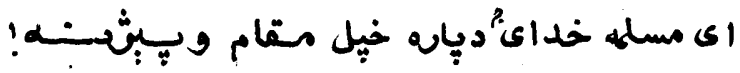




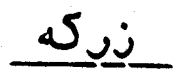

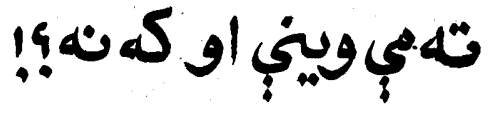

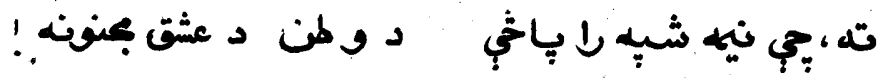

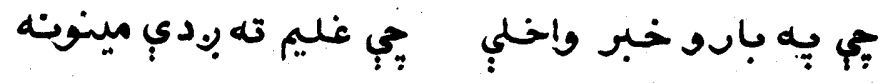

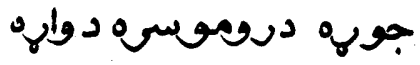

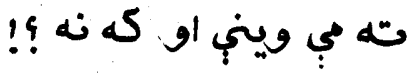

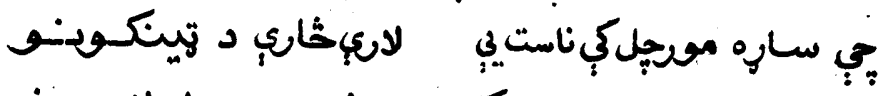

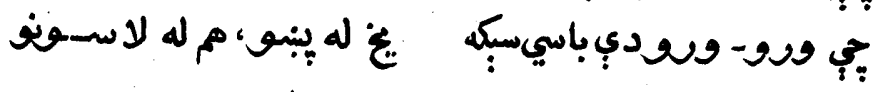

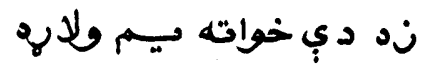

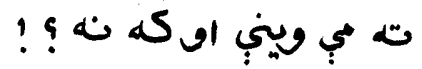

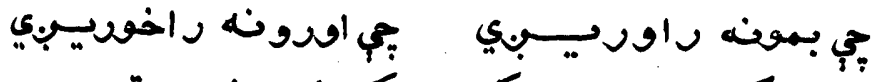

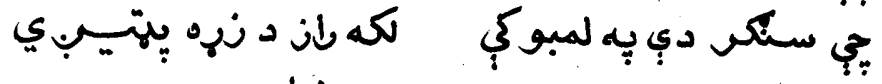

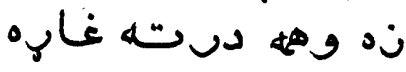

ته مي ويني اوكه ده نه 


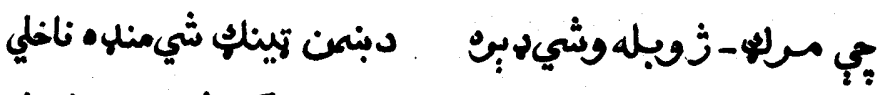

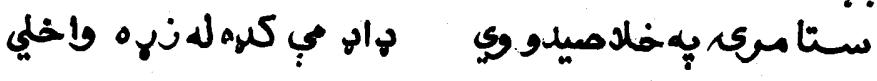

$$
\begin{aligned}
& \text { قيوي مي خطله }
\end{aligned}
$$

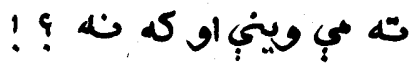

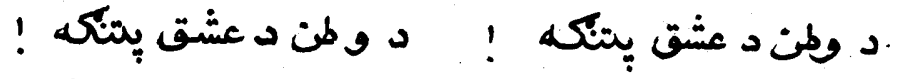

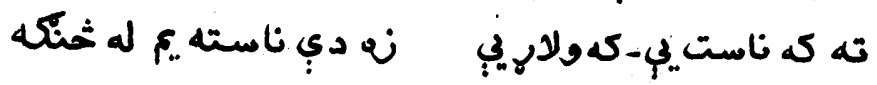

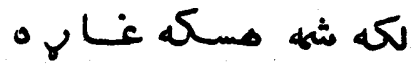$$
\text { ته مي ويتي او كله نه ؟ }
$$

$$
\text { : }
$$

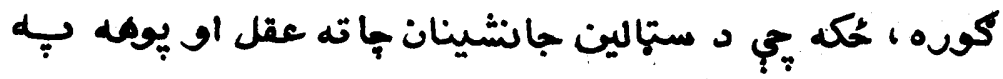

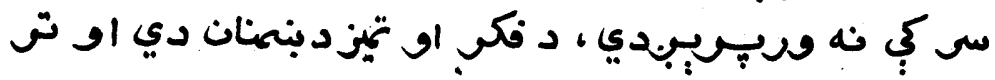

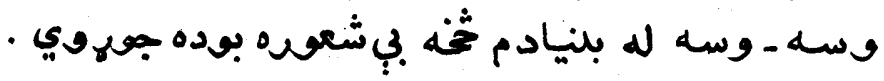

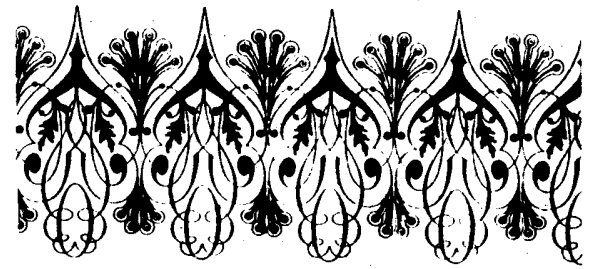


انْوِركم

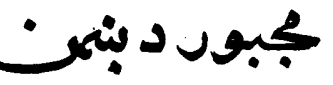

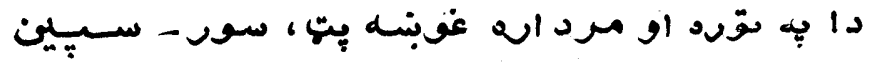

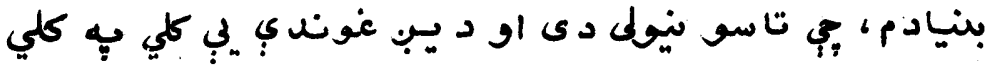

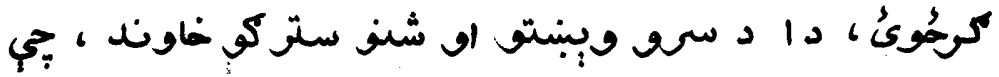

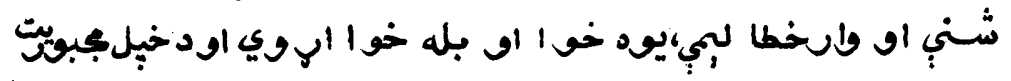

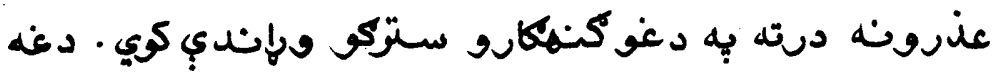

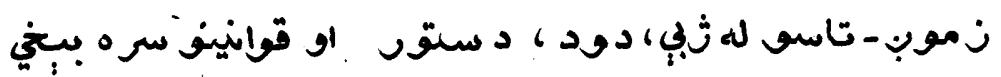

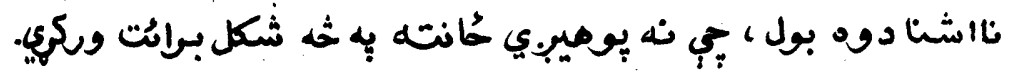

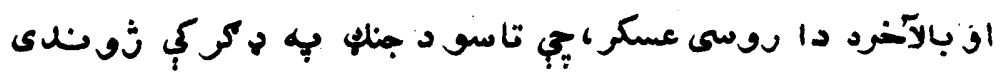

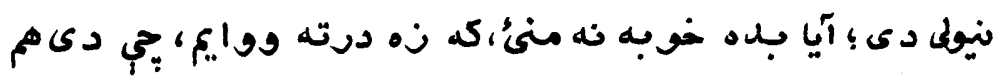

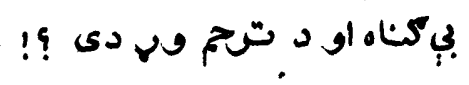

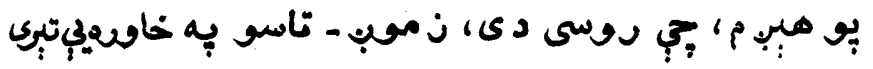

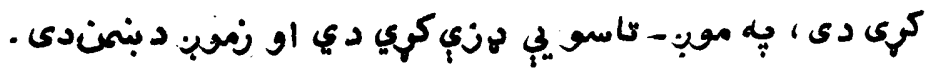

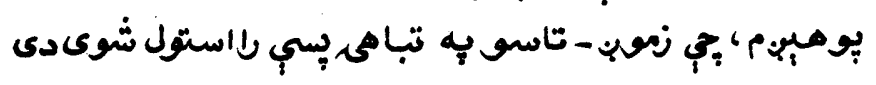




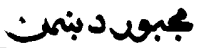

Ar

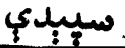

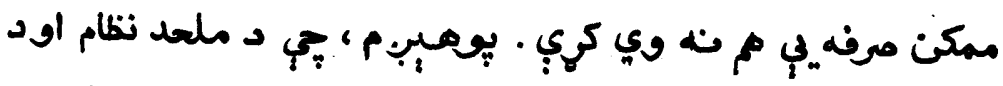

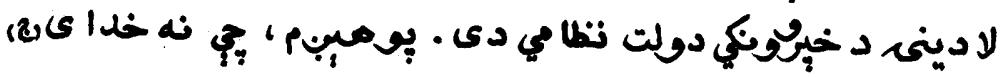

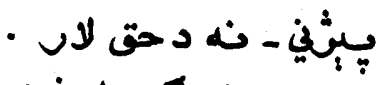

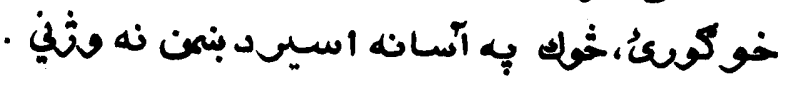

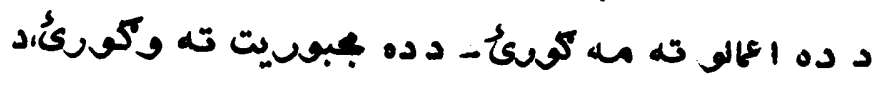

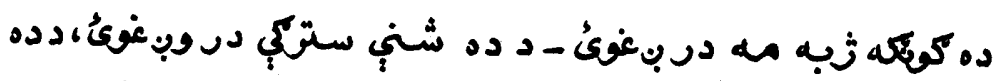

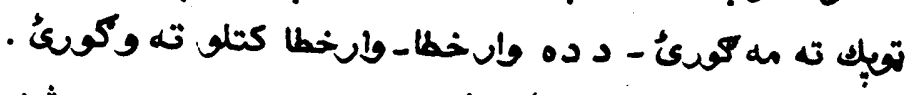

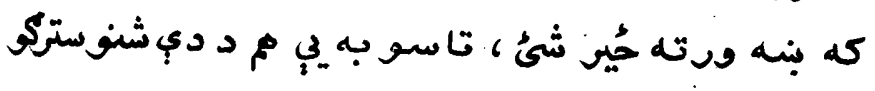

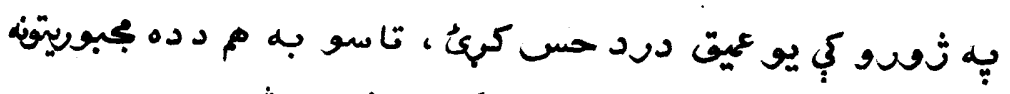

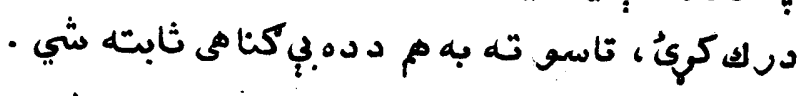

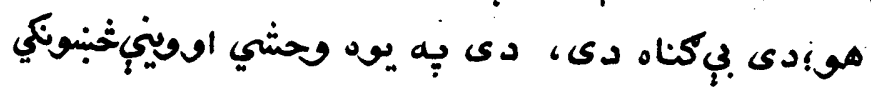

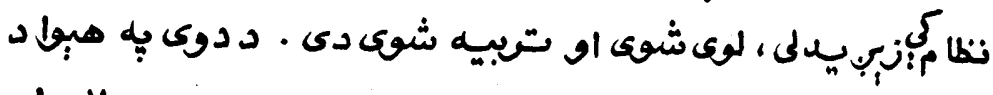

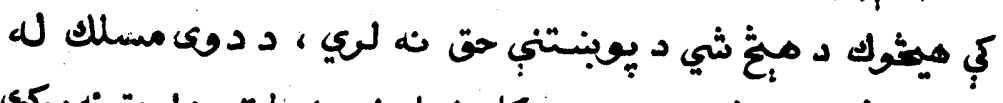

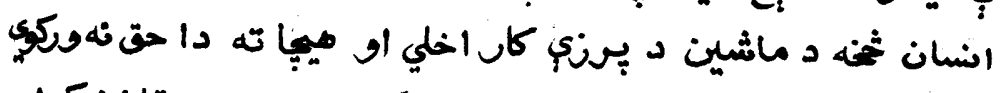

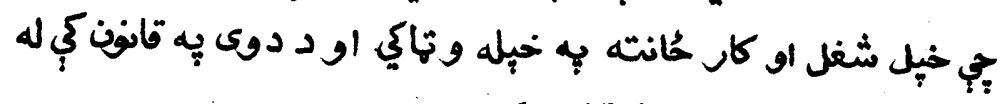

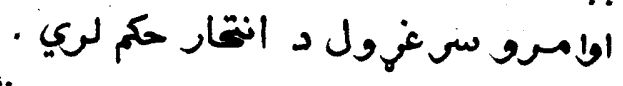

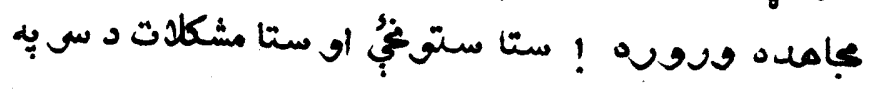

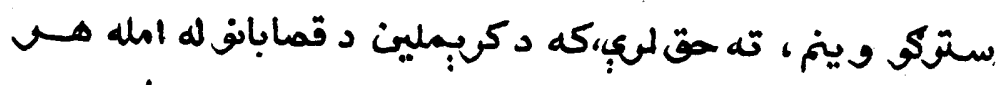

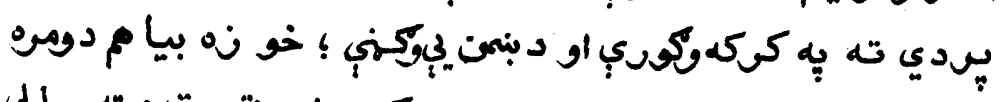

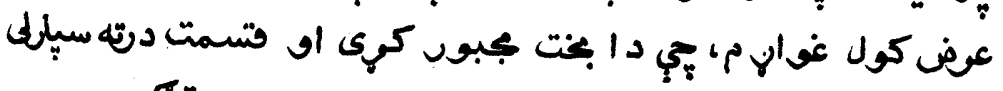

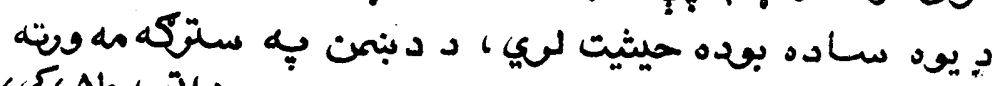
( 


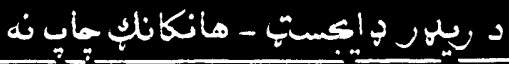

ثبانه : شيف-خليل

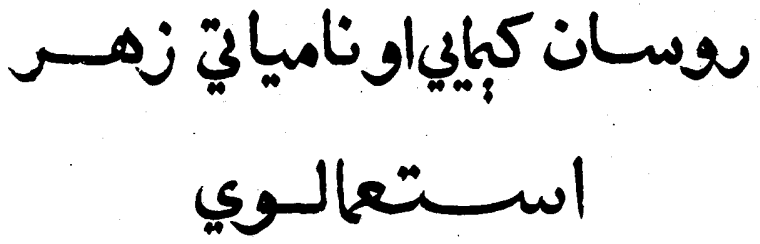

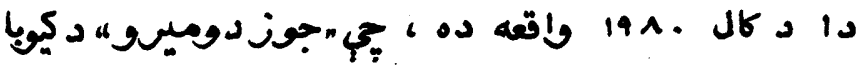

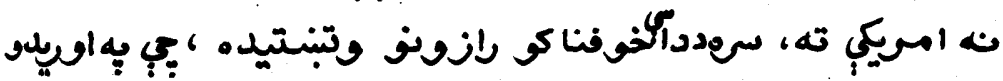

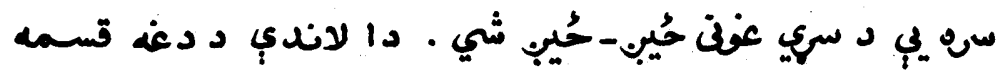

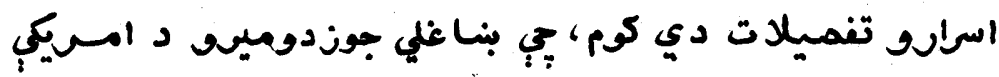

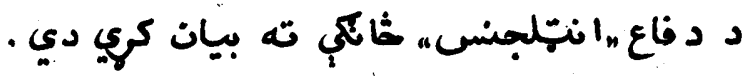

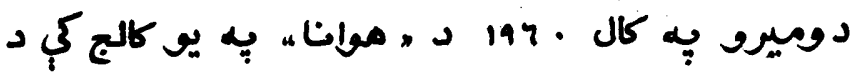

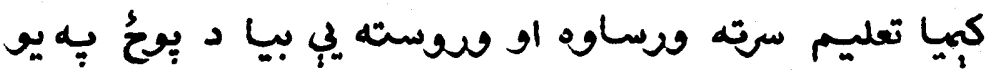

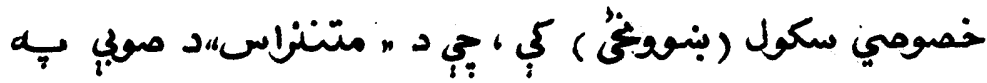

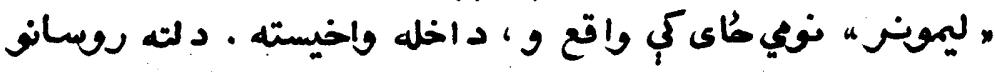

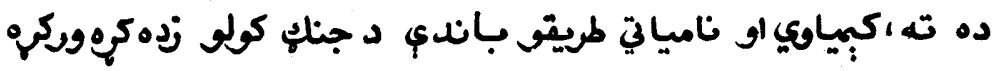

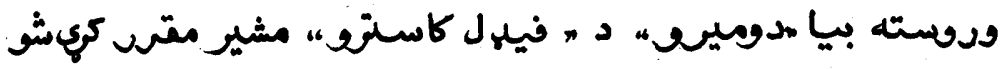




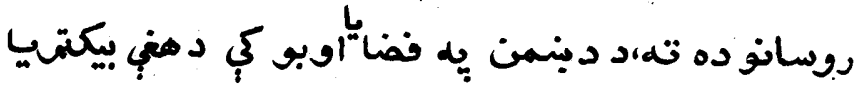

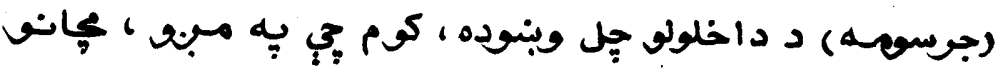

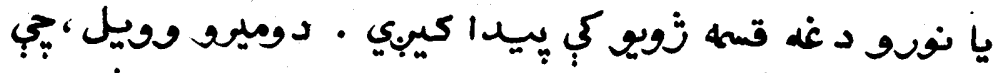

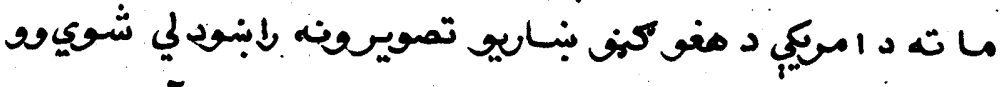

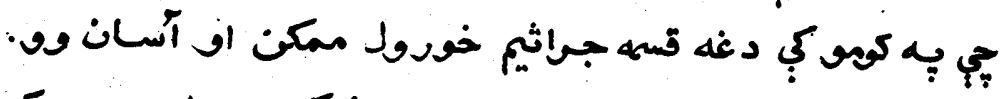

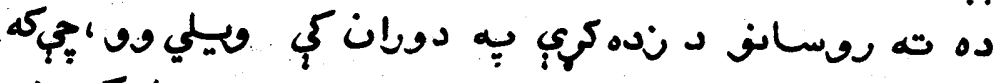

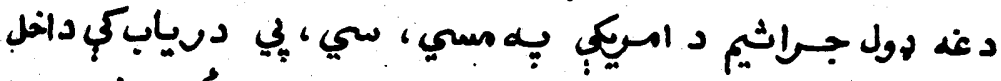

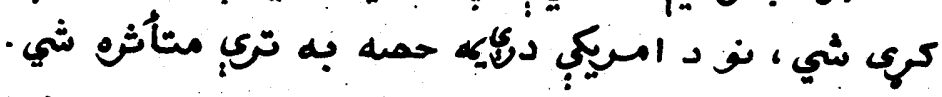

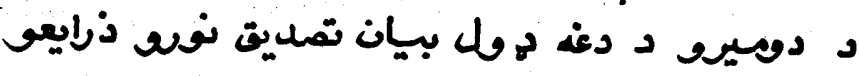

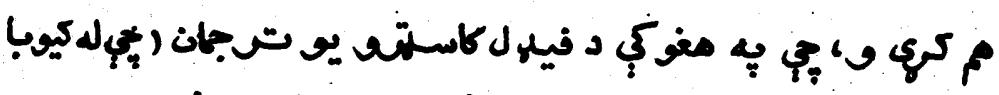

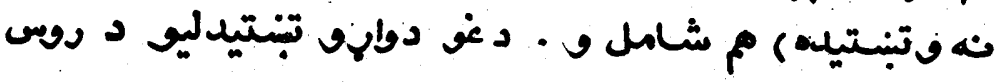

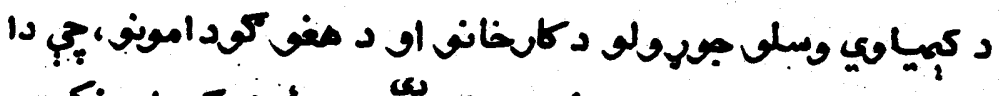

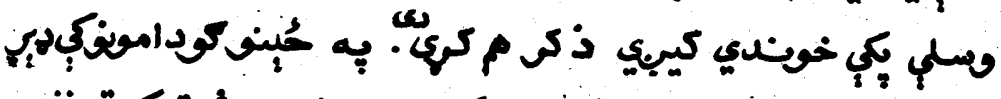

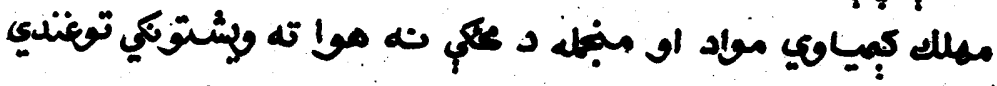

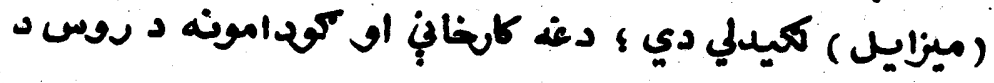

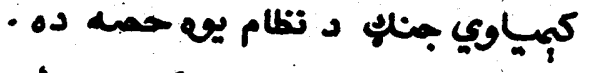

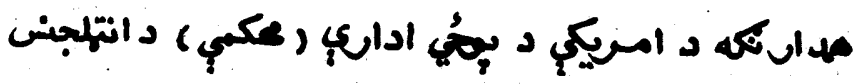

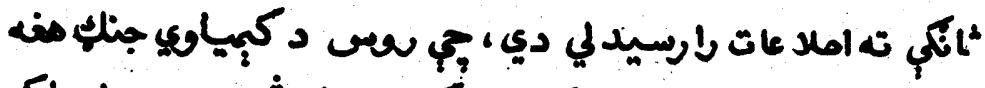

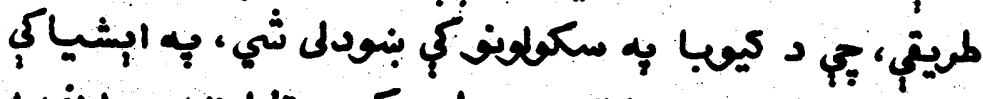

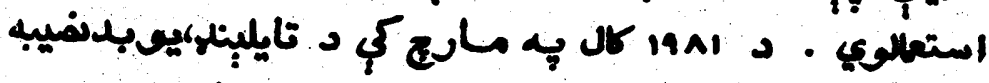

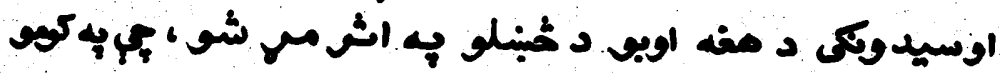




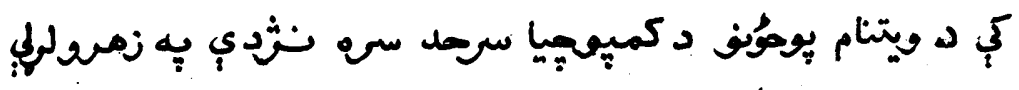

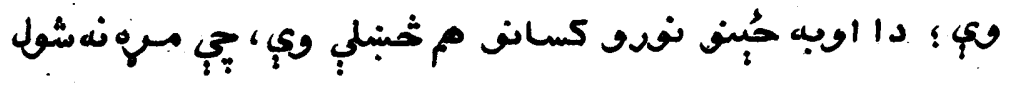

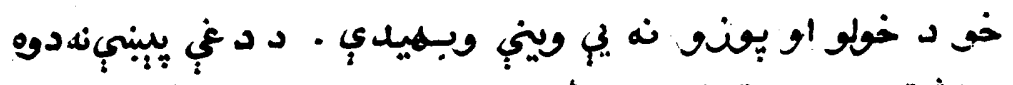

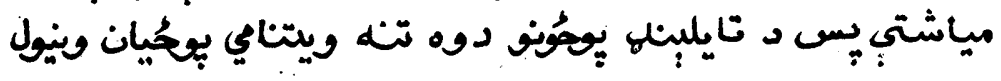

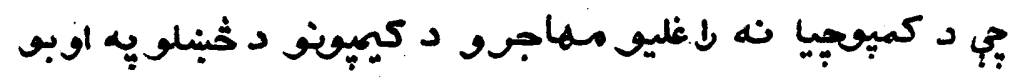

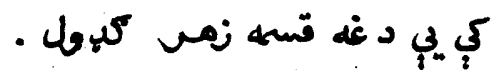

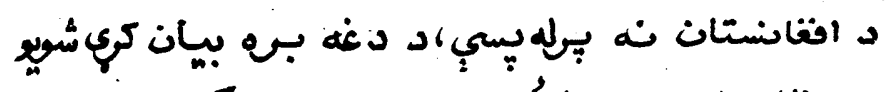

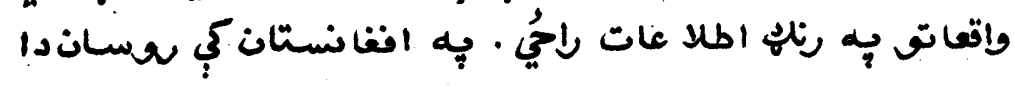

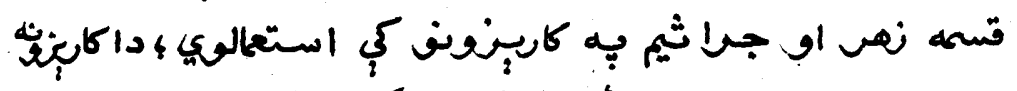

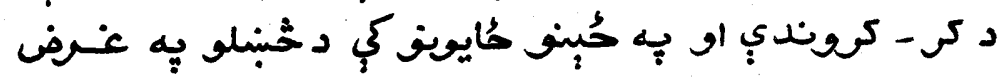

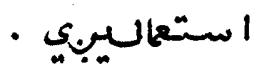

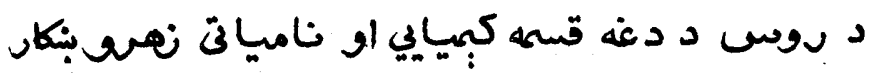

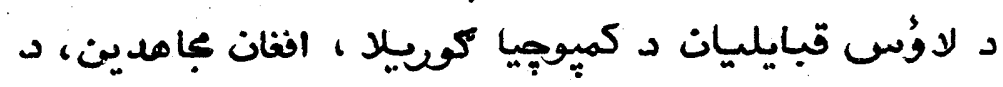

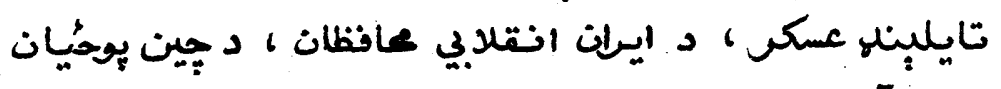

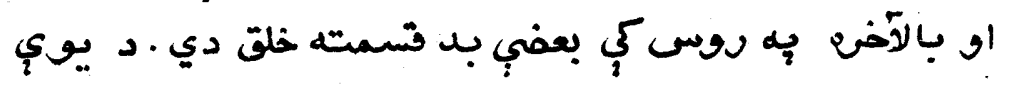

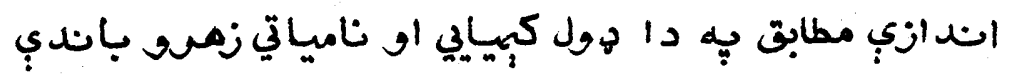

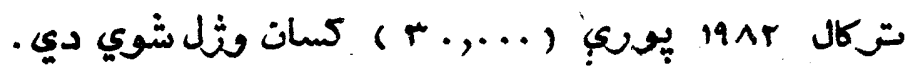

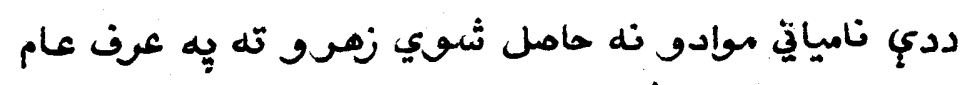

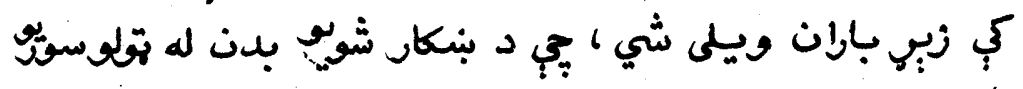

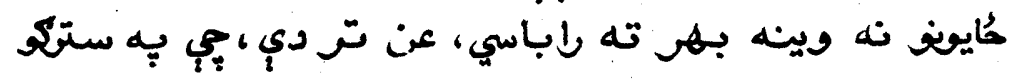

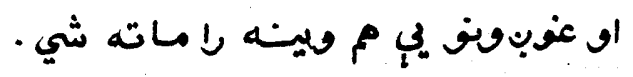


د اعمابو ديانه د روسانوكيـاوي كيسونه له فيلوبدنهبو

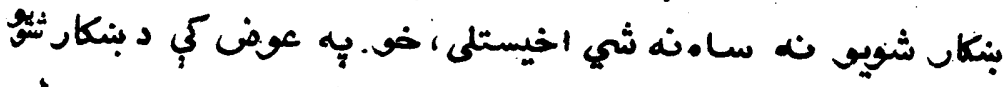

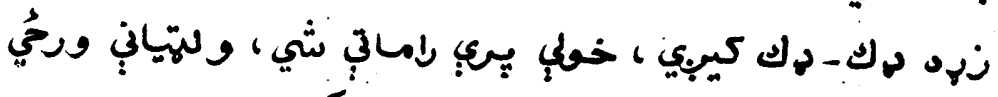

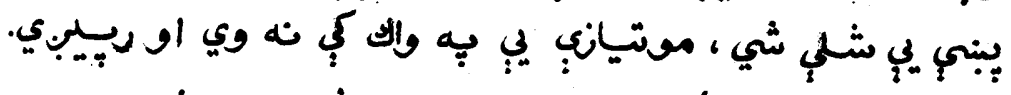

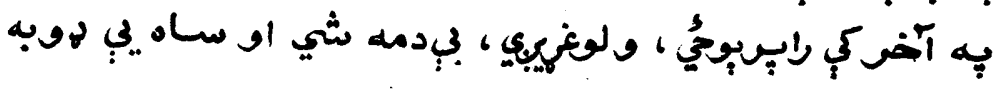

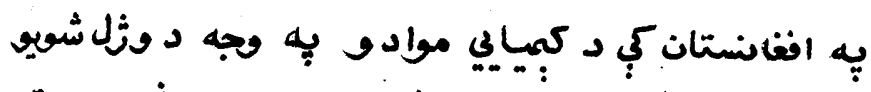
- ش

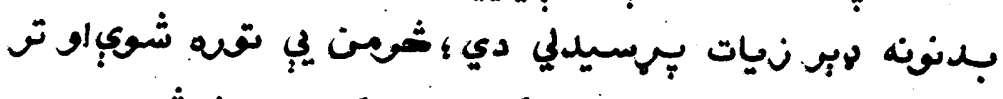

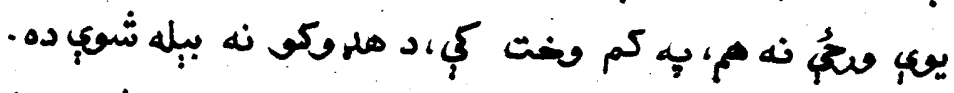

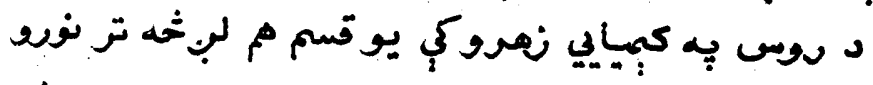

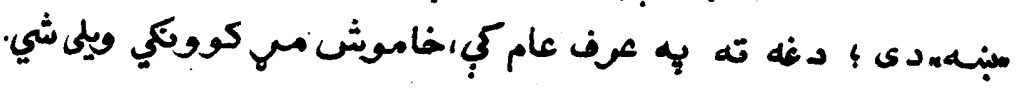

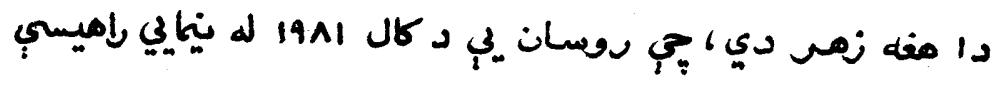

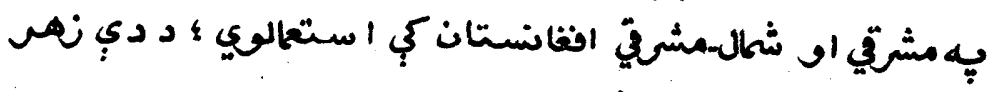

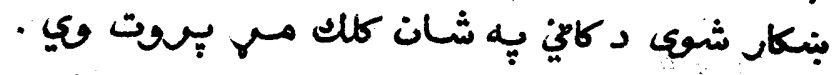

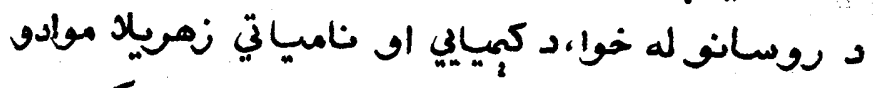

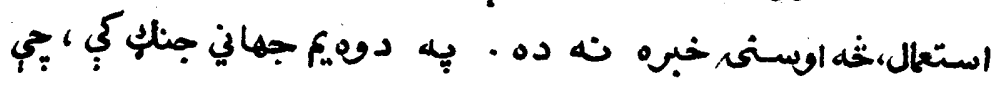

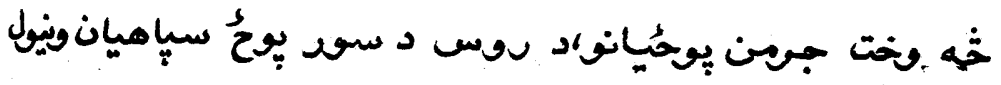

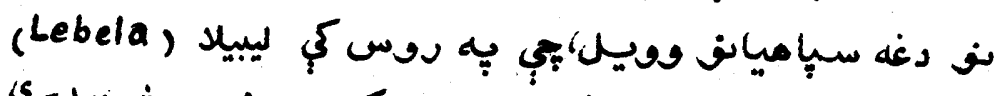

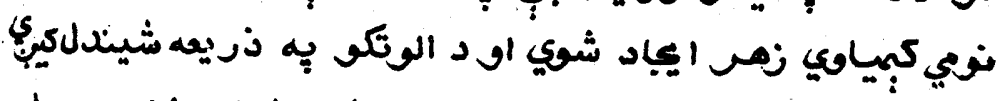

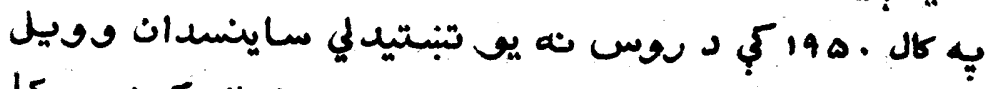

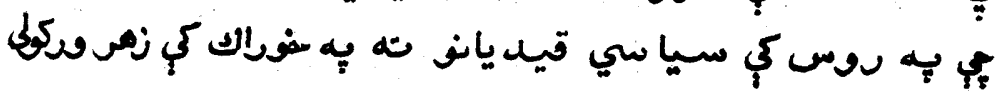




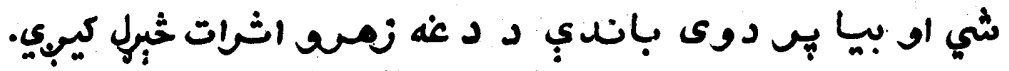

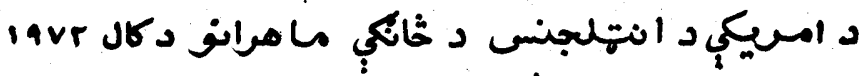

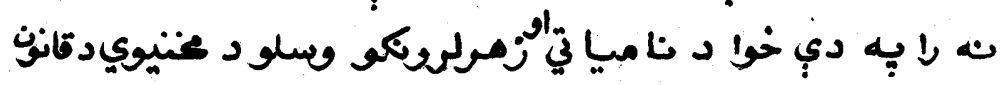

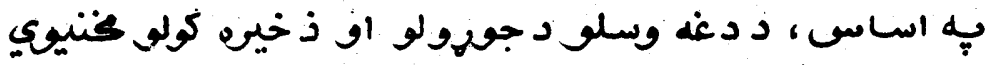

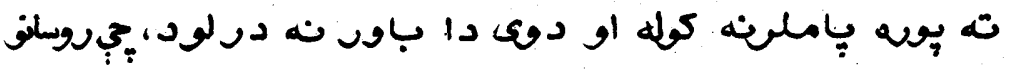

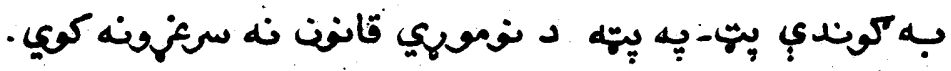

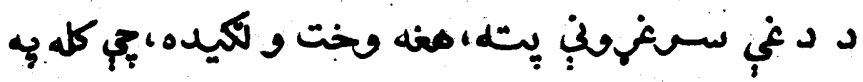

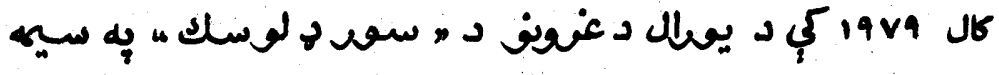

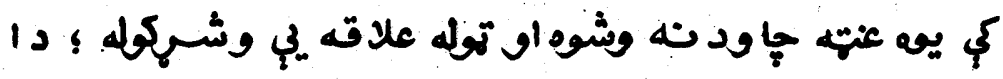

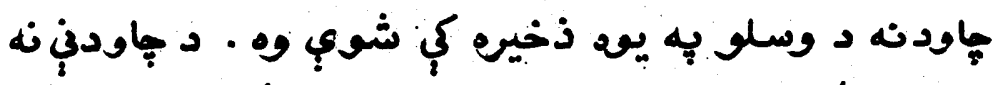

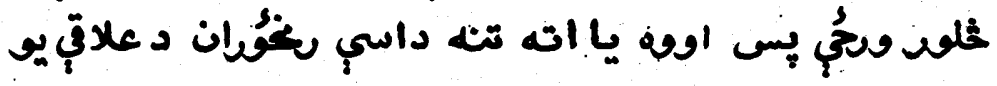

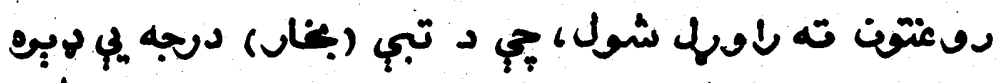

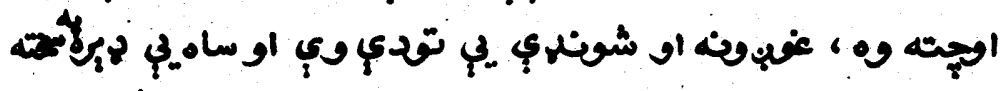

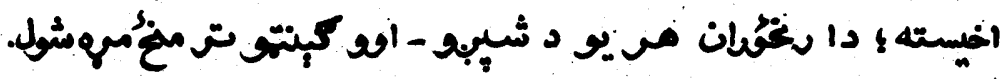

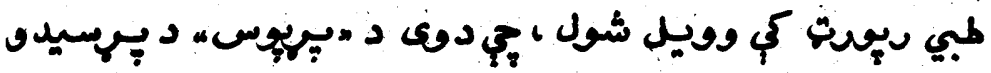

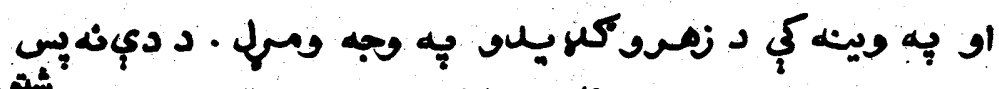

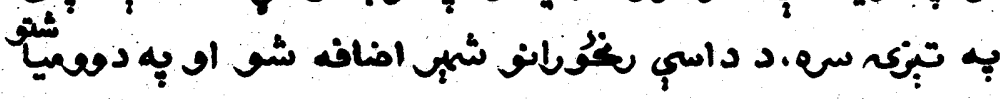

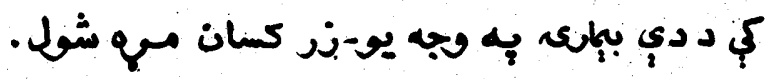

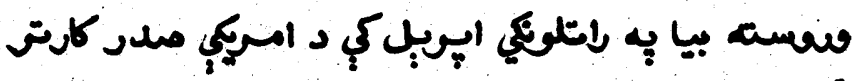

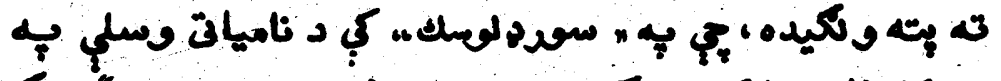

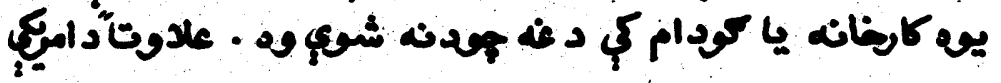




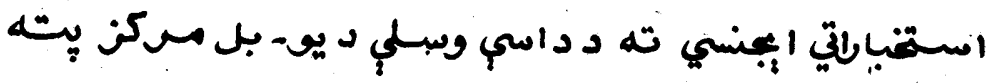

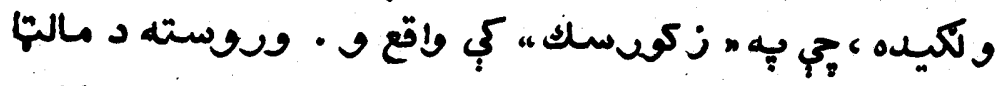

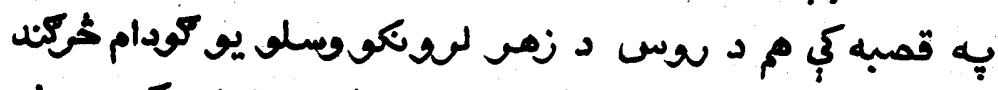

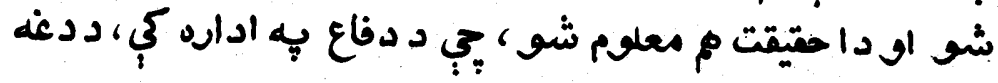

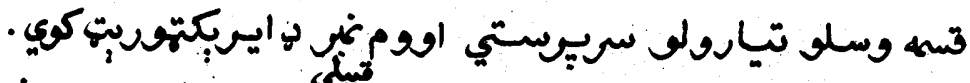

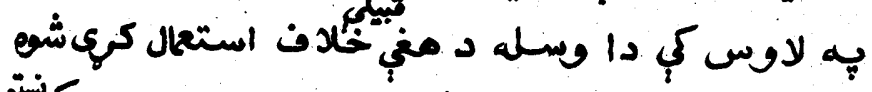

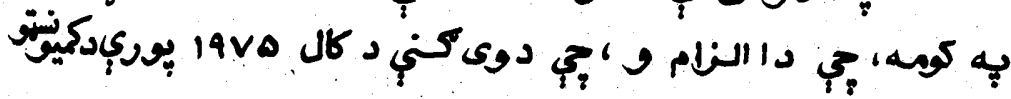

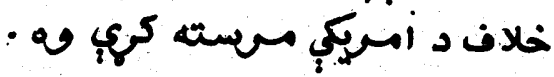

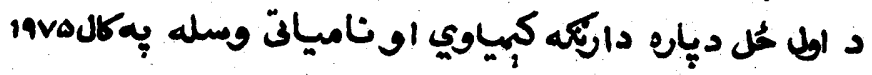

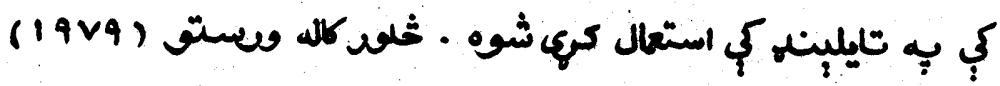

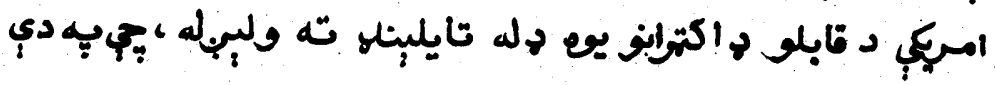

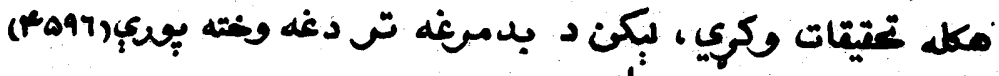

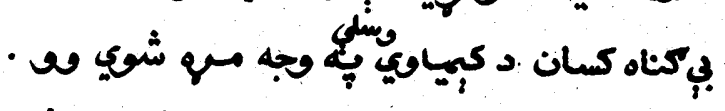

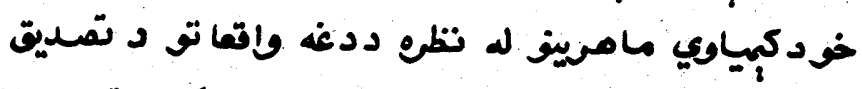

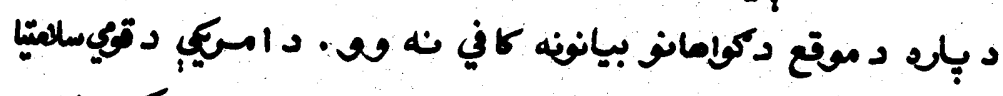

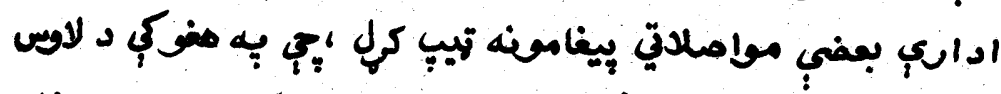

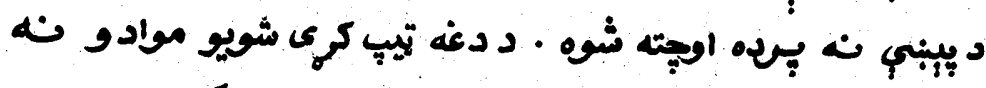

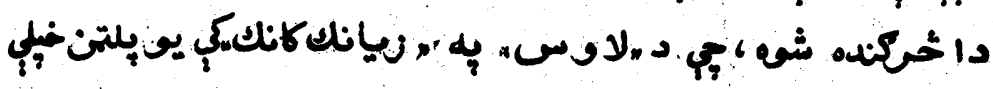

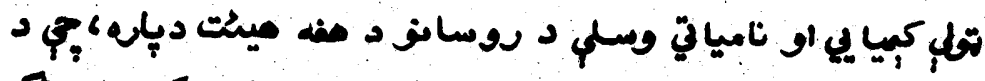

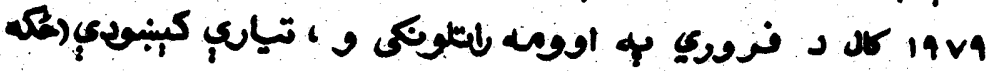

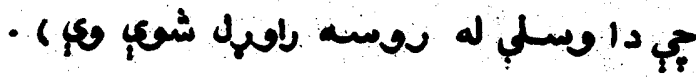


د يوبل موند نه دا يته وككيل ه ،ئي دكبيايِ وسلق

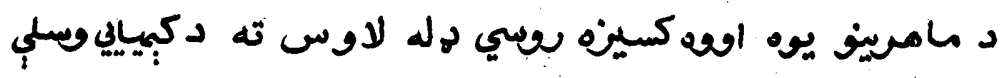

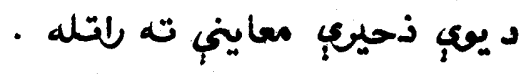

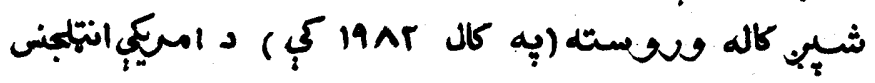

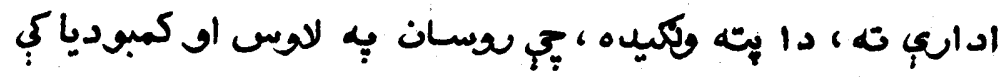

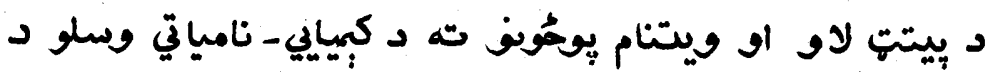

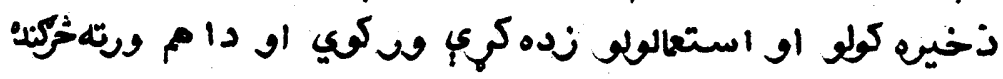

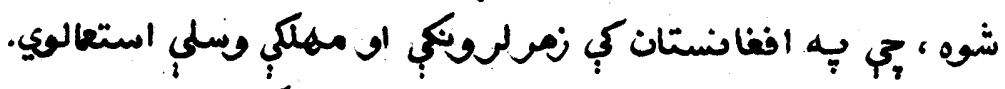

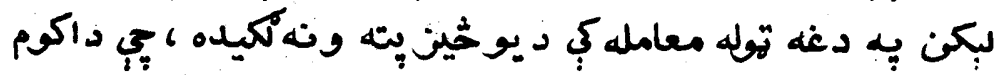

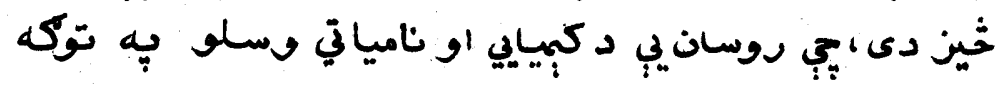
ا ستمعالوي

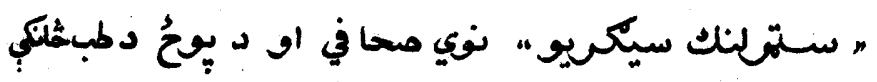

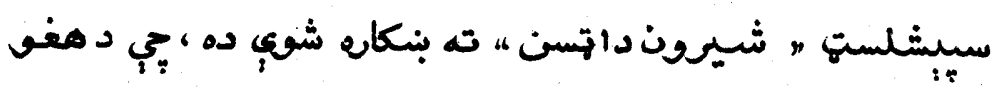

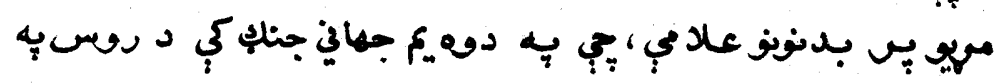

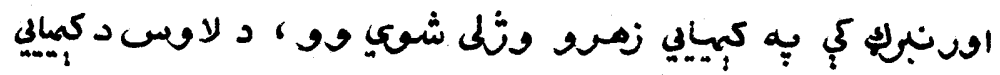

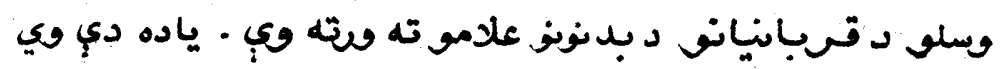

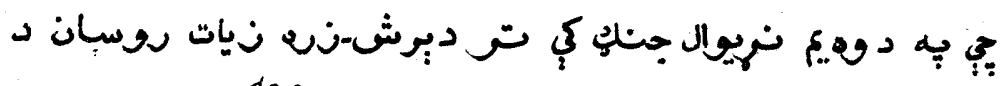

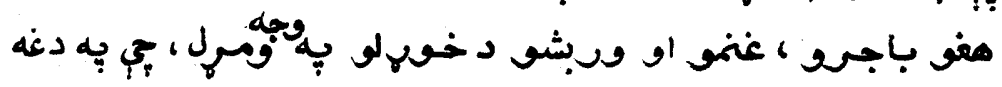

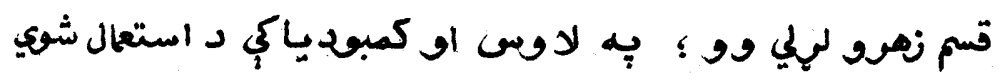

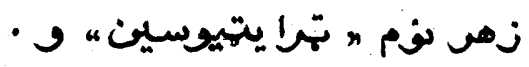

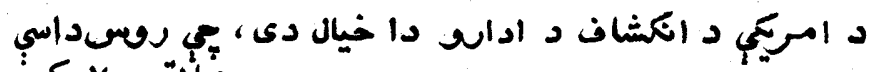

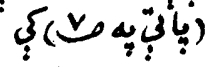


ب. P-

د اوبنـ يِبنـهـ

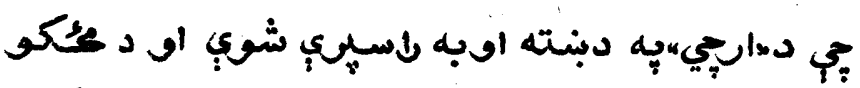

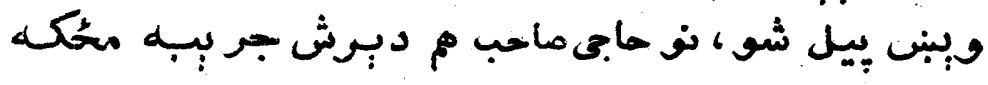

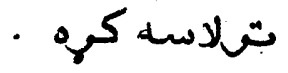

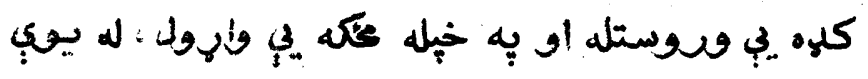

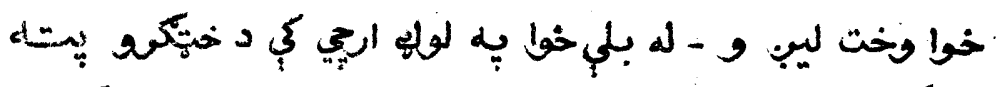

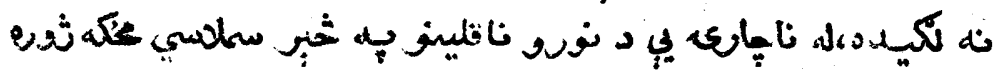

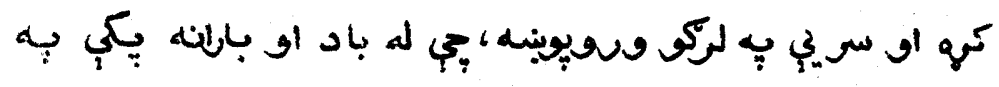

امن وي .

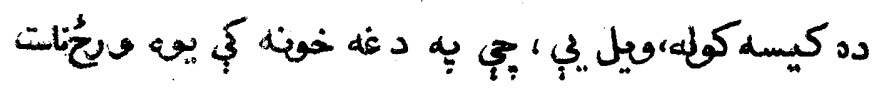

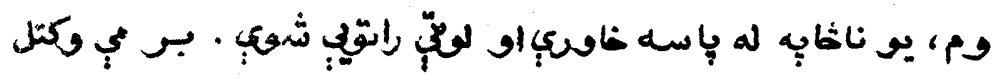

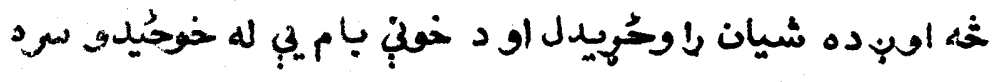

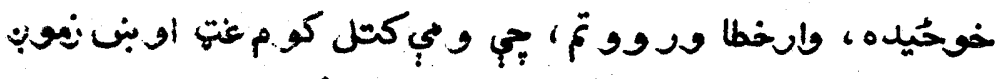

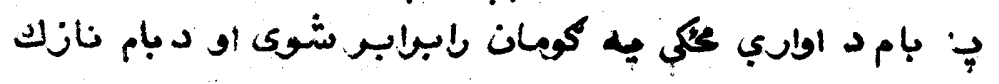




\section{د أوبن}

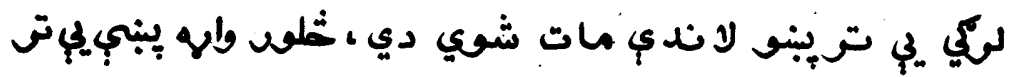

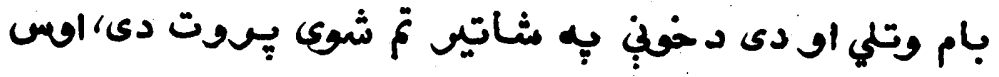

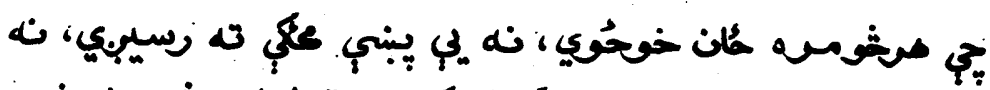

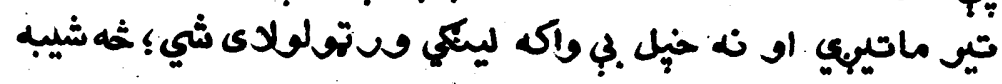

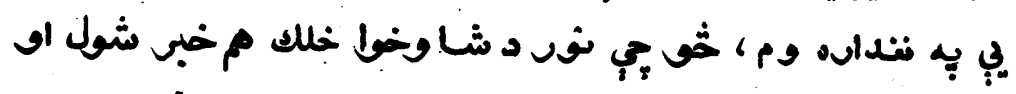

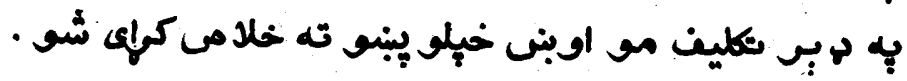

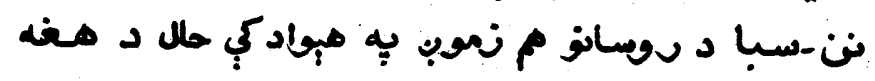

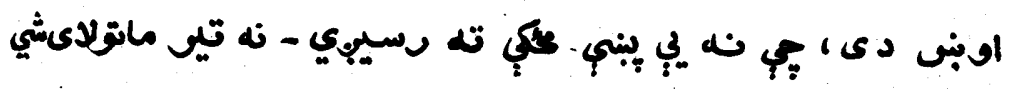

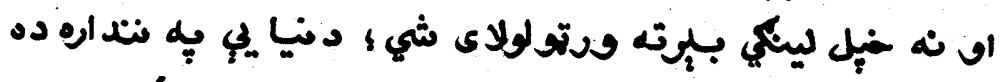

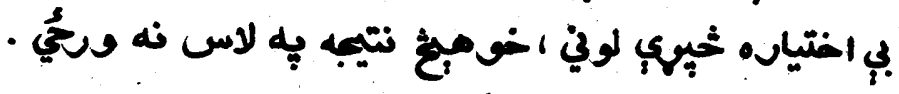

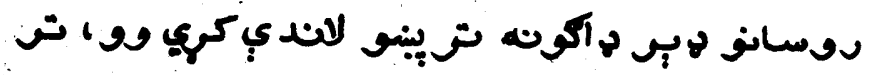

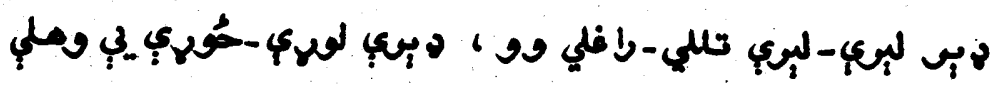

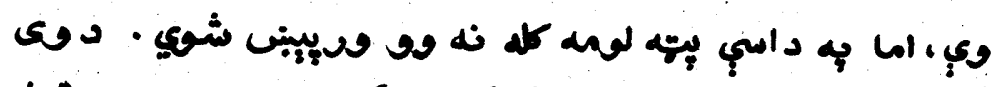

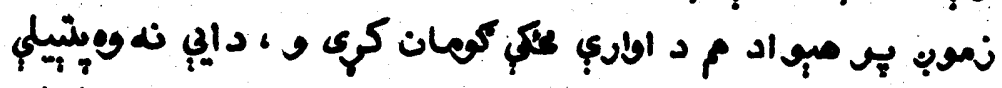

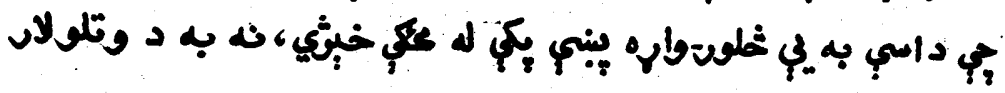

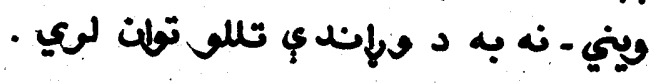

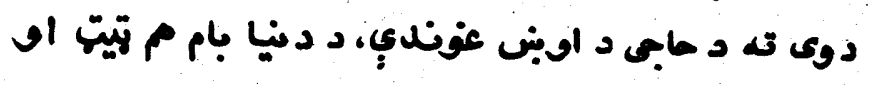

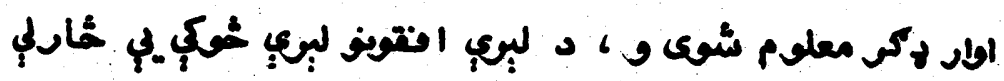

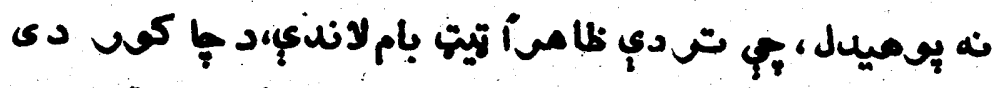

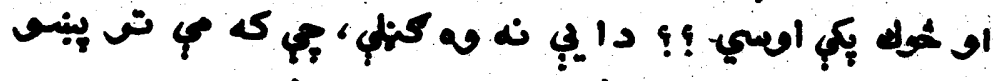

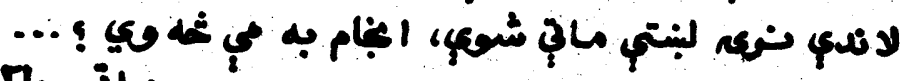

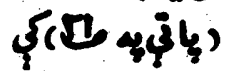




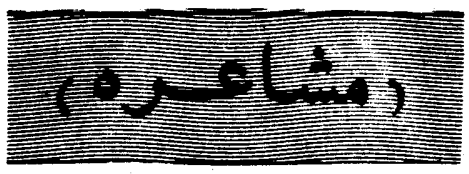

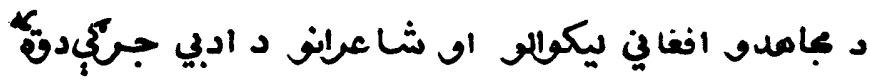

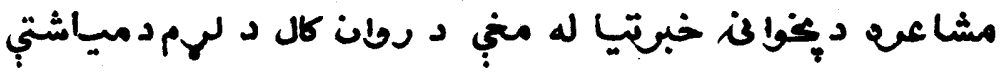

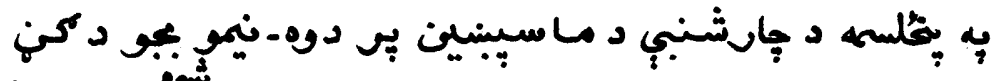

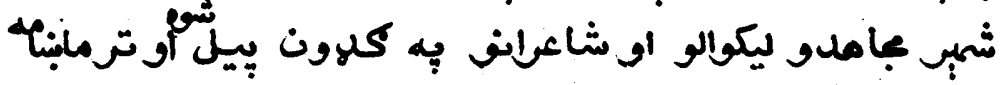

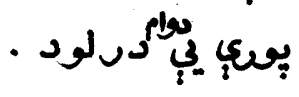

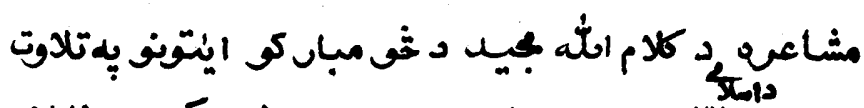

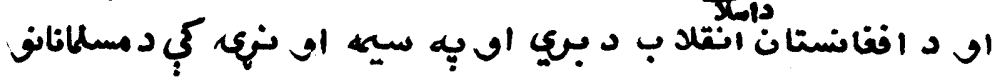

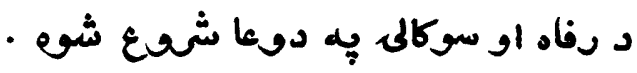

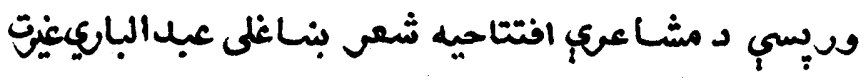

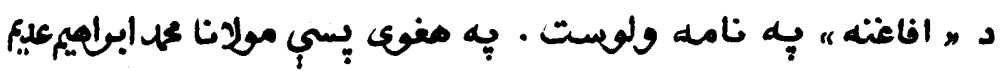

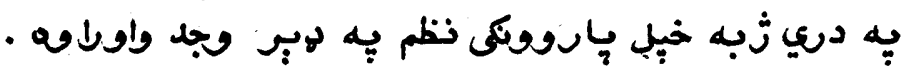

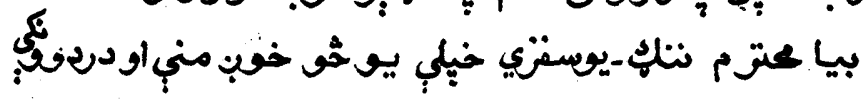

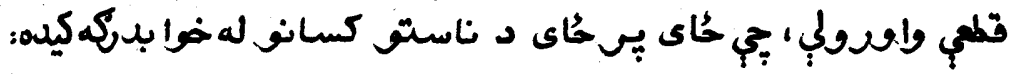




\section{مشاعرن}

$9 f$

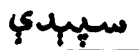

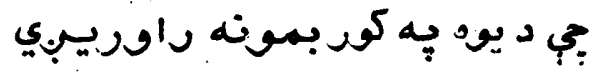

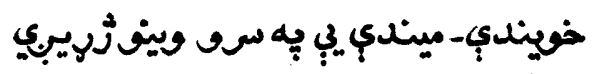

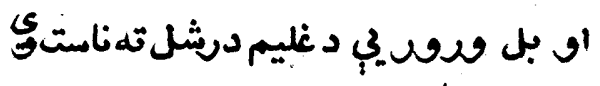

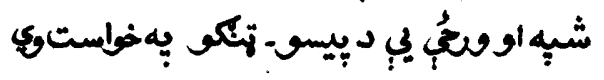

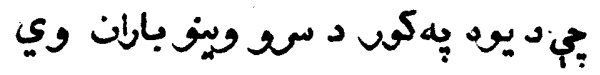

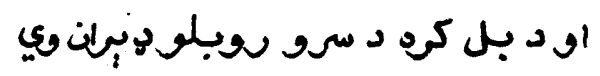

نو : نو :

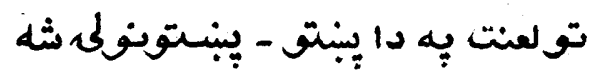

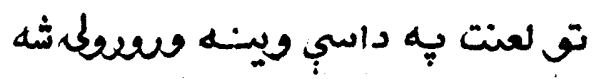

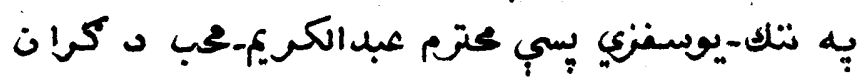

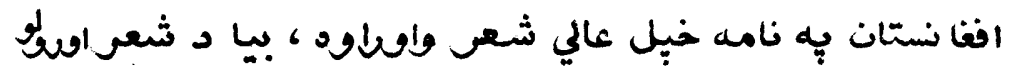

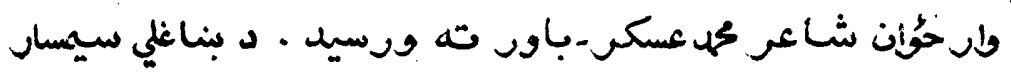

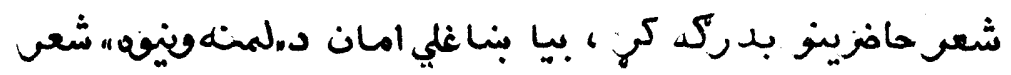

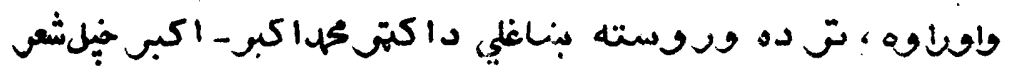

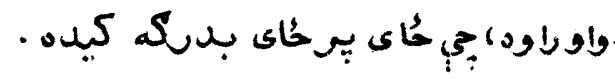

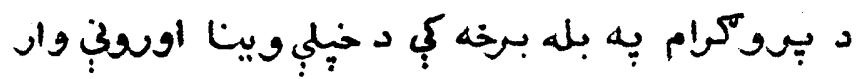

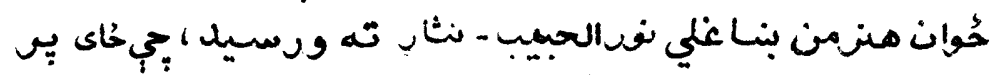

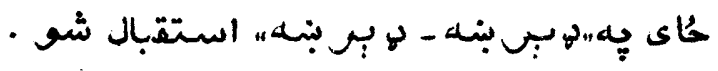

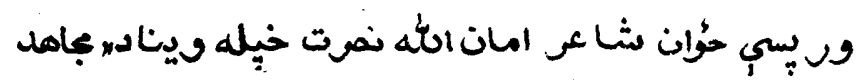

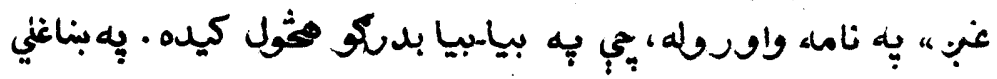

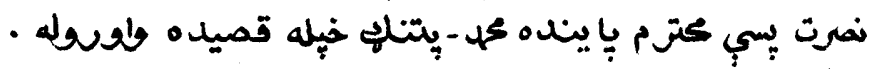




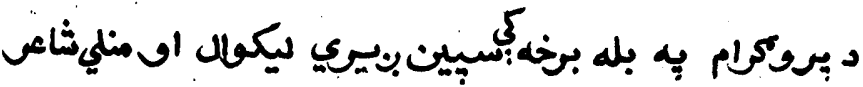

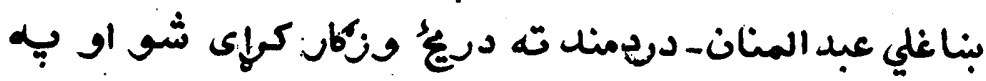

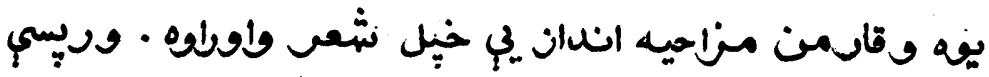

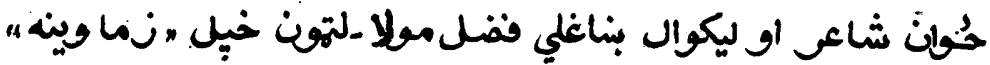

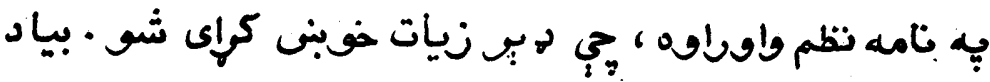

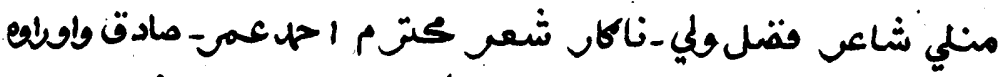

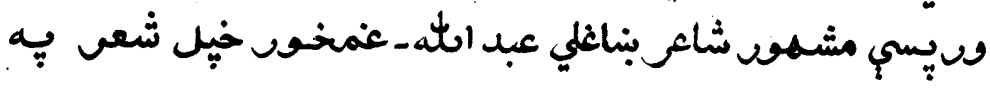

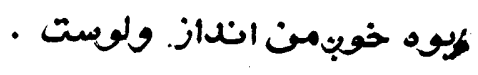

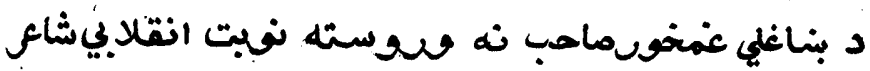

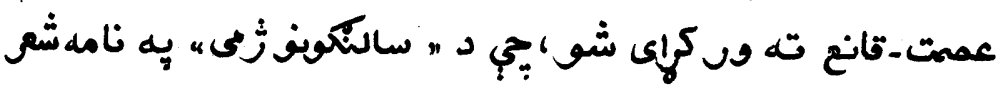

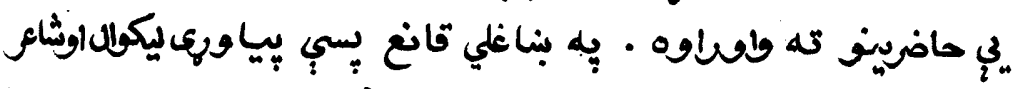

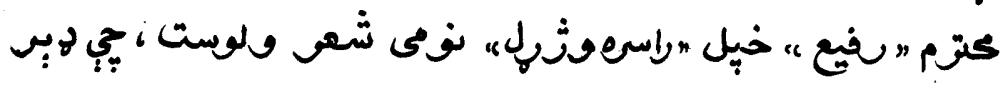

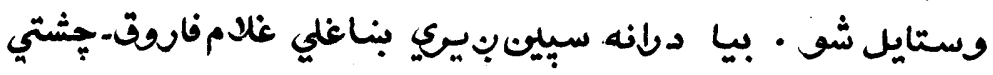

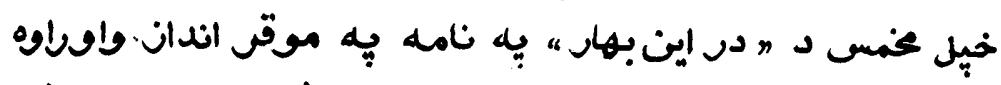

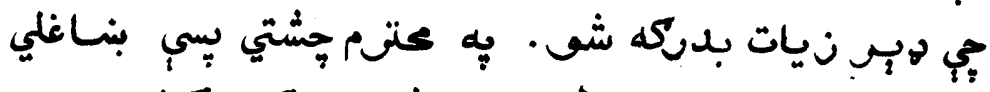

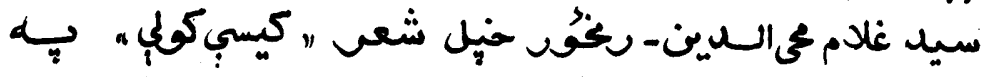

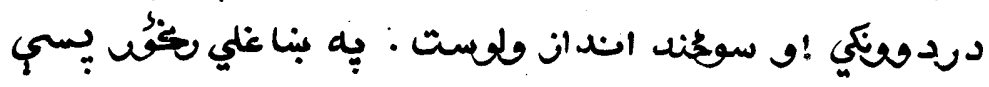

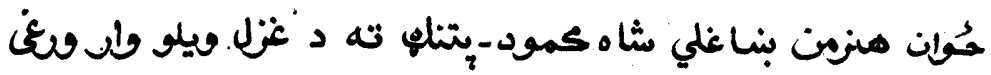

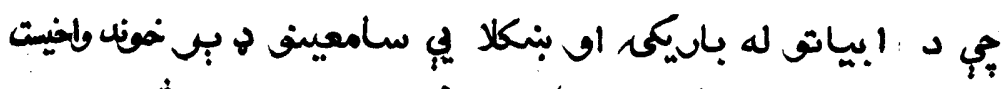

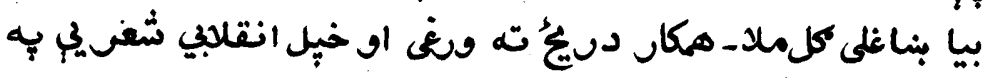

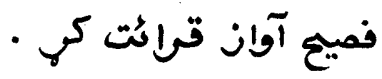




\section{ancling}

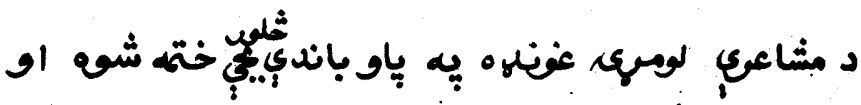

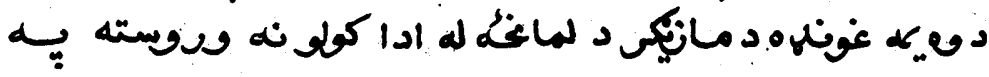

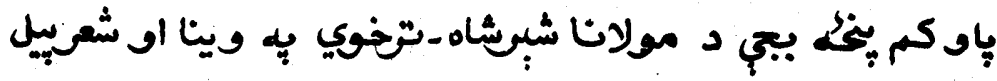

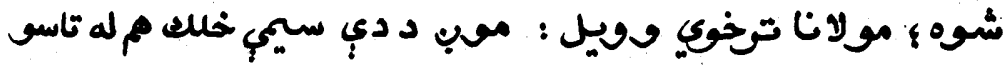

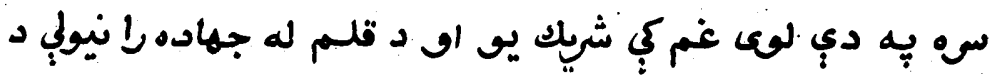

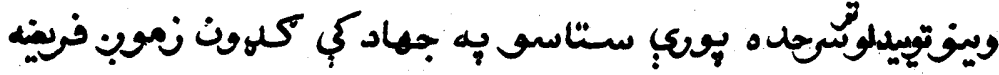
اونجينه ده -

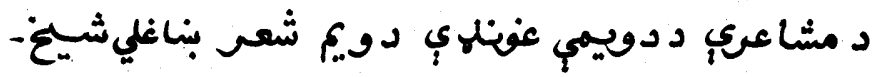

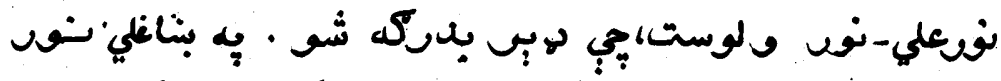

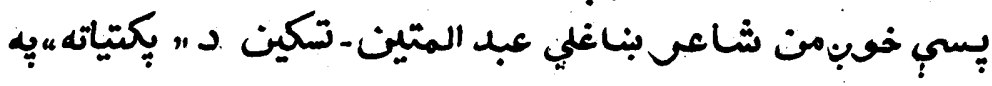

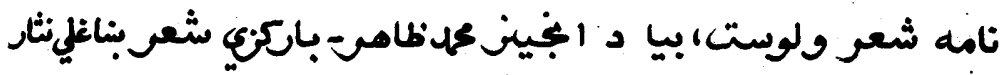

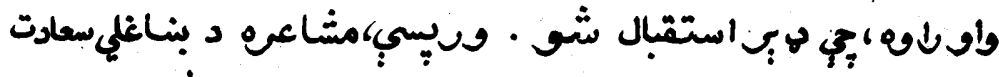

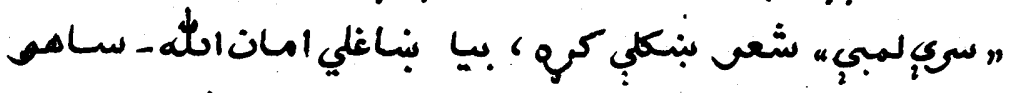

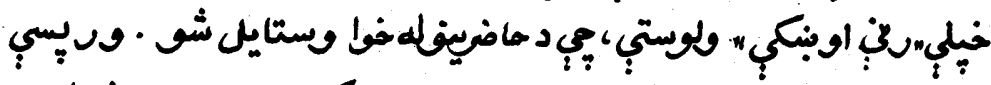

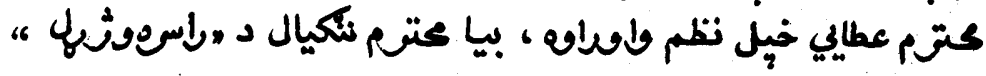

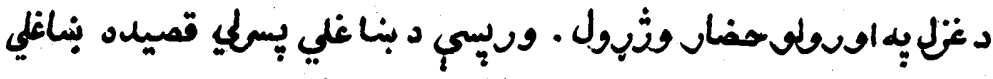

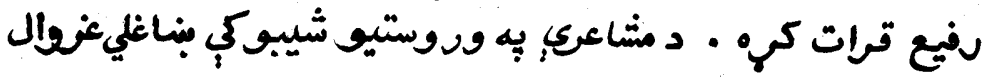

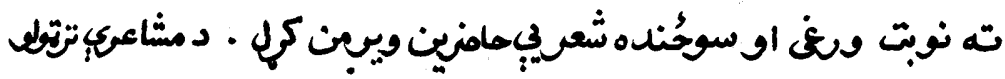

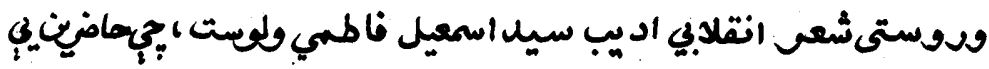

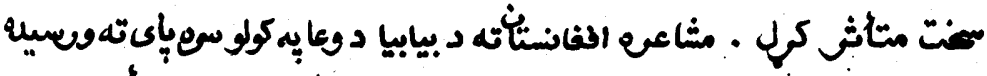

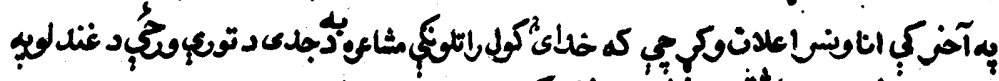

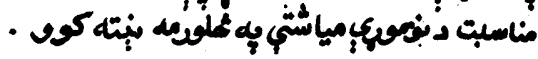




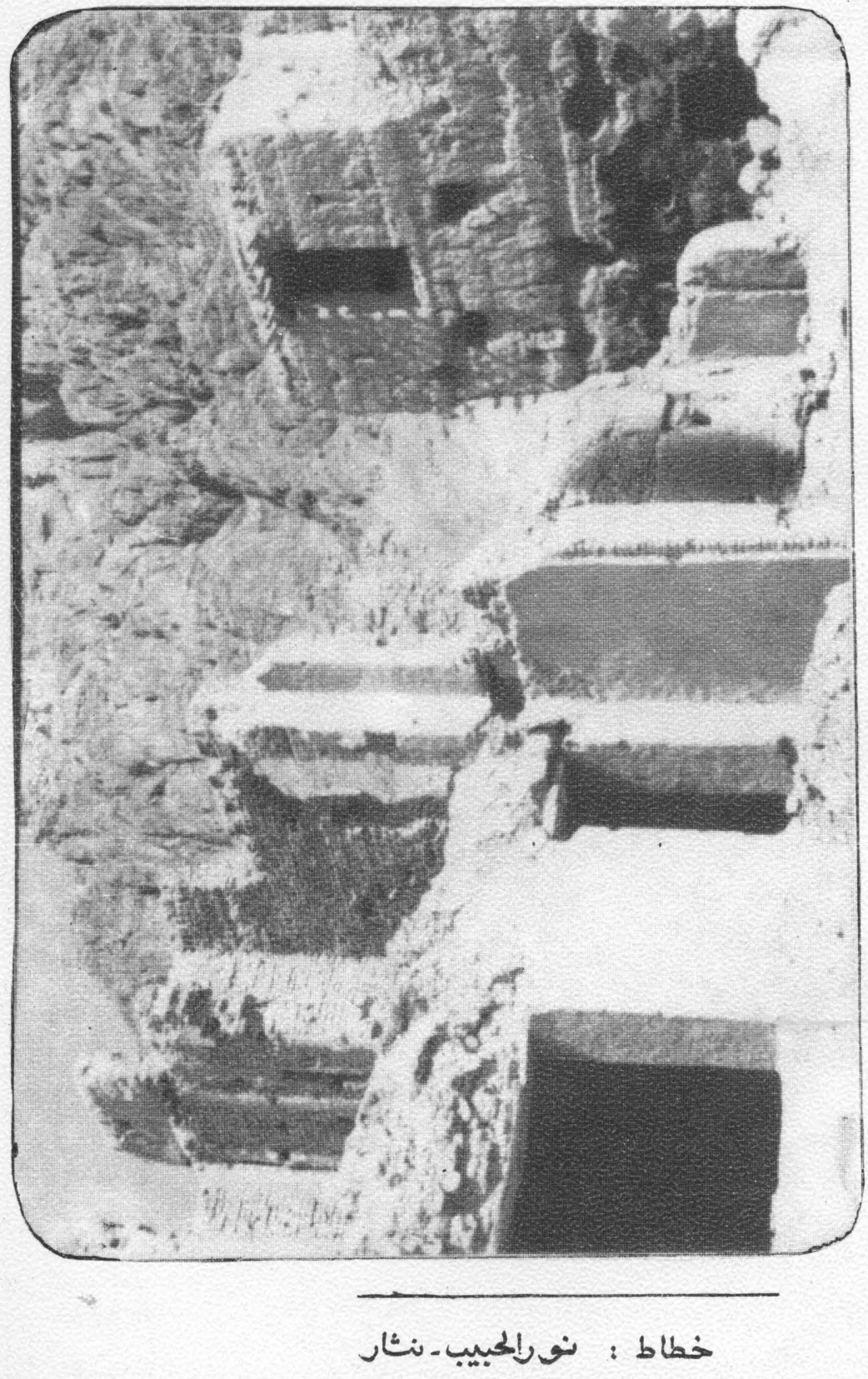




\section{Monthly}

\section{SPEDE}

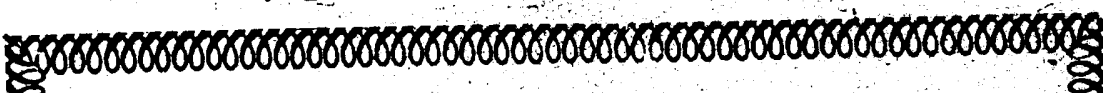
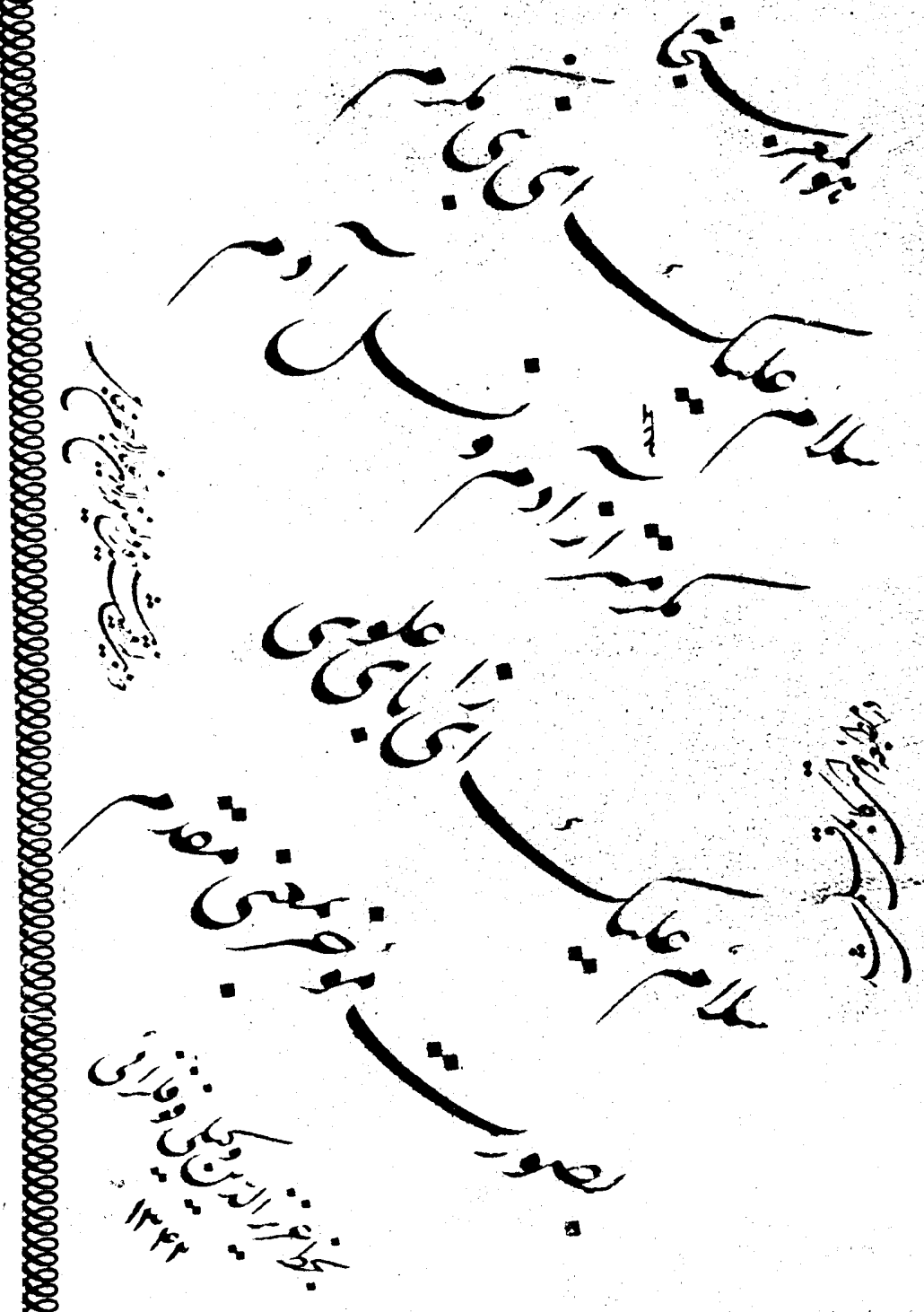